

\section{Smithsonian Institution}

Smithsonian Ihstitution Sibraries

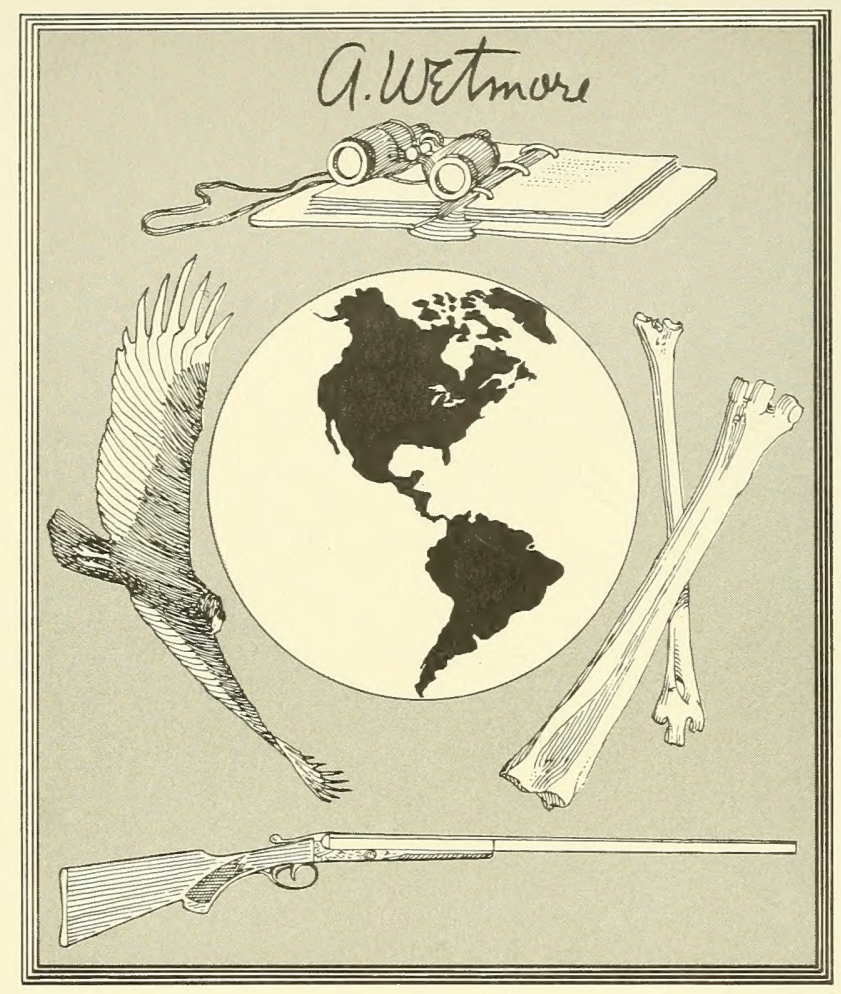

Alexander Wetmore 1946 SixthSecretary 1953

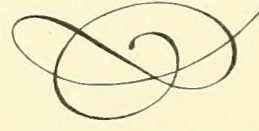







\section{6hal Mentaic \\ A

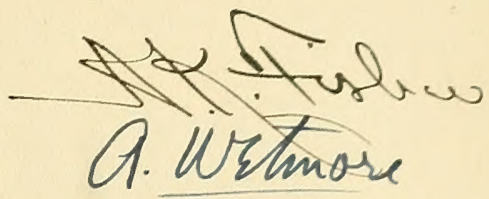

MANUAL

OF

\section{ORNITHOLOGY.}

BY

WINFRID A. STEARNS.

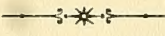

Being a Preliminary Study of the Classes, Orders, Families, Sub-Families, with an enuMERATION OF THE GENERA AND PRINcipal Species, of the Birds OF NORTH AMERICA.

Together with a Brief Synopsis of the Special Features of General Ornithology.

DESIGNED FOR THE STUDENT AND ALL LOVERS OF THIS MOST FASCINATING BRANCH OF SCIENCE. SUITABLE ALSO AS A SIMPLE, PRELIMINARY INTRODUCTION TO ANY OF OUR PRESENT WORKS UPON THIS SUBJECT.

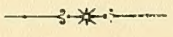

1895.

PRINTED FOR THE AUTHOR

AT THE ATLANTA UNIVERSITY PRINTING OFFICE,

ATLANTA, GA. 
COPYRIGHTEE. 


\section{DEDICATION}

.000.

TO ALL WHO ARE BEGINNING THE STUDY OF THIS MOST DELIGHTFUL SUBJECT. 



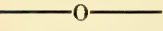

HAVING searched in vain for more than thirty years for a simple text-book to assist in the study of general - and especially North American - Ornithology, the writer has decided, at leugth, to make one for himself. The work was planned some years ago; and the following letter was written in answer to a communication anticipating, in a great measure, these very pages, and will explain itself:

"Wood's Hole, Mass., June 17, 1871.

Mr DeAR Sir :

Your letter of the 6th has been forwarded to me from Washington, and in reply it gives me pleasure to authorize any use you desire of the material published in my work on the Birds of North America.

I shall, of course, be gratified to have you make whatever acknowledgment you may think best of the service which you consider that this may have been to you.

Very truly Yours,

Spexcer F. Batrd."

iv. 
No one would attempt to study BIRDs successfully without ultimately referring to the works of this great man. Much of his material has been found a valuable help in the preparation of these pages.

The works of nearly all of our well-known writers of today, that were available, have been consulted, also, that nothing essential to a clear exposition of the subject might be omitted.

I shall hold myself personally responsible for the material alone of which this work is composed, and not for typographical errors discovered too late to remedy them.

Winfrid A. Stearns.

Atranta, Ga.,

July 1, 1895. 


\section{N T R O D U C T I O N.}

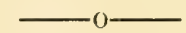

WE had penned "The History of Ornithology" as far as the name of GARROD before seeing a somewhat similar arrangement of Boldface type, for the name and date of the author, in the Encyclopcedia Brittanica. The system appears to be too useful to change, just because so excellent an authority has also employed it. The Ornithological Specialist will, doubtless, regret the briefness of the biographical references given under each name; but we are writing for the Ornithological Student, who will, we hope, be pleased at the omission of technicalities which would hinder rather than assist him. A wise teacher will know at once what lines to pursue in this investigation; what portions may be used in the class room, and what to omit. The advanced student can judge for himself how to use the material here suggested rather than fully presented. The main text is intended as an introduction to general Ornithology, and to the study of individual species. The Glossary follows as a necessary explanation of the various terms employed in the previous parts. 



\section{THE HISTORY OF ORNITHOLOGY.}

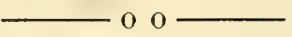

WHEN a writer attempts to present an historical account of some event or events, or a long procession of events, he must, of necessity, study deeply the writings of the chief actors in them. He does this, usually, in one of two ways - perhaps in both, namely : by investigating for himself the original writings, or by reading what persons of eminent authority in such subjects have said of them. The History of Ornithology and the Progress in Ornithology have been written and rewritten, both wholly and in part, times without number. I do not seek to do anything new in endeavoring to present a brief account of the principal actors upon the Ornithological stage, but wish simply to bring together, as far as seems necessary for our present purpose, an intelligible, brief history of the principal changes and additions as they have combined, to the present time, to give us the classification which we employ to-day, imperfect as it is.

To name all the different systems of Ornithology which 
have appeared from time to time, during the past few centuries, would make a volume almost in itself. Our intention is, in the main, merely to indicate the proper lines of study which one might pursue with advantage to beeome familiar with its history. It is more to assist the student than to furnish him with complete information.

The progress which Ornithology has made, from its earliest inception until the present time, is very similar to that made by any of the kindred sciences. Each has begun with the lowest ideas of the real relations existing between men and things; and each has advanced, as rapidly as the spirit of the times would admit, to its present standpoint. All along the line, however, have appeared special departures, as one might call them. where the old thought was left for, or incorporated in, a new and generally more complete one. These departures have been, for the most part, so radical, and so noted for their truthfulness to nature, that the men who conceived them were and still are mentioned as masters in their departments. We note the progress of any great event more by the brilliant light which genius casts upon it, as if by special revelation from the unknown to the kuown, than by the petty wranglings of jealous rivals. Truth always clears itself in the end. No part of it was ever lost to the world through want of the means to spread itself abroad. When the mind of man is prepared for its reception, it will appear in all its beauty and fullness, and harmony of law, - until then we have but faint and disconnected glimpses of it only. A master mind will collate the disjointed thought and embody it in a grand harmonious expression of some vital, living Truth.

Let us look briefly at this Progress of Ornithology as history furnishes it to us: And here, as in other sciences, we can justly begin with the old Greek philosepher Aristotle, who was the first to give us any very definite conceptions of Birds, - but, though he separated the species and recorded their habits with considerable fidelity, his ideas were crude when viewed from the standpoint of our present understanding of 
them. He tells us, for instance, that "some are carnivorous, others granivorous, and others omnivorous; some are terrestrial and some aquatic ; and many migrate during the winter." This is good as far as it goes, but it does not go far enough. His "Perr Zoon 'Istorias" is full of practical suggestions and pleasing information. He was followed by Pliny [the elder,] who was rather a compiler than an original thinker and observer, though he filled several volumes with both compilations and original observations. It seems hardly fair to accuse him of a lack of originality in his work, though it be true, when it is remembered that he lost his life while investigating a volcanic eruption of Vesuvius. Pliny [the younger], is really an observant naturalist, though he tells a great many "fish stories." He amuses us with his account of the Ostrich, and says: "Their Hoofs are like unto Stags, with which they fight or skirmish, being cloven-footed, they are profitable to them by laying hold of stones which they throw with their feet against those who follow them in flight." He also says: "The first distinction principally is made from the feet of Birds. For either they have hooked talons, or claws with nails, or are of the kind of having their feet closed with a film or web, as the Geese, and almost all aquatic birds. Those which have hooked talons only for the greatest part feed on flesh." A curious and interesting extract is the following, refuting the credited authority of to-day for this established "sub-order Oscines;" it will be seen from this that Pliny THe younger and not Dr. Cabanis is the proper definor of this division. He says: "these birds which have crooked claws, do not at all assemble together, and which prey on themselves. And almost all of them soar or fly on high except the nocturnal or night birds; and the larger birds the more so. They have all of them large wings, but a small body. They walk with difficulty. They seldom stay on rocks, the crookedness of their claws forbids it. Now we will treat of those according to a Second order, which are divided into two species, the Oscines and Alites: the first of 
them, the Oscrnes, have a kind of singing, chirping, or the like, the latter, such as Eagles, a magnitude hath given a difference to these. And so they proceed according to order." Pierre Belon, 1551-53, who may really be called the founder of Ichthyology, gives us our first really reliable information regarding the habits and lives of Birds, - yet his attempts at a classification would simply amuse us now, as for instance: "the rapacious birds form the first division, the waders the second, the swimmers the third, and the birds which nestle in trees or on the ground the fourth." This last division does not seem so absurd when we recollect the ancient belief that water birds built nests which swam upon the water wherein they laid their eggs and reared their young; also, that as late as 1633 the common goose-necked Barnacle was supposed to bear within it the young of the Wild Groose. For all this, BeLon was a careful student of bird anatomy. Many of the later naturalists regard his works with favor, and even the eminent BuFfox quoted him frequently. About the same time with BeLox, though a little later, appeared Conrad Gesner, 1585, whose work was hardly more than a compilation from the works of all of his predecessors, yet he was highly esteemer in his day and by many even now for this very reason. Text appeared Ulysses Aldrovandi Aldrovandus, 15991640. He is more frequently called by the latter name. He was said by many to be the greatest naturalist of his times. Three volumes of a work on Ornithology, with the classification of BELox, and many new descriptions, treat of the sulyject in a very interesting manner. He was a great traveler, and appears, to some extent, in nearly all of the sciences; but no real advancement in our knowledge of Ornithology seems to have been made until Francis Willoughby, 1678, and after him John Ray, 1720, appeared, and gave scientific form and accuracy to the hitherto scattered thoughts upon this great theme. Both were Englishmen; both companions and tratelers. WiLloughby conceived the idea of a general work upon all known animals and plants. He labored hard, and, 
being rich, successfully for his time. With him appear the first gleams of systematic classification. He divides Birds into Land Birds and Water Birds, and each of these divisions are separated into sub-divisions. His work was one of great merit. He died without publishing his volumes and his friend RAY saw them through the press. RAY then continued these subjects adding his own investigations; he, also, died withont publishing his results, these were published by

\section{Dr. William Derham, 1713}

We come now to a lull of nearly a century in Ornithological writings, when the master mind of LiNNжus appears. Carolus or Charles Linnæus was a Swede, born at Rashalt May 24, 1707, and he showed a remarkable fondness for Nature from a very early age. His way was full of difficulties, but he persevered, and the light which his genius threw upon science claims for him a position which will ever remain an exalted one. The divisions which be established were based upon form, and all those external and striking peculiarities even now make so prominent by many observers, and were as follows: Accipitres, Picm, Anseres, Grallet, Gallines, and Passares. These orders were almost entirely characterized by the shapes of the feet and of the bill. Linnæus' works ran through many editions. The twelfth, 1766, was his last. The thirteenth, 1788, was compiled by John Gmelin. It might, even now, be justly called in question as to which of the two were the better and more perfect. But the spirit of Linneus had cast its spell over a subject which was, thenceforth, never more to remain inactive. M. T. Brunnich, 1754-63, wrote extensively upon Ornithological subjects, though he gave us no definitely improved classification. He was of Danish extraction. Mark Catesby 1754-71, ranks high as an original investigator in our colonial Natural History. He described all that he could find of interest in our South-eastern Atlantic States. M. J. Brisson, 1763-69, proposed a classification based upon "the toes and their membranes, the bill, and the feathers of the legs." $\mathrm{He}$ 
emphasized " descriptions and illustrations," and noted 26 orders and 115 genera, and more than 1300 species of birds. Jacques Schæffer, 1764, also proposed a system, he principally " divided birds according to their feet." P. S. Pallas, 1767-80, published a work called Spicilegia Zoologica, which, with his other Ornithological writings, gave him great renown. He belonged to what is called the Linnear School, and described species rather than presented new classifications. Then the Count Buffon, 1770, gave us, without classification, his then famous popular bird-biographies. The name of J. R. Forster, 1771, is often quoted as an Ornithological writer of repute, but more as a describer of species and a compiler than as a systematic classifier. After Fonster a very important classification was proposed by J. Ant. Scopoli, 1777, based upon the "reticulation, scutellation, etc., of the tarsal envelope." The name of Thomas Pennant, 1776-92, was a household word one hundred years ago. He was an Ornithological as well as a literary giant in his day. He is still a peer in "Aretic Zoology," and especially in Ornitholngy. His classification was followed in later years by Alexander Wilson.

We are often indebted to the Germans for some of our best technical scientific discoveries. In the science of Ornithology this is also true : and now a German, Blasius Merrem, 1786, hands down to us a very important factor in our systematic classification, by bringing into prominence the shape of the sternum: the "Aves CARINATE" having it prolonged and keeled, and the "Aves RATITæ" having it flat and smooth. These distinctions, first made prominent, were afterwards used only as minor, though none the less interesting, features in the formation of the higher divisions. Just why the peculiar arrangement of Birds used by Dr. Joinn Latham, 1782-99, should have received so much attention, both at the time and even to within quite a late date, does not readily appear. He used, in the main, the system of Lincacs with a few corrections and additions of his own, and his general classification, 
now almost worthless, was followed by writers fir over a century. Latha w was an Englishman. He laid a very ereditable basis for a description of the Birds of the World, and divided them into 9 orders, ( 6 of LAND BIRDs and 3 of WATER BIRDs), 111 genera, and described over 4300 species; this was something magnificent for those days. The Abbe Bonnaterre, 1790, of whom we know very little, yet gave us very valuable additions to our classification. He proposed 12 classes and 112 genera "according to the form of the bill and other minor distinctions." Several of his suggestions were made abundant use of by later writers. W. Bartram, 179199, followed closely after CATwsBy, and their names are intimately associated. They pursued a parallel course of studies. B. S. Barton, 1799, followed Bartray and Catesby, but most of the writers since Dr. Lathan's time were species discoverers and describers, and pleasing writers rather than systematists. At this same time the eminent $\mathbf{M}$. de Lacepede, 1799, presented a classification for Birds making the FEATHERING or BEARNESS OF THE TARsus and the WEBBING OF THE FEET AND TOES his basis, - he separated Birds into two great groups accordingly. The general character of the orders remained unchanged. His system was a great advance towards modern classification. William Lewin, 1801, classified and arranged the Birds of Great Britain, though after Dr. Latham's plan. Ornithologists of to-day do not appear willing, it seems to me, to ascribe to poor La Vaillant, 1801, his proper due. The work which he did for this science, American as well as African, was simply tremendous; yet he died poor, and gave to others a chance to reap where he had sown. The Frenchman F. M. Daudin, 1802, published a work which became more popular, probably, than its author had ever anticipated. Constant Dumeril, 1806, in his Zoologie Analytique, put forth another system, but it soon gave place to that of J. F. Blumenbach, probably about 1804, who gave us a classification more nearly corresponding to that of DR. LATHAM than almost 
any which had appeared since the latter's time. It bears the author's personal impress, - and is still worth being referred to as an evident sign of progress by revertion to a previous classification with emendations to date.

Alexander Wilson, 1808-14, published his North American Ornithology, that noted exposition of the Birds of North America, just previous to the master work of AuduBon. Originally there were nine volumes, of which the last two were completed by ORD. WILson pursued the classification of Pennant. His work ran through several editions. Later several writers of note published their own revisions of it, especially Bonaparte, Jameson, Jardine, and the late Dr. T. M. Brewer. If Ornithologists of to-day would emulate more the example of this last careful, honest, honorable, and painstaking Christian gentleman, there would be much more knowledge of ou Birds, and much less of some writers and of their too evident compilations put out under the guise of original matter, abroad in our land. Both WILSON and AUduBon studied Birds not Books. As a result they are still quoted as authority in most Ornithological matters.

Dr. Geo. Shaw, 1809-12, was another writer who reverted to a former author for his system of classification, and he copied extensively from Linneus; on the other hand J. F. Stephens, who compiled the latter part of Shaw's General Zoology, really thought in advance of his time by anticipating many of the changes of later writers, - yet, on the whole, it is doubtful if his views were credited to him with the same generosity with which they were credited to those who followed out many of his ideas. Messrs. J. Wolf and B. Meyer, (1810,) two German scientists, now revived the idea that Land and Wuter Birds were the two great classes which separated, most successfully, the species, and they further furnished a somewhat new arrangement of 9 orders of the former and 2 of the latter. The Oscixes, though the division was much more limited as to the species comprised by it than at present, were brought into prominence largely through their means. 
Still another German, J. C. W. Illiger, 1811, now became prominent, and his work stands next to that of LINNEUS, in point of time, as regards scientific accuracy and value. $\mathrm{He}$ brought together the results of all his predecessors, and attempted, successfully, a new departure as a basis for future advancement. His idea was of a system which should recognize more close affinities than had hitherto been apparent of Birds with each other. He did this by introducing the FAmILY as a sub-division of the Order. His system gave us not always the most perfect but, to the eye perhaps, the most natural, arrangement. Of his 7 orders the 1st, The Scansores or Climbers, contained 5 families; the 2nd, The Ambulatores or Walkers, 11 ; 3d, The Raptores or Birds of Prey, 3 ; 4th, The Rasores or Seratchers, 5 ; 5̃th, The Cursores or Runners, 3 ; 6th, The Grallatores or Waders, 8 ; and 7th, The Natatores, or Swimmers, 6. Through ILLIGER the idea that all Birds were more or less closely allied to each other by such characteristics as would separate orders into families, and families into still smaller divisions, until ultimately individual difference, embracing within it order and family itself, began to dawn upon the mind of scientists. Closely following ILLtGer came the Baron George Cuvier, 1817, with his great work La Regne Animal. He was a man whose erudition is still the envy of the world. His work was preeminent in its day. The great majority of writers who preceded, as well as those who have followed, him have fallen far below his worth and penetration. Cuvier and Linneus go hand in hand, - the former correcting the ostensible and real errors of the latter. The basis of CUviER's classification has been followed almost universally by the thousands who, since his day, have revelled in the broad field of Nature's creation. His special tribute to the chain of Ornithological classification which we are seeking to examine were investigations upon the MUSCULAR ANATomy of Birds. He made prominent the singing muscles of the larynx, by which we separate the Insessores into the Oscines or Singers, and the Clamatores or Screamers. He made 
many important changes besides this. It was a great advance in our knowledge of the systematic relations of Birds. Next comes M. P. Vieillot, 1817-23, really 1805-23. His labors were noted for their descriptive value. He published a great deal, and, as he sought to popularize the science, his works proved very attractive and became quite widely known. C. J. Temminck, 1820, at the time Curator of the Royal Museum at Leyden, then brought out his noted Manual of Ornithology, the second edition of which appeared at the above date. It contained an analysis of general Ornithology, and his arrangement of the different classes of Birds - which was essentially a new one. It was for a time recognized as an authority, but being mainly a compilation from previous writers soon gave way for newer matter. He wrote a great deal besides this, praising IlLiger but deprecating VieILLOT. L. Oken, 1821, was a German Ornithologist of great note. He added a great deal to our knowledge of Birds. A treatise of his published in 1809 really foreshadows his maturer work in 1821. He speaks of "birds that are fed by their parents and those that run about at birth" in such a way as to leave no doubt but that he outlined our present division into ALTRICEs and Precoces. Somewhat later his work was taken up by Ehrexbura. John P. Selby, 1821-34, is another excellent writer who sought to popularize British Ornithology by his elegant volume. It was the best effort of his time and approached by few. Conjointly with Sir Wm. Jardine, he published several raluable works and many detached writings upon this subject. The latter conducted that eminently popular and intensely interesting series entitled The Naturalists' Library. R. P. Lesson, 1822-34, was a most voluminous writer whose works were constantly appearing. He seems to have both adopted an old and created a new system, - but there seems to appear no special marks by which to show that any really new material became incorporated into the great fabric of our present classification. After Lessox there came C. L. Nitzsch, 1829. He introduced the "CAROTID COM- 
MUNes," and described so definitely the "forms and positions of this artery" as to fully establish it as an evident factor in our present classification. William Swainson, 1827-31. Mr. SwaInson probably did more than any other writer in his time to popularize science. His name is connected with many volumes upon many subjects. He was a careful and accurate naturalist. He prepared the greater part of the second volume of Arctic Zoology, that on Birds, for the careful execution of which he is specially known among Ornithologists, in convection with Dr. John Richardson, who prepared volumes one and three of the same work.

The name of John James Audubon, 1827-31, marks a new Ornithological epoch. His efforts to give to the world a thoroughly reliable account of the Birds of North America will ever remain unique. These efforts produced " 5 octavo volumes of text and an elephant folio atlas of 4 volumes of 435 plates:" The ordinary "Audubon" of to-day is not this, however, but a smaller edition of 7 volumes which has sprung from it. In a small single volume, his Synopsis, he sets out his views regarding the general classification of the Birds of which he speaks, although, as he there states, "the location of the groups is not such as, in all respects, to satisfy me." He studied deeply the ANATOMy of THE Digestive oRGANs of Birds, and introduced it as a new feature into his various groups.

Jan Van der Hoeven, 1828-33, [revised edition, 1849. 50,] was a voluminous writer, and is still a favorite with many for his apparent definiteness of general classification; but it is mainly a compilation, not always of the latest facts that might have been obtained at the time, from previous writers with very little original new matter; yet this was a better text book of general Zoology than it was at the time, or even now is, credited with being.

Thomas Nuttall, 1832-34. This searcher apparently after the same object as incited both AUduBon and WiLson raised himself to eminence by popularizing his subject and reducing 
the price of his volumes, of which he published two - one of them on the Land Birds and the other the Water Birds. His second edition of this work was a much more creditable one than the first. The recent revision of it by Mr. Montague Chamberlain makes it, now, a most valuable and truly delightful book for all Bird lovers.

C. J. Sundevall, 1835-56. We are indebted to this distinguished Swede for a departure which gave to the classification of the present day a most decided feature. He crystallized the hints of OKEx and the maturer judgments of EHREnberg by his definition of the groups Altrices and Prcecoces, and of the Birds which belong in each. These groups are often regarded as of SUndevall's own creation. This is hardly true in view of the previous definite statements of the two gentlemen above named. Most of his work remains today as much of an authority as when he wrote it. Ornithologists still follow closely his classification, and he is liberally quoted, though essential features of his work are being modified by later authors who are leading writers in this and other countries. He also made prominent the details in the use of THE WiNGS AND THEIR coverts to separate his groups. C. G.

Ehrenberg, 1836, worked in harmony of thought with OKEN, and the two are usually mentioned together. The latter explained and solidified the work of the former. William MacGillivray, 1836-52, was a Scotchman, whose Histories of British Birds and Mammals has rendered his name famous in this country as well as abroad. He was much esteemed by AUDUBOn, whose spirit of equity would justify to him a title to accuracy and reliability. We cannot lightly pass over the important labors of G. R. Gray, 1837-49, whose Genera of Birds, as issued from the British Nuseum, as well as his other Ornithological writings, though following CUviER largely yet with many important changes of his own, still forms, revised, a very important source of reference even to-day. His system was, howerer, much improved a little later by Vigors. N. A. Vigors, 1829-39, whose work centers about this period, 
wrote chiefly detached papers upon special subjects, but for clearness of judgment and depth of thought he obtained through them a wide eminence. The systematic ending of family names in IDE is attributed justly to him. He formed a classification to suit himself and it was a good one, hoping, as so many of his predecessors had done, that he had established the true relations between Birds. He joined what had before been styled the normal and aberrant groups, and, taking the formation of the foot for CLASPING or NON-CLASPING as a basis, he changed the order of the orders so that the Raptores and the Insessores comprised the former, and the Rasores, the Grallatores, and the Natatores the latter. He has been much noted by Ornithologists of the present day for many advanced ideas; but his system still failed to establish permanent "typical" forms. Messrs. A. G. Keyserling and J. H. Blasius, 1840, are names generally associated together, although much good work was done by each individual separately. They really first presented us with an extensive use of the TARSAL COVERING and its various modifications as we now employ them in our descriptions. The scheme was afterwards elaborated by CABANIs. Two other gentlemen now formed a valuable combination, investigating in a new field, these were P. J. Van Beneden, 1845, and Carl Vogt, 1851. Both were active in promoting those EMBRYOLOGICAL investigations which are now so generally adopted, and which were so fully and so clearly set forth by L. Agassiz. J. Cabanis, 1847, has really assisted our classifiers more than many are willing to acknowledge, though a great deal of the new material which is credited to him is, in reality, the property of those who came previous to him; thus he really perfected much hitherto rudimentary knowledge. He incorporated into his system the various markings of the TARSAL ENVELOPE, and added to them the gradations in size of the principal PRIMARY QUILL FEATHERS of both the wing and of the tail. He also used the characters of the "IARYNX INFERIOR," said to be borrowed from Muller, a Danish naturalist. We owe 
him a debt of gratitude in assembling and perfecting the special characters brought forward by so many previous authors, and giving to us the whole in one continuous, comprehensive combination.

We next come to Charles L. Bonaparte, 1850-57, who was an ardent enthusiast, and clearly stamped his opinions as regards obscure points in our classification. He proposed a system, which, though it added few new phases to those already possessed, embraced faithfully the best suggestions of previous writers upon the subject. It was regarded, both at his time and for a long while after, in very high repute; and from the number of species then known to science of extensive scope. It was used by the best writers of the time in preference to the system of either Linneus or Cuvier. His name, though generally associated with that of WILson has, however, a wide significance of its own. John Cassin, 185355, really supplemented the work of AUduBor by his histories of Birds, for the most part those west of the Rocky Mountains. He also wrote a part of that fine work, The Ninth Volume of the Pacific Railroad Report, conjointly with Professor S. F. BAIRd and Mr. Geo. F. LAwrence. P. L. Sclater, 1857, et sec. and O. Salvin, separately and together, added their voluminous writings to the cause of Ornithology. The former has especially given us a very valuable basis for further definiteness of separation by his GEOGRAPHICAL REGIONS. He divided the world into a given number of these regions, and portioned to each its avi-fauna. These boundaries have been enlarged, from time to time, until our present wellknown "faunal regions" or "faunal areas" have resulted.

Professor Spencer F. Baird, 1858, was a gentleman deserving of more than passing mention. He was, for many years, the Secretary of the Smithsonian Institution, at Washington, D. C., and a most able writer and zoologist. From his personal ability alone he would very easily have lead the cause of Ornithology in America, if not abroad also. In his position as head of an institution such as the Smithsonian 
then was, he took that lead naturally; and the majority of writers since his day have largely compiled from him and his collaborators. He himself compiled largely: taking the best points from previous writers, he has added so many pertinent suggestions to his careful deductions from them that one can naturally and almost justly consider the whole matter as $\mathrm{Mr}$. BAIRD's own personal emanation. This is not done in any spirit of injustice to others, for no one was quicker in giving credit for any material which he might have used of another person's than was he; but his happy mode of presenting even the dryest technique makes one feel a master hand in all that he did. One is safe to be guided by the directing influence of the works of this truly great man.

J. C. Eyton, 1859-67, produced, to a large extent, the system which we very naturally look to Professor RicharD OWEN to adduce, namely: one based almost wholly upon the OSTEOLOGICAL characters of Birds. Its importance is manifest at a glance. It has entered largely into our later classifications, and in recent years become especially prominent. Professor Owen, Sir Richard Owen, 1866, used many osteological characters in a classification of Birds which he proposed, but its chief feature consisted in a radical transposition of the whole plan of arrangement as used up to this time; a putting of the lowest Water Birds first, and following this inverted order to the highest which came last, proved an innovation that became immensely popular at once, the more so as its appearance seemed to correspond with the recently largely adopted theories of evolution. It was something new, and had the impress of a great man. W. Lilljeborg, 1866, was a professor in the University of Upsala, Sweden, and himself a Swede. What he has accomplished as a student of Ornithology few have so far equallei. The basis of his structure was what he called "IRRITABILITY," or activity as we might perhaps better say. This, he contended, presented the fittest expression of Ornithological preeminence. On this scale he placed the Thrushes first. Our present system is but 
a modification of his most careful and excellent suggestions. Thomas H. Huxley, 1867, the eminent English scientist, in a system of Birds which he has tabulated in his volume on the Anatomy of the Vertebrate Animals, for the purpose of including the general field of fossil as well as recent Ornithology, has laid out a very comprehensive plan. He has combined and drawn deductions from former writers, changed many of the already existing relations of the characters, made prominent many osteological features, and taken for his two grand divisions the "Aves Carinatce" and "Aves Ratitoe" of Merrem. He has also added a few special anatomical distinctions. Admirable as this system is it is a system rather for the scientific student whereby to study relations than for the every-day working naturalist or bird-collector. The prominence still given to the groupings of Professor LiLLJEBORG speaks highly to its credit. A. H. Garrod, about this time, presented us with some very valuable features to add to our distinguishing characteristics between the various groups of Birds. He patiently worked upon the yUSCULAR relations, which had hitherto been of little import in classification. We are greatly indebted to him for his efforts in this direction.

The magnificent work of Baird, Brewer, and Ridgeway, it is safe to say, will not soon be duplicated; issued in five splendid volumes, it has really done for North American Birds a work of permanent good. It is both technical and popular, though rather expensive for the majority of students in this most fascinating branch of study. This work, with the individual Ornithological writings of these same gentlemen, has far out-distanced any modern competitors for Ornithological honors in America at the present day, at least as far as accuracy in scientific detail and reliability are concerned. Several very choice works upon Birds have appeared, from time to time, besides those we have mentioned above, some very recently, amongst which may be especially mentioned "Special Bulletin, No. 1," of the U. S. National Museum, entitled, Life Histories of North American Birds with special reference to their 
Breeding Habits and Eggs, by Captain Charles Bendire, and the various other National Museum and Government Reports.

One cannot examine the Ornithological writings of such men as D'Orbigny, Bechstein, Sclater, Salvin, Elliott, Gould, Tschudi, Hartlaub, Gosse, Cassin, Hudson, and a perfect host of others, who have described thousands of species, without wonder and amazement at the amount of accumulated new material from which to draw new deductions and even a newer classification, which shall be more thorough and more accurate in detail than any that has hitherto appeared. The present revertion of writers of the present day to the systems of LiLlueborg and of Sundevall is evidence of their depth of thought, boldness of design, and definite conceptions of the general relations of both the higher and the lower groups of Birds.

From the following selected List of Ornithological Writers write a composition upon, or short life history of, all or any of the persons indicated, and illustrate the peculiar manner in which they have become known to the world as Ornithologists. Give name, place and date of birth, nationality, date of death, and the most prominent and important works or writings of each. Arrange the names in three groups: 1st. Noted Ornithologists with a world-wide reputation as such; $2 \mathrm{nd}$. Those whose works are well-known and an authority, but who were not Ornithologists but men of eminence in other departments, often, who made the study of Birds a recreation or of minor eonsideration. 3rd. Those whose names and works are generally little known and rarely cited, except upon some technical or obscure historic point. Encyclopedias and works upon Biography and Natural History will be the means through which to obtain this information.

Agassiz, Louis, Aldrovandus, Ulysses, Bachman, Rev. John, Aristotle, Audubon, John James,

Bærii, Nichol, Baird, Spencer F., Barrere, Pierre, 
Barton, Benjamin F.,

Bartram, John,

Bechstein, J. M.,

Belknap, Jeremy,

Belon, Pierre,

Bewick, Thomas,

Blasius, J. H.,

Boie, F.,

Bonaparte, Charles Lucien,

Bounelli, Francois,

Bowditeh, Thomas E.,

Brandt, J. F.,

Brehin, Charles Louis,

Brewer, Thomas M.,

Brisson, Mathurin Jacques,

Bruch, Notar L.,

Bruụinich, Martin Thomas,

Buffon, Geo. Louis le Clere,

Cabanis, Dr. Jean,

Cabot, Samuel,

Cassin, John,

Catesby, Mark,

Cetti, Francesco,
Edwards, George,

Elliot, D. G.,

Emmons, Ebenezer,

Eyton, J. C.,

Faber, Fr.,

Fabricius, Otho,

Fleming, John,

Forster, J. R.,

Frankfort, A. M.,

Frisch, Jean L.,

Gambel, William,

Gatke, Heinrich,

Gerhardt, Alexander,

Gesner, Conrad,

Girand, J. P.,

Gloger, C. L.,

Gmelin, S. G.,

Gosse, Philip Henry,

Gould, John,

Graves, George,

Gray, G. R.,

Gundlach, John,

Hahn, Dr. Carl Wilhelm,

Cuvier, Baron Geo. L. C. F. D.,Haldeman, S. S.,

Daudin, Francois Marie,

Degland, C. D.,

DeKay, James E.,

Desmarest, Anselme-Gaelan,

Des Murs, O.,

Deville, E.,

Donovan, Edward,

D'Orbigny, A.,

Douglas, David,

Dubus, B.,

Dunn, Robert,

Dumeril, A. M. Constant,
Hartlaub, Dr. G.,

Haymond, Rufus,

Heerkens, G. N.,

Heermann, A. L.,

Holboll, Carl,

Hudson, W. H.,

Illiger, J. Ch. William,

Jacquin, J. F. E. von,

Jardine, Sir William,

Jenyns, Rev. L.,

Kaup, J. J.,

Keyserling, A. Graf., 
Kirtland, J. P.,

Kittlitz, F., H.,

Korner, M.,

Kuhl, H.,

Latham, Dr. John,

Lawrence, George N.,

Leach, Dr, William E.,

Lembeye, Juan,

Lesson, R. P.,

Lewin, J. W.,

Lichtenstein, Dr. H.,

Lilljeborg, Prof. W.,

Linnæus, Charles,

Linsley, Rev. J. H.,

MacGillivray, William,

Malherbe, E.,

McCall, George A.,

Merrem, Blasius,

Meyer, Dr. B.,

Moehring, P. H. G.,

Moschler, H. F.,

Muller, John,

Muller, O. F.,

Natterer, -

Nauman, J. A.,

Nauman, J. F.,

Newberry, Dr. J. S.,

Nilson, S. V.,

Nitźsch, C. L.,

Nuttall, Thomas,

Ord, George,

Pallas, Pierre Simon,
Peabody, Rev. W. O. B.,

Pennant, Thomas,

Ray, John,

Read, M. C.,

Reichenbach, Dr. Ludwig,

Reinhardt, J.,

Richardson, Dr. John,

Sabine, Captain E.,

Sabine, J.,

Salvin, ().

Savigny, Jules Cesar,

Schlegel, Prof. H.,

Sclater, Philip L.,

Selby, John Prideaux,

Shaw, Dr, George,

Sparrman, Andrew,

Streubel, A. B.,

Sundevall, C. J.,

Swainson, William,

Temminck, C. J.,

Thienemann, Dr. F. A. L.,

Thompson, Zadock,

Townsend, John K.,

Tschudi, J. J. von,

Vaillant, Francois C.,

Vieillot, L. P.,

Vigors, N. A.,

Wagler, J.,

Wied, Max Prinz von,

Willoughby, Francis,

Wilson, Alexander,

Wolf, Dr. J.,

Yarrell, William. 



\section{A}

\section{MANUAL OF ORNITHOLOGY.}

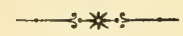

LINNAUS, the father of Ornithology as we know it, and the most modern of the older writers, divided all Natural objects into 3 KINGDOMS :

\section{THE ANIMAL KINGDOM II THE VEGETABLE KINGDOM III THE MINERAL KINGDOM}

We have to deal exclusively with the ANIMAL KINGDOM and but part of that.

There are, to-day, TWO SCHOOLS OF WRITERS upon the Animal Kingdom (as there are, also, upon the other Kingdoms) called, respectively, the OLD SCHOOL and the NEW SCHOOL.

Of the former were Linnæus, Cuvier, and others, whose work cannot be wholly ignored; of the latter are Huxley and the German naturalists, who have found able advocates, in this country, in Packard, Morse, Hyatt, and many others. 
The Old School divided the Animal Kingdom into 5 BRANCHES :

\section{VERTEBRATES \\ II ARTICULATES \\ III MOLLUSCS \\ IV RADIATES \\ V PROTOZOA}

The last 4 Branches, taken together, are called the INVERTEBRATES, in distinction from the 1st or VERTEBRATES. Thus we speak of the Animal Kingdom, as a whole, as being divided into 2 SUB-KINGDOMS :

\section{VERTEBRATES \\ II INVERTEBRATES}

The New School divides the Animal Kingdom into 8 Branches, and reverses the general order of their precedence, thus :

\section{PROTOZOA \\ II PORIFERA \\ III COELENTERATA \\ IV ECHINODERMATA \\ V VERMES \\ VI MOLLUSCA \\ VII ARTHROPODA \\ VIII VERTEBRATA}

Here the first seven Branches constitute the Invertebrates, as opposed to the eighth or the Vertebrates.

Some writers do not make a separate Branch of the Porifera or Sponges, but connect them with the Protozoa and, after the Mollusca, add the MOLLUSCOIDEA and the TUNICATA as of the same relative value as the others.

In either case we have to do only with the

\section{SUB-KINGDOM VERTEBRATA}

Both the Old School and the New School of writers unite in dividing the Vertebrates into 5 distinct GROUPS : 


\section{MAMMALIA OY MAMMALS \\ II AVES or BIRDS \\ III REPTILIA or REPTILES \\ IV BATRACHIA Or AMPHIBIANS \\ $\mathrm{V}$ PISCES or FISHES}

We have to deal only with the

\section{GROUP AVES or BIRDS}

The Birds of the World are separated into two great SLBGROUPS, - accoraing as the STERNUM OR BREAST-BONE: is FLAT or KEELED in front. [The extinct species, however, belong to other divisions]. They are, the

\section{AVES RATITAE}

(Latin ratis, a ratt). Sternum fLAT. Wings rudimentary and unfit for flight.

\section{AVES CARINATAE}

(Latin carina, a keel [of a ship]. Sternum keELed. Provided with true Wings.

The first of these divisions embraces the Ostriches, Cassowaries, Emeus, and Birds of a similar nature.

The second division comprises the majority of known Birds all over the World.

In treating of the Birds of North America, we have, therefore, to do only with the

\section{CARINATE BIRDS}

For many years the great assemblage of the Birds of the World have been considered as belonging to three separate spheres of activity :

1. Those which live in the air,

2. Those which live upon the ground,

3. Those which live in the water.

It has always been so difficult to form any real and stable divisions in this portion of the Animal Kingdom (as in any other portion, in fact) - as one group often so insensibly drifts 
into another - that, really, we have come to unite these two into one, and shall speak hereafter only of the LAND BIRDS and the WATER BIRDS.

Nearly every writer upon scientific subjects uses different names for the different divisions into which he separates his subjects. These names with one are often applied in exactly the reverse order with another writer upon the same subject. We shall endeavor to be consistent in our use of all terms.

We will illustrate, then, the manner in which the various terms are used as follows :

\section{KINGDOM Animal,}

SUB-KINGDOM Vertebrate.

GROUP Aves or Birds, SUB-GROUP Carinate Birds,

CLASS (Carinate Birds have two classes, the Land Birds and the Water Birds). SUB-CLASS (the Land Birds only are thus divided, into Aerial and Terrestrial Birds).

The three Sub-Classes are usually designated as fullows:

\section{AERIAL BIRDS OR INSESSORES \\ II TERRESTRIAL BIRDS OR CURSORES III AQUATIC BIRDS OR NATATORES}

Again, the Birds of North Averica belong to ELEVEN DIFFERENT ORDERS.

Each Srb-Cicass has its own distinct Orders, let us tabulate them, then, together,

\section{SUB-CLASS I AERIAL BIRDS}

ORDER 1 PASSARES or Perchers.

2 PICARI $¥$ or Picarian Birds.

3 PSITTACI or Parrots.

4 RAPTORES or Birds of Prey.

5 COLUMBA or Dove-like Birds. 


\section{SUB-CLASS II TERRESTRIAL BIRDS

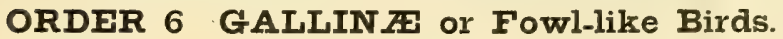 \\ " 7 GRALLATORES or Wading Birds. SUB-CLASS III AQUATIC or WATER BIRDS ORDER 8 LAMELLIROSTRES or Duck-billed Birds. " 9 STEGANOPODES or Totipalmate Birds. \\ " 10 LONGIPENNES, Long-winged or Gull-like Birds. \\ " 11 PYGOPODES or Diving Birds.}

Let us examine these orders more closely and see in what respect they differ one from the other.

The leading features of the different Orders of Birds, and their necessary divisions into Sub-orders, may be shown as follows, - though the Sub-orders, as a rule, are of comparatively little importance to the student as they show merely a. character, and not always a stable one, of the Order.

\section{ORDER I PASSARES}

Latin Passer, a sparrow or sparrow-like bird.

They have the hind claw equal to or greater than the claw of the middle toe. Toes one behind and three in front. Bill without cere. Toes never reversible. Tarsus envelope generally entire behind. Greater wing coverts not half as long as the primaries. Tail almost invariably of twelve perfect feathers. Having but one carotid artery. The Sub-orders are two.

\section{Sub-order 1 OSCINES or Singing Birds}

\section{Latin oscen, a singing bird.}

Though all the birds of this sub-order do not sing, yet the vocal apparatus is highly developed with, usually, five distinct pairs of singing or vocal muscles. Generally the tarsus covering is divided into two plates which meet behind in a conspicuous ridge.

\section{Sub-order 2 CLAMATORES or Screaming Birds}

Latin clamator, a brawler.

These birds have no well-developed singing muscles, conse- 
quently their note is a discordant scream. The tarsus is not ridged behind; but composed merely of scutellate plates throughout.

\section{ORDER II PICARIAE}

Latin picus, a woodpecker.

They have the hind toe rarely equal to, generally less than, the middle claw. Toes in pairs. All toes excepting the middle one capable of being reversed. Tarsus covering never entire behind. Bill without cere. Greater wing-coverts as long as or longer than one-half the primaries. Tail generally of ten perfect feathers. The birds of this order (together with the Parrots) have been variously named by former writers as, Strisores, Scarsores, and Zygodactrui ; all referring to the same or very nearly the same groups which we now combine under the name of PICARIne (Woodpecker-like) Birds, from the similarity of the characters and disposition of the feet in all of them, being very short and week.

The Sub-orders are three: [The birds of this order fall naturally into three groups, the birds of each group very closely resembling each other ; ret, without doubt, this is the most difficult order to define in all ornithology, and when defined the most unsatisfactory].

\section{Sub-order 1 CYPSELI or Swift-like Birds}

Greek kupselos, a species of swallow.

Wings long and pointed; feet weak and small: toes never in pairs. [Some birds have the anterior outer toe reversible, so that they sem an if two in front and two behind (owls wil! sometimes present this peculiarity) they are then called Zygodactylous]; bill varions]y shaped, but weak; syrinx with one pair of muscles.

\section{Sub-order 2 CUCULI or Cuckoo-like Birds}

Latin cuculus, a cuckoo.

Feet generally small; toes usually zygodactyle; bill vary- 
ing, but mostly hard and strong, not weak; syrinx with more than one pair of muscles. This sub-order is usually defined as including all the birds of the order not included in the two other sub-orders.

\section{Sub-order 3 PICI or Woodpecker-like Birds}

Same as Order 2.

This sub-order generally refers almost exclusively to the Woodpeckers. Wings of ordinary character, not unusually long and pointed; hind toe not unusually short ; toes in pairs, zygodactyle; bill stout and straight, not weak; tongue long and slender.

This whole order is usually best treated by defining the separate families in the successive order of their likeness to eachother; this is really no great labor as there are not many of them. It is about the only order among the birds that cannot be readily divided. The young student will do well to study the order thoroughly by itself, and become perfectly familiar with the forms that oceur in it, - it will then divide itself in his mind naturally and give him eomparatively little trouble in referring its members to their proper places.

\section{ORDER III PSITTACI}

Latin psittacus, Grcek psittake, a parrot; Greek sizo, to hiss.

Bill with a cere, and with upper mandible curving over the under; feet zygodactyle. No one would ever mistake the general form and appearance of a parrot, though the species are very few here in North America. It has no special suborders here.

\section{ORDER IV RAPTORES}

Latin raptor, a robber.

This order is so distinctive in its characters as to be readily told from any of the other orders, even without the aid of special characteristics. Like the Parrots, it has the bill with a cere and with the upper mandible curving over the under, but 
the feet are never truly two in front and two behind [(zygodactyle), though one of the front feet in the Owls moves backward sufficiently for these birds to sit on a perch and clasp their prey as they fly with two feet in front and two behind, thus appearing only to be zygodactyle]. The student of osTEOLOGY will find several distinctive characters exclusively pertaining to this order, and even in the different sub-orders.

The Birds of Prey are usually separated into

A THE NOCTURNAL BIRDS OF PREY containing the Sub-order

1 STRIGIDES OY OWLS

B THE DIURNAL BIRDS OF PREY

containing the Sub-orders

\section{ACCIPITRES OY FALCONS HAWLS EAGLES 3 CATHARTIDES OY VULTURES}

The Nocturwal Birds of Prey are at once distinguished from the Diunal Birds of Prey, by the peculiar shape of the feathers about and around the eye, by the bristly feathers about the bill, the reversible outer front toe, and the soft, fluffy plumage of the Owls (Nocturnal) compared with the clean-cut bill and cere, the tongh-skinned feet, and the rough, hard plumage of the Hawks, etc. (Diurnal) Birds of Prey. The Sub-orders are three.

\section{Sub-order 1 STRIGIDES or Owls}

Latin strix, a screech owl; Greek strigx, a screech.

The Owls are not easily mistaken for birds of either of the other sub-orders of this order. The radiating disc of feathers surrounding the eyes; eyes large, soft, and watery; the bristly feathers almost hiding the bill; the tomia of upper mandible without tooth or notch; the nostrils partly in the horn of the bill and partly in the cere; with reversible outer front tue; legs feathered nearly or quite to the toes; together 
with the soft fluff of the plumage; everywhere characterize these birds. An Owl is an Owl, and could seldom be mistaken for any other bird.

\section{Sub-order 2 ACCIPITRES or Hawks etc}

Latin accipiter, a general name for birds of prey.

The Hawks and their allies are rather harder to characterize than the Owls, yet their peculiarities are none the less persistent: Only an occasional disc, and that au imperfect one; eye, though not large, fierce and fearless; stiff feathers do not hide the base of the bill; cere entirely surrounding the nostril openings; tomia of upper mandible seldom if ever without notch or lobe of some kind, be it never so faint; toes seldom if ever retractile; legs seldom feathered, and toes never; whole plumage more or less tough and roughened.

\section{Sub-order 3 CATHARTIDES or Vultures}

Greek kathartes, one who purifies.

Were this sub-order merged in that of the Hawks, ete., the distinctions between (1) and (2) would be mainly by the presence or absence of positive or negative characters; as it is, they are separated from (1) easily enough, from (2) as follows: feet weak, long, more or less blunt; hind toe as also its claw short, and elevated above the others somewhat; toes not retractile, front ones webbed at base; nostrils open from one side of bill to the other; bill long and little curved, not toothed at tip; head more or less naked.

\section{ORDER V COLUMBAE}

\section{Latin columba, a dove or pigeon.}

This is another of the small yet very decided orders, seemingly marked out almost exclusively for birds of the dove and the pigeon families. It would be useless to define its suborders as but a single one exists in North America. The order is the same as the Pullastre of old authors [with the addition, perhaps, of the TExAN GUAN]. In characters it has bill without cere, naked at base but with a distended 
membrane enclosing the openings of the nostrils. One would hardly mistake the peculiarities of a common domestic pigeon, which represents the order well : the striking features of the bill, the feet, and the soft, compact plumage, are noticeable throughout the birds of this order. These birds are very closely related to the old order of RAsores, which included them with the next order (the Galims.); but we seldom use the name now.

It will be observed, that with the CoLumbe we close the Sub-class of Aerial Birds. [The Trsessones, as they are still called, which, with the Cursores, the Grallatores, and the N.tATOREs, form all that remains to us of the misleading names of the old-time classification of early writers].

\section{ORDER VI GALLINAE}

Latin gallus (m), gallina (f), a domestic fowl.

The Galline is still another small yet well-defined order. It is also, so to speak, an historic order, being really the old order of RAsones or Seratchers. Its principal members are easily separated: for, - though some of the species show characters which agree well with some of the Plovers thus approaching the Wading birds - on the one hand; and an the other it contains, at present, the Trxax GuAx, which is sometimes placed with the order Corcur.x, - no one would fail to recognize instantly the forl-like appearance of its members, the Grouse and Quails. I should define the order as follows: Bill short and stout and shorter than the head, base not covered with a soft membrane (as in CoLumbe); legs rather long, toes short, usually elevated somewhat above the rest, and with connerting membrane at their hase; general appearance fowl-like.

Some writers divide the order into two sub-orders, - but this does not seem necessary, as there are so few birds in it that it would hardly be required, especially as one of them 
contains but a single species which might, almost equally well, belong to the previous order, I refer to the GUAN.

The Guan differs from all the other related birds by having what are called pigeon-like toes, the hind toe being situated scarcely if any above a level with the others, and longer than in the other families.

\section{ORDER VII GRALLATORES}

Latin grallator, "one who goes or runs on stilts."

Science is not prepared to wholly do away with this old yet perhaps well-chosen name. These are the Waders. The old name of Shore Birds, often applied to the whole order, is misleading, as several of the species seldom visit shoreward, but remain in the interior. The special characteristics of the order are: Legs long (with but few exceptions), naked far above the knee joint, thigh joint generally not enclosed within the body; toes with no, or only a very small, basal membrane; nostrils exposed and not covered by feathers or bristles; bill usually very long (or rather long, and weak, and thin); tail short.

Some authorities divide this order into two sub-orders, the second of these being again divided into what they term "Tribes"; but this seems unnecessary, because, of there socalled Tribes, one, the third, is a distinct Sub-order, and the other two make a false separation of another Sub-order. Our best writers make three full Sub-orders, as follows:

[Division A. Young able to run about from the time they are hatched from the egg, Precoces].

\section{Sub-order 1 LIMICOL㘴}

Latin limicola, "a dweller in the mud."

Shore Birds. - Hind toe short and elevated, or absent; bill short or slender, membranous, and with nostrils usually in a slit in the membrane; plump bodied. 
[Division B. Young fed from the nest, Altrices].

\section{Sub-order 2 HERODIONES}

Greek erodas. a heron.

Heron-like Birds. - Hind toe long and slender, not obviously elevated; bill long and stont, and hard; body compressed; neck lengthened.

[Divisios C. Young able to run about from the time they are hatched from the egg, Precoces].

\section{Sub-order 3 ALECTORIDES}

Probably Greek alektos, incessant, referring to their incessant clatter.

Crane-like Birds. - Toes long with hind toe lengthened and not obviously elevated; embraces birds similar to those of each of the foregoing sub-orders yet obviously different; tail short and of few feathers; bodies compressed; neck and legs rarely unusually lengthened.

Comparing what I have called Division A with Division B, it will be seen wherein our present three sub-orders become two of many writers. Thus,

Division B becomes Sub-order 1 Herodiones,

Division A becomes Sub-order 2 Grallæ.

Many writers use these two sub-orders to-day. When this is done Sub-order 2 Grallæ is further separated into,

Tribe 1 Limicolæ or Shore Birds,

Tribe 2 Paludicolæ (Alectoridæ).

But this still leaves us the Limicolie to separate into still smaller divisions, both on account of their number and their peculiarities, until we become confused unnecessarily.

[The old Sub-class Cursores (What we now call Terrestrial Birds) or Runners, contained also our present Order 6 Galime. The Brevipenses are the extra-limital. Ostriches, ete. and were included among the GraLLATOREs. Our Order 6 Galdix $\mathrm{E}$ is also the old Sub-class Rasores (in- 
cluded also among our Terrestrial Birds). 'The present (Order 5 Columbe moreover belongs to them. It was thus, formerly, the great question of the day as to how to reconcile all these inconsistencies. By rejecting entirely the old systems and substituting the new this now becomes possible].

The young student will notice how difficult it is to characterize, with any degree of exactness, the various divisions in Ornithology ; the difficulty will increase rather than diminish as he progresses. As he becomes familiar with the individuals from which the characters of these divisions are drawn, however, the matter will appear to him in a new light, and his difficulties will decrease with experience.

We now come to the third Sub-class, the Aquatic or Water Birds, usually called the Natatores or Swimmers. Established usage still separates these into what we may call,

\section{Division A ANSERES and Division B GAVI㘴}

The latter (Division B) are called Altrices, or Birds that rear their young in nests and feed them ; the former (Division A) are called Precoces, or birds whose young run about and procure their own food almost from the moment they are hatched from the egg. To make these characteristics a basis upon which to divide the remaining birds would be useless, as our present system is so clear and well-defined on these points.

\section{ORDER VIII LAMELLIROSTRES}

Latin lamina, "a thin plate or layer"; and rostrum, the beak.

Bill with that peculiar arrangement of layers or plates along its edge called lamella, resembling somewhat " the teeth of a saw," as the Latin gives it - It is recognized instantly by the student. The greater portion of the bill is membranaceons Feet palmate; hind toe elevated (sometimes absent) and free. The great assemblage of Swans, Geese, and Ducks, form the principal and almost entire portion of this order. 
Science still persists in framing a separate sub-order for that awkward monstrosity of nature the Flamingo, and so we divide the order into two sub-orders. [It should be remarked that most authors place the Flamingo, with the Spoonbills and Ibises, among the Herons]. It seems rather unfortunate that we should be obliged to mar an otherwise symmetrical order for this bird, but there seems to be no help for it.

\section{Sub-order 1 PHCENICOPTERIDES or Flamingoes}

Greek phoinikopteres, red winged; Latin the same.

With long legs; stout, curved bill ; long neck ; short tail ; color red. Also called Pseudo- (false) Lamellirostres.

\section{Sub-order 2 ANSERES or True Lamellirostres}

Latin anser, a swan.

The Swans, Geese, and Ducks belong here, and as the order itself fully characterizes these it will not be necessary to repeat them here.

\section{ORDER IX STEGANOPODES}

Greek steganos, covered, closed up; pous, a foot,

Bill not laminate or membraneous; hind toe large, on a level with the other toes, and webbed with the inner toe; feet totipalmate. Nostrils small. Throat with pouch ealled the gula pouck. The birds of this order are birds having little real likeness either to any of the orders which immediately precede or those which follow it, or to each other. That they should conform sufficiently to characterize an order by themselves, is indeed a surprise; yet such is the fact.

\section{ORDER $X$ LONGIPENNES}

Latin longus, long; and penna, a wing.

This order is not easy to characterize, though its members all bear a certain resemblance which, of itself, is one of its most constant features. The bill is never extensively either lamellate or membraneous, though it varies strangely and very strongly in many of its indiriduals, - it can hardly be relied 


\section{OF ORNITHOLOGY}

on as a permanent distiuguishing character ; the legs occups. a position midway between those of the precerling and of thr. following orders, and more nearly balance the body as in the Insessores or Perching Birds; hind toe, when present, free ; wings of special importance, and long - usually extending to beyond the base of the tail - flat, and narrow, hence the power of flight is strong and flight swift, well-sustained, and often long-continued, and the usually light body is well in keeping with these characteristics; nostrils open; no pouch on throat; web of feet variable in the different families. The two sub-orders are :

\section{Sub-order 1 LARIDES or Gulls, Terns, etc.}

\section{Latin larus, Greek laros, "a ravenons sea-bird, the mew."}

The birds of this sub-order would be better characterized by their families than collectively. Tostrils not tubular but linear. The Larides comprise four families, quite distinct, and with the birds of each conforming well with each other-to the more advanced student, a glance will usually determine, withont question, to which of the four a specimen belongs.

\section{Sub-order 2 PROCELLARIDES or Petrels, etc.}

Latin procella, a storm bird.

The birds here comprise two families, of which the familiar Albatros forms one of them and the difficulty is much diminished. Nostrils tubular.

\section{ORDER XI PYGOPODES}

Greek puge, buttock or rump ["tail"]; Greek pous, a foot.

Our last order comprise what are usually characterised as "the Diving Birds." They walk with difficulty as their legs, as their name indicates, are situated at the extreme end of the buttock or rump, so that walking with any degree of comfort is impossible - their gate being an extremely awkward waddle, and they do as little walking as possible. The wings are more or less rudimentary, - long, narrow, and for the most part not well-dereloped. Hind toe, when present, free; tail 
rudimentary. About the only thing that they do well is to swim both in and under the water. The three families which compose the order conform sufficiently to preclude the forming of sub-orders.

The above brief characterization of the Classes and Order's of our Birds, though made primarily for the use of students of North American Ornithology, will apply almost equally to the birds of the whole world, - which number about 12,000 species. The numbee of North American species are about 900 , or less than one-thirteenth of the above number; yet, by our most recent authorities, they include every order known but two. The Brevipexses or Ostriches, etc, and the SpHexicE or Penguines, alone accepted; but they form a very small per cent. of the whole number. In order, then, that we may have the field fully before us, a brief mention of the usual classification of the Birds of the World will now he introduced. It will do well for the use of the student as he adrances in study; and, I think, be equally understood by the amateur who has reached thus far in his work amongst these most charming subjects of the present sketch.

What we have styled in the beginning of our analysis the Old School Ornithologists, divided the Birds of the World into sfrex Groups - called sometimes Classes and sometimes Orders - as follows:

\section{RAPTORES or ROBBERS}

II SCANSORES or CLIMBERS

III INSESSORES or PERCHERS

IV RASORES or SCRATCHERS

V CURSORES or RUNNERS

VI GRALLATORES or WADERS

IIV NATATORES or SWIMMERS 
The characteristics of these Orders can be readily defined, should one care to distinguish them, by what has already been said in the foregoing pages. These groups held until within a comparatively few years. The FossiL Birds have not been included, so far, in any of our analyses.

Our various institutions of learning, throughout the countay, before what we call the New System was very generally adopted, arranged the Classes of Birds as follows:

\section{SUB-CLASS I INSESSORES}

\section{Order 1 PASSARES Oscine and Clamatorial Birds}

2 STRISORES Humminq Birds and Kingfishers

3 ZYGODACTYLI Parrots and Woodpeckers

4 ACCIPITRES Birds of Prey

5 PULLASTR Pigeons and Doves

\section{SUB-CLASS II CURSORES}

“ 6 GALIIN王 Grouse and Turkies

7 BREVIPENNES Ostriches

8 GRALL正 Plovers and Herons

\section{SUB-ORDER III NATATORES}

“ 9 LAMELLIROSTRES Swans Geese Ducks

" 10 STEGANOPODES Pelicans Cormorants

“ 11 LONGIPENNES Gulls Terns Petrels

“. 12 PYGOPODES Diving Cirds

By careful comparison of this "Intermediate Series," as we may call it, with both the old and the new classification, it will be seen to be a decided step in advance of the old, while foreshadowing the new. But few writers continue to use it at the present time.

We now come to what we will call the New System, in distinction from the others which we have thus far enumerated. This system is well recognized as embodying the latest results of the best workers in this department of science. 


$\begin{array}{crl}\text { ORDER } & 1 & \text { PASSARES } \\ " & 2 & \text { PICARIAE } \\ " & 3 & \text { PSITTACI } \\ " & 4 & \text { RAPTORES } \\ " & 5 & \text { COLUIMAE } \\ " & 6 & \text { GALLINAE } \\ " & 7 & \text { BREVIPENNES } \\ " & 8 & \text { LIMICOLAE } \\ " & 9 & \text { HERODIONES } \\ " & 10 & \text { ALECTORIDES } \\ " & 11 & \text { LAMELIIROSTRES } \\ " & 12 & \text { STEGANOPODES } \\ " & 13 & \text { LONGIPENNES } \\ " & 14 & \text { PYGOPODES } \\ " & 15 & \text { SPHENICI }\end{array}$

Omitting orders 7 and 15 , it will be seen that our foregoing classification, answering perfectly well as it stands for grouping the known birds of the world, will serve us for classifying our present known North American species. Orders 7 and 15 are so individual in their character, and so easily to be recognized, that they need no special additional mention. Order $\bar{T}$ stands for birds of the Ostrich type and order 15 for the Pencieiss. Thus is the field of Universal Ornithology merely suggested rather than fully treated of. To further separate and characterize the families of the Birds of the World is no part of the duty which we have laid upon ourselves, in the arrangement of the present work. In properly setting forth the families of the Torth American species, we shall find that we will have our hands more than full: nevertheless, we shall attempt to do it, and hope that our efforts will prove satisfactory to ourselves and to those who may choose to avail themselves of the results of our labors in this most fascinating and delightful field of research. 
To properly characterize the Families, Sub-Families, and Genera, and to name the Species, of North American Birds would require more space than the limits of these few pages of preliminary study will permit. Nor is it always easy to give even the mere necessary determining marks of family, sub-family, and genera. We could not, with propriety, say that any one division DEVELOPs into or from another; yet, one group drifts so insensibly into another that, as yet, the greater part of our system is, of necessity, merely artificial. Different writers often place the same species in very different genera or even families; hardly any two writers will agree as to the members of each group. Of one thing only can we be certain : namely, the individual. This remains constant wherever it is found. The wise student, therefore, ignores, in a very great measure, all systems of classification, and studies the individual. This is especially evident when, as often happens, a single new genera, sub-family, and even family are formed for a single species. To the individual, then, we must all go, sooner or later; but it is not our object here to study so much the different members of our various groups as to ascertain the present state of our knowledge of the higher divisions, that, by their careful arrangement, we may be brought to a wiser grouping, if possible, of the individual. Many of our divisions are known more by the members which they contain than by any of the usual arbitrary " characteristics" ; in fact, some of our so-called families can not be characterized at all, so varied are the individuals included within them. Of these the Thrushes are a good example.

\section{LAND BIRDS.}

\section{FAMILY I TURDIDAE THE THRUSHES}

Latin turdus, "a thrush, a field-fare."

The main characters of this family are: Tarsus booted] primaries ten, the first spurious or quite short ; wings longish and pointed and generally shorter than the tail; bill mostly 
long and slender, nearly straight or very little curved and notched more or less distinctly at the tip, with roundish or oval nostrils, and not concealed by the stiffish bristles of the base of the upper mandible; tarsus rather long and slender and generally longer than the middle toe and claw, the scutella fused into a single plate; tail feathers twelve, rarely any longer than the wings (only so in Mimus) and merely rounded.

It will be perceived, at a glance, that the characteristics of this family are modified frequently by some such word as usually, generally, etc., and not boldly set forth, as are most of the following families, in precise language. Yet it is one of the oldest families that we have, and the hue and cry would be something terrific should we cause it to disappear; still we venture to predict its removal in the near future.

\section{Sub-family a TURDIN $\Psi$ True Thrushes}

Bill straight and shorter than the head; nostrils oval, and situated just beyond the rictal bristles ; first quill of the wing truly spurious; tail shorter than the wings; tarsus booted, and in length equal to or barely longer than the middle toe and claw ; wings typical of the family.

Genus, Turdus, The True Thrushes (13 species).

Sub-Genera, Merula, Hesperocichla, Turdus.

[These SEB-GENERIC names are applied to different species by different authors, who wish to still further separate the members of the genus, and are often given the rank of true genera; the name Hylocichla is also often thus used. We prefer the single, well-known name of Turdus for all the species under the present sub-family.

Note. - Of the many changes in Oruithological nomenclature which have been made, within the past few years, that of raising the above sub-genera to the rank of genera will, doubtless, in time, be fully accomplished though we look forward to it with regret. The Robin and the Thrushes deserve to have a decided and definite distinction: Yet so strongly does 
the former still appeal to us as a 7hrush - a typical Thrush that we can hardly bear to separate it from the genus Turdus, especially as this involves, to a very great extent, new genera and new relations for the remaining individuals of the subfamily,

\section{Sub-family $b$ MIMIN $\#$ Mocking Thrushes}

Bill much as in Turdince, but usually slender, long, and curved - often in a remarkable degree; first quill of the wing nearly one-half as long as the second; tail equal to or longer than the wings; wings short and somewhat saucer-shaped; tarsus with (mostly) distinct seutellæ.

Genera, Oréoscoptes, The Mountain Mocker.

Mimus, The True Mockers (2 species).

Harporhynchus, The Thrashers (10 species).

Sub-Genera, None, unless we admit Galeoscoptes in place of Mimus for the Catbird, - but, in so doing, we must raise it to the rank of a genus, which there seems to us no especial reason for doing. It is pressing a point, somewhat, even to insist upon making Oreoscoptes distinct from Mimus, - yet this is pretty generally conceded, at present, though applied to but a single species.

\section{Sub-family $c$ CINCLIN $\Psi$ Dippers}

Bill shorter than the head; nostrils in slits (linear), open; no rictal bristles; tail short and square; wings longer than tail ; first quill about one-half the length of the second ; with booted tarsus. (Aquatic.)

Genus, Cinclus, The Water Ouzel.

Sub-Genus, None. The sub-family itself being formed for a single species apparently quite eonstant.

\section{Sub-family $d$ SAXICOLIN \&1 Chats}

Bill shorter than the head, small and weak; nostrils oval and rictus with bristles; wings long and pointed with first quill very short (spurious); tail short, emarginate, or squared; tarsus booted and generally but not always longer than the middle toe and claw. 
Genera, Saxicola, The Stonechats.

Cyanecula, The Blue-throat.

Sialia, The Bluebirds (3 species).

Sub-Genera, There seems no good reason for any separation here into sub-genera. As the first two genera are each for a single species, Sialia alone remains, and this seem incapable of any further division.

\section{Sub-family $e$ REGULIN \& Kinglets}

Bill very small and delicate, short, and straight; nostrils more or less exposed; wings straight, with a spurious first quill; tail emarginate or almost even ; tarsus booted, and longer than the middle toe and claw. Species very small.

Genera, Phylloscopus, The Kennicott's Warbler.

Regulus, The Kinglets (5 species).

Sib-Genera, None, as of the two genera the former is for a single species and the latter is the same as its neighbor Sialia, incapable of further division.

\section{Sub-family $f$ POLIOPTILIN 7 Gnat-catchers}

Bill much as in the last sub-family (Regulino) but longer and very slender, wide and flat at base, with notch and hook at tip; rictus with bristles; nostrils not covered; first quill half as long as the second; tarsus scutellate.

Gexus, Polioptila, The Gnatcatchers (3 species).

To transfer Phuinopepla and Myiadestes (each for a single species) to the Thrush family, as is done by some authors, (after Sialia and before Polioptila, from the family of the Waxwings MAY, presently, become established, - it is not necessary to discuss the change here.

\section{FAMILY II CHAMAEIDAE THE WREN TIT}

Latin cama and Greek chamai, to dwell "on the ground."

A small family which it is very hard to define. While radically different from any of the Thrushes, it has been placed with the Wiens, though seemingly with more of a likeness to the Titmice: Wings short and rounded, very noticeably so, and about one-third shorter than the tail, which is also round- 
ed ; general plumage "lax," and very soft; tarsus without distinct scutellæ and longer than the toes; long rictal bristles about the base of the short and compressed bill [bill less than the length of the head]. An instant's comparison of the bird with those which it resembles will show how necessary it is to frame a separate family upon its stable peculiarities.

Genus, Chamoea, The Ground Tit and ally.

[The position of this family, numerically, is liable to be changed, with perfect propriety, at any time].

\section{FAMILY III PARIDAE THE TITMICE CHICKADEES}

Latin parus, a titmouse.

As we progress in the enunciation of the characteristies of the family groups, our difficulties increase rather than diminish; Strange as it may appear, the Titmice are allies to the Jays; most of our writers regarding their differences merely as a difference of size. There is no necessity of attempting to divide the family into sub-families, as our North American species would fall naturally under a single sub-family: Bill short and stout, straight and somewhat compressed, tip straight and unnotched; nostrils concealed by stiff feathers (not bristles); tarsus scutellate and longer than the middle toe; toes stout for size of bird; wings (primaries 10) with spurious 1st quill - one-half or less the 2nd - wing about length of tail and both rounded; tail (12 feathers) not acuminate. Size small, five to seven inches only.

Genera, Lophophanes, The Crested Tits (4 species).

Parus, The Chickadees (11 species).

Psaltriparus, The Tits (3 species).

Auriparus, The Yellow-headed Titmouse.

Sub-GENERA. None: There seems to have been little desire on the part of writers to separate these well-grounded and will-established genera. Two or three species only rest under an apparent temporary cloud, - but this seems a matter more of local variation than distinction of type. The species are not abundant, and in form and position pretty reliable. 


\section{FAMILY IV SITTIDAE THE NUTHATCHES}

Latin sedeo, I sit: referring to the manner in which the bird sits upon the tree or limb.

The present family, untouched by the hand of time, still throws its beacon, its defiance, with undiminished rays, upon the pathway of Ornithological literature. With comfort can we look back from Audubon in 1838-39, to Nuttall in 1832, to Wilson in 1808 , to Latham in 1790 , to Gmelin in 1788 , to Linnæus in 1766 and 1735 ; and see Sitta - in the same letters and the same relations - as transcribed by the scientist of to-day. Of but few families can this be said, and we are justified in stopping, for an instant only, to contemplate some of the changes wrought by time in our ornithological literature and characterization. The general features of the family are: Bill about equal to head, straight, sharpely tapering to point, compressed, and slender; nostrils roundish and concealed by bristles, which are in tufts; wings nearly as long as the tail, and with 1st quill spurious or less than one-half the $2 \mathrm{~d}$; tail short, and nearly even [while the wings are, comparatively, long, narrow, and pointed, the tail is short and broadened]; tarsus about equal to the middle toe, stout, and with scutellæ. General plumage soft and almost greasy in feeling. The species are easily distinguishable at sight.

Genus, Sitta, The Nuthatches (5 species).

We can find no record of either sub-genus or synonym; if any are known they are of no value at present.

\section{FAMILY V CERTHIIDAE THE CREEPERS}

Said to be from Latin "Certhius, a creeper," - but I can find no such word in my lexicons.

The characteristics of this small family are striking and peculiar. The small size of the bird; the long, slender, and sickle-shaped bill; the sharp claws, and long claws of the hind toes; the stiff, rough, and sharp-pointed [acuminate] tai! feathers; all determine it at a glance. The single genus is nearly, if not quite, as old as Sitta and fully as familiar. It seems absurd to construct a separate sub-family for the only 
two known American species, nor shall we attempt it, as it would simply be a repetition of the fumily characteristics already given above.

Genus, Certhia, The Brown Creeper and ally.

I can find no record of either sub-genus or synonym (of genus).

\section{FAMILY VI TROGLODYTIDAE THE WRENS}

Latin Troglodyto, Greek Troglodutai, a cave-dweller.

The typical Wren is a figure easily represented to one's mind, - to so characterize the family that it shall be instantly distinguishable, upon sight, is quite another thing - for it has features of many other families strongly engrafted into it, noticeably those of the Titmice and the Thrushes. Its special peculiarities are: The uniting of the basal joint of the inner and middle toes with part of the second joint of the outer toe. The bill varies in size and shape, but is slender and without terminal notch or basal bristles (rictal). Nostrils varied in shape and size, but not concealed save by a sort of roof or scale-like piece which lies above them. Wings short and like a miniature Catbird's, with short 1st quill. The tail and the tarsus vary with the species (forming genera) but, in general, preserving a more or less family resemblance, and with scutellæ (either before or behind - sometimes both).

The two sub-families are distinguished especially by the shapes of their tails, their size, and their other markings.

\section{Sub-family a CAMPYLORHYNCHIN 王 Fan-tails}

Size large, being $7 \frac{1}{2}$ to 8 inches in length or over; tail very broad at tip, and fan-shaped.

Genera, Campylorhynchus, The Cactus Wrens and ally.

- Salpinctes, The Rock Wrens and ally.

Catherpes, The White-throated Wrens and two allies.

Sub-Genera, None.

\section{Sub-family $b$ TROGLODYTIN $\nexists$ True Wrens}

Appearance more like that of a typical Thrush; tail not fin- 
shaped, but more nearly equal-edged throughout the entire length of its feathers, and delicate ; size small ; plumage more or less completely barred.

Genera, Thryothorus, The Great Carolina Wren and allies (6 species). Troglodytes, The House Wrens (3 species). Anorthura, The Winter Wrens, (3 species). Telmatodytes and Cistothorus, The Marsh Wrens (3 species).

Sub-Genera, None, unless Thryomanes be considered a sub-genus of Thryothorus.

In this family, as in several others, species are often transferred by different writers, from one genus to another, without the use of specific sub-genera.

A careful comparison of the toes of the two sub-families will show a marked difference which were hard to explain of either one alone.

\section{FAMILY VII ALAUDIDAE THE LARKS}

Latin "alauda, the lark, 'a Celtic word, literally great songstress.",

This is a small family made, apparently, originally for a single species. One or two varieties and one extra-limital species have crept into it, however. North America is noted for a great many of these peculiar one-specied families. The larks are noted for: The peculiarly shaped head horns or crests, and the immensely lengthened hind toe nail - these alone would distinguish the family. They have, also: the tarsus scutellate; wings long and pointed, 1st primary spurious or wanting; bill short, stout, pointed; nostrils more or less concealed by tufts of feathers. The tail hardly enters into the composition of the family characteristics. Until recently the family admitted of but a single sub-family ; the recently imported European Skylark, however, would naturally add a second sub-family. It does not seem necessary to allow this in the present instance: The main difference being in the presence or absence of a spurions 1st wing quill, this is wanting in the European Lark. The different places in the families of birds which are given to the members of this fam- 
ily, show clearly how difficult even yet it is to decide just where, as a family, it belongs. We prefer to place it here, so that we may show the difference between it and its nearest allies the Titlarks.

The two sub-families into which this family are divided are,

a CALANDRITIN 五 Shore Larks

\section{$b$ ALAUDIN $¥$ Skylarks}

These are misleading, as the old and still much used name for our American Shore Lark was Alauda, and here we apply it exclusively to the European Skylark as Alauda arvensis; while now, though placing our American Shorelark in the subfamily Calandritince we do not use the name with a generic signification and say Calandrita. It is, therefore, better to do away with sub-families entirely, and give the family two

Génera, Eremophila, The True Larks (3 species).

Alauda, The Skylarks.

Though these names are often used as synonyms they are quite distinct.

\section{FAMILY VIII MOTACILLIDAE THE WAG- TAILS TITLARKS PIPITS}

Latin Motacilla, "The White Water Wagtail."

The similarity, in many respects, of this family with the preceding (VII) places it, naturally, next in order. Those unacquainted with the species, except in name perhaps, readily confound them, yet they are radically distinct. They have: Bill short, slender, straight, and with noticeable notch at tip ; nostrils open (not concealed by feathers); wing without a spurious quill (primaries 9) and of about the same length as in the tail ; tarsus with scutella, and hind toe nail long and not much curved. A comparison of the specimens of these two families will show the distinct peculiarities of the tarsus and the toes and their clefts in each. The sub-families are each well defined. 


\section{Sub-family a MOTACILLINAE True Meadow Wagtails}

Tail not shorter than the wing, of which the 3rd quill is the longest.

Genera, Motacilla, The White Wagtail and ally.

Budytes, The Yellow Wagtail.

\section{Sub-family $b$ ANTHINAE Titlarks and Pipits}

Tail shorter than the wings, of which the 4 th and 5 th quills are the longest.

Genera, Anthus, The Titlark and the Pipit.

Neocorys, The Missouri Titlark.

$($ Synonym $=$ Alauda. $)$

Sub-genera, None.

The members of this, as also of the preceding, family have been placed in so many different and peculiar situations, both in relation to themselves and to that of the other Insessores, that it is best to leave a critical examination of them to the more advanced student. A few facts may be noticed, however: In the present case, the two sub-families are perfectly justifiable, for, examining the different works on Ornithology to-day no one would consider the different genera as belonging to the same family. This will appear more evident when we remember that the recent name of the genera of the Titlark was Alauda, the same as was formerly used for our present Shore Lark. This would give us a synonym but not a subgenus. It will be noticed, also, that the American Titlark is not the same as the European Titlark; that the American Skylark (Shore Lark) is not the same as the European Skylark; and that the Skylark (whether American or European) is not identical with or even related to the Titlark (either American or European), notwithstanding the fact that so many of our writers will persist, wrongly, in placing them all in the same gemus Alatda. Budrtes is a distinct Motacilla. Both are different from the other members of either family, - though we are not prepared to arrange them any differently at prestnt 


\section{FAMILY IX SYLVICOLIDAE THE WARBLERS}

Latin Silva, woods; colo, I inhabit: sYLVAN.

The group of Warblers, or the American Wood-Warblers, as their name implies, are among the most interesting of all the groups of North American birds. They are so exclusively American, and the species are so numerous, as to render them familiar, attractive, and not easily to be forgotten objects of interest to every man, woman, and child throughout the length and breadth of our land. They occur, either as residents (during Summer mostly) or migrants, everywhere throughout North America; and are also found in Central and South America and the West India Islands. They form the greater bulk of what are known as the "migratory birds"; and their movements are so extraordinary, so peculiar, and yet so regular, as to be altogether inexplicable. The questions evolved in explaining their movements are so many and so involved that no one answer, or even set of answers, will account for all their actions. No rule can be set down for their occurring as either resident or migrant in any given area or locality, save that of actual observation; and even this often varies, from some wholly unknown cause, in different years. Examples are continually occurring of individual species which occur as "resident and breeds" in one limited locality which do not so occur again within a radius of hundreds of miles in any direction. Further, - in some states a species may be a common, even abundant, summer resident throughout the state, yet, in isolated places or towns perhaps, in the very midst of this abundance, the most strict search will often fail to detect a single individual of that species; or they may be found only as "very rare migrants." Were this true of a single state, there might be some reasonable answer to the question, Why is it? But it is equally true of every state or section of country in all North America.

The question of the position of the Sylvicolidre among our other North American birds, is one very easily disposed of as being one merely of natural affinity. That of "what birds 
constitute the family," though now settled with much certainty, was a much more difficult one to decide. Should we enter into the question, as some authorities seem disposed to do, of what features of other groups in other families do the individuals or genera of this family possess, we shall have our hands at once so full that a separate volume would be needed to fully explain the relationship. We might give it the name of Sylvanologr; and to discuss this fully would involve a discussion of nearly two-thirds of all the species of Insessorial Ornithology. The advanced student will soon discover "likenesses," as well as see in what lines to push his inquiries. For the present, the young student had best seek to know in what respect the included forms are like themselves, then the resemblance of individual forms to other and outside species will open to him naturally. We will proceed, then, to give the very difficult formula which characterizes the group.

In General: Let the young student procure a specimen of a species of Sylvicolidæ, which he has shot himself or obtained from some museum or dealer or thorongh, systematic ornitholugist, and has been correctly named; then, taking this as a model, proceed to make his own diagnosis (as it is called) of its characteristics. To do this almost any of the True Warblers will answer. When he has carefully written out all these evident characteristics, let him apply them to any of the other forms in the family. He will then find that, with very little change, they will apply equally well to erery species of the sylvicolidie. And that they will not apply, except with rery great change, to any other family of North American birds. Then the characters of this family are, in the main, negutive characters. In the above manner, only, have I been able to separate the group with any degree of satisfaction, either to myself or to others.

In Particular: Size small; bill short, conical, and abruptIy acute, even or rery faintly notched at end ; tarsus, feet, and toes symmetrically regular and not, any of them, abnormally developed; tarsus scutellate; wing and tail regular and sym- 
metrical in length, shape, and outline, and are not abnormal in shape or looks; the tail is composed of 12 feathers, and the wing quills (primaries) of 9, and there is no spurious or half-sized 1st quill, that is equal in size to the other long quills. Only a very few of the members of this family vary from the form of the typical warbler. If left to his own course, a young beginner in the study of this group will, without doubt, pick out - from pure innate contrariness - these very forms and, thenceforward, can never make head nor tail of the group which will remain, forever after, an untangled mystery by reason of the disassociation of ideal.

The typical Warbler, then, determines easily this family from all others preceding or following it. The different individuals composing it fall, naturally, into three sub-families. And here just a word about the positions which are now, and were formerly, ocoupied by the members, or I should rather say by the species and even genera, of this family. I shall discuss as little as possible what other writers do and say, or where they place this species or that; our work is, if possible, to simplify and to harmonize ornithology - not to tear it to pieces and so complicate it that nobody can make head nor tail of it. What if several of the genera were formerly classified with other families? That is no reason why, in tne light of our present more perfect knowledge, we should not group together all those species which present the closest technical resemblances. This we have aimed at doing throughout the present work, rather than to speculate upon what older writers have incorrectly thought and said in the matter.

To assist the student in the better separation of this family we repeat here, for reference merely, the excellent divisions made use of by Professor Baird in the "Pacifie Railroad Report." So very little change will be required to conform the table to our present classification that the differences, if any, will become apparent upon very slight examination. Is his family Sylvicolide embraces the Larks and the Tanagers, we will begin with his Sub-family Sylvicolince. 
"SYLVICOLIN Æ. - Bill rather slender, conical, or depressed. Culmen straight or convex. Hind toe shorter than the middle; the claws all much curved; hind claw not conspicuously longer than the middle one. When the hind toe is lengthened, it is usually in the digit not the claw. Tertials generally not longer than the secondaries.

It may be conveniently divided into the following sections:

\section{A 'Rictus with short bristles or none.}

Mriotilteæ. - Bill notched. Hind toe longer than the lateral ones, its claw shorter than the digit. Wings pointed. Tail nearly even, spotted.

Geothlypeq - Bill notched Legs very stout. Hind toe longer than the lateral; its claw equal to the digit. Tail unspotted.

ICTERIEe, - Bill without notch, very stout, much compressed. Commissure and culmen both much curved.

VERMIVRE. - Bill entirely without a notch; conical, slender, weak, acutely pointed.

Srlvicoles. - Bill notched. Wings pointed. Hind toe equal to the lateral.

B Rictus with well-developed bristles.

Setophage.e. - Bill depressed, broad, notched at tip."

MnтотіLте contsins the genera Mniotilta, Parula, and Protonotaria. GeотнlyPex contains Geothlypis and Oporornis.

ICTERIEA contains Icteria.

Vermivores contains Helwitherus.

Sylticoled contains Seinrus and Dendroeca.

Setophagex contains Myiodioctes, Cardellina, and Setophaga.

We will ourselves divide the family into 3 sub-families:

\section{Sub-family a SYLVICOLIN $\circledast$ True Warblers}

Size small or not large; bill short, slender, and conical typical of the family, in fact, and generally with rictal bristles; wings trpical and longer than the tail excepting in Geothlypis; tail nearly if not quite eren and not conspicuously large or wide. (Hook of bill, and notch when present, very inconspicuous.) Nostrils free from bristles.

The True Warblers, this sub-family was formerly called Wood Warblers, in distinction from the Ground and Swamp Warblers of Audubon and other writers, ) are, then, the most 
difficult of all the members of the family to separate into genera and species, and to accurately determine; yet they are not so difficult as would seem at first sight for all that. The genus Siurus (or Seiurus as it used incorrectly to be called) alone would seem to stagger the novice. Why should it be placed here? The reason for this will appear later on.

"Keys" without number have been invented as "infallible guides" for the determining of the genera and species of our American warblers; most of these are worthless, as they deal either only with the adult males, or with adult specimens, or the migrant dress, or with partial states of plumage: But it must be remembered, that with most of our species the "dress" of the male differs from that of the female, and that of both male and female from that of the young-of-the-year bird; again, the spring dress often differs from the fall dress, and both or all together from that of the summer or breeding plumage. In any event, the student had far better deal with characters that will decide the genus and species, under any circumstances, than to fill his head with partial characters that eannot always be relied on.

Genera, Mniotilta, The Creeping Warblers (2 species).

Parula, The Blue Yellow-backed Warbler (with 3 species).

Protonotaria, The Prothonotary Warbler.

Helmintherus, (same as Helminthotherus and Helmitherus) The Worm-eating Warbler and ally.

Helminthophaga, or Helminthophila, allies of the Tennessee Warbler (12 species).

Peucedramus, The Olive Warbler.

Dendroeca (often spelled Dendroica) The True Warblers (25 or 26 species).

Siurus (wrongly Seiurus) The Oven Birds (4 species).

Oporornis, The Connecticut Warbler and ally.

Geothlypis, The Ground Warbler.

[Siurus, at one time regarded an almost typical thrush, agrees with the Warblers in nearly every important particular save that of size alone].

Sub-Genera, Helonox is often made a sub-genus of Helmintherus, for the accommodation of Swainson's Warbler; Perissoglossa, often used as a distinct generic name, is really a sub-genus of Dendrøca, and used for the Cape May Warbler. 
The young student will have his hands full if he attempts to follow the synonymy of the genera and species of this or of any other large family of North American Birds. The question of to-day is, what is? not so much what used to be?

\section{Sub-family $b$ ICTERIIN 1 Chats}

This sub-family seems to be framed for one genus and two species. It has been, by some authorities, put with the Warblers, from which it differs in its large size, huge bill (for a warbler), long and rather broad tail, short wings, and absence of rictal bristles of any kind. The commissure is strongly curved, and the whole bill much compressed. It is different from any of the other members of the family, and really ought to stand apart from them. It might, with propriety, be called the "Mountain Warbler." Excepting the bill, it much resembles a very large Geothlypis. It is, however, a true Warbler and has usually been always classed with the Warblers.

Genos, Icteria, (2 species).

\section{Sub-family c SETOPHAGINAE Flycatching Warblers}

The Flycatching Warblers are at once distinguished from the True or Wood Warblers. Their name implies their difference, which is especially noticeable in the shape and size of the bill. In size they restmble the True Warblers, as also in shape and general appearance of the wings and tail. The nostrils are, however, quite covered by the long bristles at the base of the bill, the tip of which is strongly hooked and notched. The base of the bill is depressed and broad, somewhat like that of a Hycatcher, and reminding one strongly of that bird. To a novice the illusion is complete, especially when these birds are actirely employed in catching insects. Yet they are, except in this one particular, warblers strictly, and have nearly all of the characteristics of True Warblers. The Setophaginæ have been placed in various relations with the uther birds of the family, though recent writers agree, pretty generally, in placing them after the Icteriince. 
Genera, Myiodioctes, The True Flycatching Warblers (5 species).

Cardellina, The Red-faced Warbler.

Setophaga, The Redstarts (3 species).

The generic names of the Warblers seem to be pretty generally accepted, and to be without equivalents either in generic or sub-generic terms. The mere fact of a genera having a synonym does not necessarily give it a right to a place in our system without sufficient other reasons. Only when a species differs essentially from the type of the genera, can it receive the designation of sub-genera. When two or more writers of equal merit differ in their naming, and reasons for naming, any given genera, and when each review the past field and state their reasons for the change, do we feel justified in giving to both names a generic equivalence. This does not make either name a synonym of the other, strictly speaking, unless, by mutual or universal consent or a more complete knowledge of the species, one writer is proved right and the other wrong in his premises, or one for any reason takes the preference of the other.

\section{FAMILY X COEREBIDAE THE HONEY CREEPERS}

Derivation seems uncertain

This family is distinguished at once from the last, which it very closely resembles, by the peculiar character of the bill, - and in this respect it greatly resembles the Certhiidoe or Creepers. Though its generic name, Certhiola, is said to be a " diminutive of Latin certhia, a creeper," I can find no derivation for the family name. It belongs in the tropics, and is not usually regarded as strictly a North American native species. It might be rightly called the Creeper Warbler.

Genos, Certhiola.

The exact position of this curious bird cannot be stated, at present, with any degree of positiveness, and authors have placed it at different times in very different relations. It appears to be a straggler here representing a single species. 


\section{FAMILY XI TANAGRIDAE THE TANAGERS}

Derivation not certain. The latest German authorities say "from the portuguese tangara"; the tangarine is a species of orange, so may refer to the color; the name of a city in Greece.

This is another group for whose family name I can find no satisfactory derivation, and whose precise position would seem somewhat uncertain. It resembles both the Warblers and the Finches, and would seem to stand, naturally, between them - but then where should we put the intervening groups? Such families as this show the advanced student how unsatisfactory our present classification really is.

The characters of the family are very marked: The form of the bill (like that of a finch or sparrow) with the peculiar tooth in the center of the edge of the upper mandible; nostrile small, rounded, and basal ; tarsus scutellate; and wings with 9 primaries. Being a tropical family the North American species are few.

Genos Pyranga, The Tanagers (2 species). [Both Wilson and Audubon give the genus name Tanagra, corresponding to the family designation].

Some writers plaee the Mexican straggler Euphonia in this family; but others connect the Corebida with the Tanagers by means of it. We see no reason for giving it any furtber special mention, it being an extra-limital form.

\section{FAMILY XII HIRUNDINIDAE THE SWALLOWS}

Latin hirundo, a swallow.

The exact position of the Swallow family, like that of many others, is not, at present, satisfactorily settled. Some place it before and some after the Vireos and Shrikes. 1t is one of those groups which, like a good many others, shows us how next to impossible it is to arrange the divisions of the BIRDs in anything like a continuous line of ascending and descending likenesses, and so give color to the tree-theory or rather tree-representation which is so often used to express the various relations and inter-relations of all groups of both Animal and Tegetable Kingdoms. For the present, we must be con- 
tented with their present position. The peculiaritits of the family are striking. Few could mistake the general appearance of a Swallow: The long, pointed wings; the delicate yet stiffened feathers of the tail ; the little legs, feet, and toes; the short, wide and compressed bill, give the familiar features of a Swallow at first sight. More particularly, we have: wings of 9 quills, nicely graduated from the first, which is the longest, to the last, which is about half the length of the first; tail usually forked more or less, outer feathers often very long; bill short, broad, and compressed, with deep gape; nostrils various in the different groups and usually without rictal bristles; feet small and weak ; tarsus scutellate (in front), feet weak but claws strong. The head and mouth resemble very strongly those of the Goatsuckers and Swifts.

Genera, Hirundo, The Barn Swallow and allies (4 species).

Cotyle, The Bank Swallow (2 species).

Progne, The Martins (2 species).

Sub-genera, Iridoprocne, Tachycineta, Petrochelidon, of Hirundo; and Stelgidopteryx of Сотуце. Noте. - Stelgidopteryx often assumes the position of a true genus, but we do not think that its similarity to $\mathrm{CO}_{0}$ tyle and its dissimilarity to the other swallows will properly admit to this.

\section{FAMILY XIII AMPELIDAE THE WAXWINGS}

Greek ampelion, "a diminutive singing bird, species not determined, doubtless one of the 'Motacilloe' the 'Warbler tribe' that frequent vineyards; hence the name ampelos, a vineyard."

Were this family comprised of the Waxwings alone there would be little difficulty in disposing of it satisfactorily ; but the species which, for want of a better place, are associated with them render the whole group one very difficult to manage, at least in respect to its position. It is pretty generally conceded to have three sub-families, which, however, agree in having the : bill short, stout, compressed, and wide at base, tip notched ; rictal bristles, if any, few and short ; basal portion of toes more or less joined to each other. The species of the family are so few that they are easily studied individually. The common Cedar Bird is a good type of the group. To 
trace the various positions which these species have, at different times, occupied would be a work for the specialist. We will not change them from their usual order.

\section{Sub-family a AMPELIN A Waxwings.}

Always known by the even tail with its wax-like appendages (except in rare cases and usually immature specimens). Genus, Ampelis, (2 species). [Synoxym, Bombycilla].

\section{Sub-family $b$ (Ptiliogonidinæ), (Ptilogonydinæ), and} (Ptilogonatinæ),

have all been used to designate this group, sometimes with and sometimes without other members of the family.

Genera. Phainopepla, The Black-crested Flycatcher. (Occurs also under the names of Phonopepla, Ptilogonys, and Cichlopsis, all valid as GENERIC specifications).

\section{Sub-family $c$ MYIADESTIN $\pi$}

Genus, Myiadestes, The Townsend's Solitaire.

It will be noticed, in the study of the individual, that Subfamily $a$ is very distinct from the Sub-families $b$ and $c$. As

Sub-family $a$. Wings with first quill spurious or nearly so ; tail short; frontal feathers extending beyond the nostrils, and rictal bristles absent.

Sub-families $b$ and $c$. Wings with first quill one-half (or nearly so) that of the other long quills, tail long; frontal feathers not extending beyond the nostrils, and rictal bristles present.

This combining of the Sub-families $b$ and $c$, as above, usually results in three genera :

Ptiliogonys, Cichlopsis, and Myiadestes.

The first two of these are, really, valid as distinct and separate GENERA, and not as mere synonyms for each other, although often so used.

The species of Sub-families $b$ and $c$ are, by some authorities, still placed with the Thrushes or near them. 
The affinity of any of the species of this family with the Flycatchers is, now, entirely out of mention; though Myiadestes does somewhat resemble them, thus supposedly involving the other members of the family, the relationship is much nearer to the Shrikes. We feel justified, however, in our present disposition of them.

\section{FAMILY XIV LANIIDAE THE SHRIKES}

Latin lanius, "an executioner."

Bill very strong, stout, and powerful, - basal two-thirds greatly compressed and wide at the base; tip hooked quite abruptly and distinctly toothed and notched; tail long, and with each pair of feathers, from the center or longest ones, smaller than the preceding pair; primaries 10, the 1st about one-half the longest; tarsus scutellate in front and on sides. Genus, Lanius, (4 species). (Collurio or Collyrio are synonyms).

\section{FAMILY XV VIREONIDAE THE VIREOS or GREENLETS}

Latin vireo, "a kind of bird, according to some the Green-finch."

It is only within a few years that the Vireos have been separated and isolated from the Shrikes. They were formerly made a second sub-family of, and secondary to, the latter. If we compare a Vireo with a Shrike it will be readily seen that the former is a diminutive of the latter, to all appearances: The bill is smaller, more cylindrical and less compressed though still notched and toothed - and the tail is not graduated but even and short; wing of 10 primaries, though the 1 st is often rudimentary and somewhat displaced, and at other times very short and somewhat spurious (often called spurious); size small ; tarsus scutellate in front and not on the sides.

Gends, Vireo, (16 species).

Sub-genera, Vireosylvia, and Lanivireo.

Many of the Vireos formerly appeared under the generic name of Lanius, but this only serves to show their former connection with the Shrikes proper. 
Note. - Both the Shrikes and the Vireos would seem, at first, to resemble several other families, more especially the Flycatchers, but a few moments consideration will convince one of the great gap that lies between the two, and show how distinct and individual they really are.

\section{FAMILY XVI FRINGILLIDAE THE FINCHES SPARROWS ETC}

Latin Fringilla, "the chaffinch."

The Fringillidoe are, without doubt, the largest and the most complex family with which the student will have to deal, in his study of Ornithology, though the character of a Finch or of a Sparrow would not easily be mistaken. Next to them, on the American contineut at least, come the Sylvicolidae, of which we have already treated. Their numbers are immense, their forms varied - often greatly and curiously so - and they are distributed so universally in almost every possible and conceivable location, as to render them, at once, among the most familiar objects of the animate creation in any given location. Sparrows and Finches occur everywhere throughout North America, in greater or less numbers, at all times of the year: As migrants, replaced by distinct and separate species at different times of the year, as summer residents, and again as winter visitors and residents of still different species and varieties. All sorts of localities have their peculiar species. Their food is varied and almost anything that comes in their way, though, for the most part, consisting of grains and seeds. They are, generally speaking, gregarious - often going about in immense flocks, especially in the spring, fall, and winter. Most of them are fine singers; and their colors, with a few exceptions, are modest and somber.

The family is well characterized, in general, by the old-time name for the group of "Conirostres" or cone-bills, or the coneshaped bills. Though few people would mistake the general form, shape, and contour of a Finch or Sparrow, yet to define properly the family were a very difficult thing to do. It were 
easier to say what birds were "fringilline" in their character than to give the reason therefor. It is as difficult, also, to say exactly where, in the natural sequence of the family, each species should be placed. There are species in other families, and even whole families, which so greatly resemble the Fringillidæ as to leave the question still an open one, as to whether or no they should rightly be placed with them. We adopt, however, the seemingly best adapted definition for the whole group meagre and unsatisfactory as it is :

Bill short, stout, conical, and tapering abruptly to the sharppointed tip from a base whose diameter, in either direction, is, very frequently, nearly if not quite as great as the length of the whole bill. The bill itself forms the best means of characterizing the family. Tarsus scutellate in front, undivided on the sides, and ridged behind; wings with nine primaries only; tail with twelve feathers: the size and shape of both, however, are subject to almost endless variations. The angle of the commissure at the base of the bill is often made the prominent characteristic of the family - but this does not seem as decided throughout all the species as the general cone shape of the bill itself. The nostrils are prominent but uncertain in position, shape, and general appearance and general surroundings; the rictal bristles, also, are not constant.

I have found it very advantageous to the student, in this group especially, as well as in many of the others, to have him or her secure one or several typical forms, then write out a careful analysis of their chief characteristics - even going into minute particulars. He can, with this as a guide, compare his other genera with it and note how they deviate from this type. The Song Sparrow, the White-throated Sparrow, or the Purple Finch, are good species for this purpose.

The attempts to arrange this family into sub-families have been so intricate and unsuccessful that we shall not enter into a discussion of the question here.

Professor Baird's separation of the Finches is of especial 
interest and well worth a great deal of very careful study. It is not intended to be strictly scientific, being more a natural grouping of like with like; yet it will not be very difficult to compare it with our present systems of classification, as, for the most part, the genera treated of and named are of the same equivalence as our present cnes.

\section{"Family Fringillido.}

I divide all the United States species into 4 sub-families, briefly characterizable as follows:-

1. Cоссотнraustin ж.-Bill variable, from enormously large to quite small; with the base of the upper mandible almost always provided with a close-pressed fringe of bristly feathers (more or less conspicuous) concealing the nostrils. Wings very long and pointed, usually one-half to one-third longer than the forked or emarginate tail. Tarsi short.

2. SPIZELlin E.-Embracing all the plain-colored, sparrowlike species marked with longitudinal stripes. Bill conical, always rather small; both mandibles about equal. Tarsi lengthened. Wings and tail variable. Lateral claws never reaching beyond the base of the middle claw.

3. Passerellinæ-Dparrow-like species with triangular spots beneath. Legs, toes, and claws very stout; the lateral claws reaching nearly to the end of the middle ones.

4. Spizix e.-Brightly-colored species usually without any streaks. Bill usually very large and much curved; lower mandible wider than the upper. Wings moderately long. Tail variable.

Under sub-family 1 we have,

A.-Bill enormously large and stout; the lateral outline as long as that of the skull. Culmen gently curved.

Gexcs, Hesperiphona. 
B.-Bill smaller, with the culmen more or less curved; the lateral outline not so long as the skull. Wings about onethird longer than the tail or a little more; first quill shorter than the second. Claws considerably curved and thickened; hinder one most so, and almost inappreciably longer or even shorter than the middle anterior one. Tarsus shorter than the middle toe. Lateral toes unequal.

Genera, Pinicola, Carpodacus, and Chrysomitris.

C.-Hind claw considerably longer than the middle anterior one, with about the same curvature; claws attenuated towards the point and acute. Lateral toes about equal. Wings usually almost one-half longer than the deeply forked tail.

A.-Points of mandibles overlapping.

Genos, Curvirostra.

B.-Points of mandibles not overlapping.

Genera, Egiothus and Leucosticte.

D.-Hind claw much the largest; decidedly less curved than the middle anterior one. Tarsi longer than the middle toe. Lateral toes equal; reaching about to the base of the middle claw. Hind toe as long or longer than the middle one. Bill very variable; always more or less curved and blunted. Tail slightly emarginate or even. Wings one-half longer than the tail. First quill as long as the second.

Genus, Plectrophanes.

Under sub-family 2 we have,

A.-Tail small and short; wings considerably or decidedly longer than the tail, owing either to the elongation of the wing or to the shortening of the tail. Lateral toes shorter than the middle, without its claw. Species streaked above and below.

A.-Thickly streaked everywhere above, on the sides, and across the breast. Wings pointed, longest pri- 
maries considerably longer than the secondaries. Tail forked.

Genera, Centronyx, Passerculus, and Poocetes.

B.-Moderately streaked above, on the sides, and on the breast; the dorsal streaks broader, the others fainter, than in the last. Wings short, reaching a little beyond the base of the tail. Not much difference between the primaries and secondaries. Tail short, graduated, and the feathers lanceolate, acute.

Genera, Coturniculus and Ammodramus.

B.-Tail longer and broader; nearly or quite as long, sometimes a little longer, than the wings, which are rather lengthened. The primaries considerably longer than the secondaries. None of the species streaked beneath, and the back alone streaked above.

A.-Tail rounded or slightly graduated.

Genera, Chondestes, Zonotrichia, Jnnco, and Poospiza.

B.-Tail decidedly forked; a little shorter than the wing, sometimes a little longer.

Genus, Spizella.

C.-Tail lengthened and graduated; decidedly longer than the wings, which are very short, scarcely extending beyond the extreme base of the tail. Feet reaching but little beyond the middle of the tail. Species all streaked above; streaked or nearly unicolor beneath. No white on wings or tail. Outer lateral toe the longer. First quill not the shortest of the primaries.

Genera, Melospiza and Peuccea.

D.-Tail rather short, and much graduated; longer than the wings: the midrib more median. Culmen curved. Tarsus considerably longer than middle toe. Outer toe longer. But little difference in the length of the quills; the outer ones 
much rounded; even the second quill is shorter than any other primary except the first.

Genus, Embernagra.

Under sub-family 3 we have simply the genus Passerella.

Sub-family 4 contains,

A.-Tail decidedly shorter than the wings ; nearly even.

A.-Bill elongated; upper mandible rather deeper, or as deep as the lower. Feet large and strong.

Genera, Calamospiza and Euspiza.

B.-Bill stouter, and more curved above; upper mandible generally not so deep as the lower. Feet smaller.

Genera, Guiraca and Cyanospiza.

B.-Wings and tail of the species about equal in size.

Genus, Spermophila.

C.-Wings much shorter than the tail, which in broad and graduated; primaries graduated; the first seldom longer than the secondaries.

A.-Head crested. Prevailing color red. Bill red. Genera, Pyrrhuloxia and Cardinalis.

B.-Head not crested. No red. Bill dusky.

Genus, Pipilo."

The North American genera and species of the Fringillida, at least the most prominent ones, may be briefly enumerated as follows:

Genera, Hesperophona, The Evening Grosbeak.

Pinicola, The Pine Grosbeak. 
Pyrrhula, The Cassin's Finch (or Bulfinch).

Passer, The House and Mountain Sparrows, [imported and Naturalized from Europe,] (2 species).

Carpodacus, The Purple Finches (3 to 6 species).

Loxia, The Crossbills (3 species).

Leucosticte, The Rosy Finches (5 species).

Agiothus, [sub-Genera, Linota, The Linnets. Red-poles, etc. (5 species).

Chrysomitris, The Pine Finch or Linnet.

Astragalinus, The American Goldfinch and 5 others.

Plectrophanes, The Snow Bunting.

Centrophanes, The Longspurs (3 species).

Rhynchophanes, The Bay-winged Longspur.

Passerculus, The Savanna Sparrow (8 or 9 species).

Poocetes, The Grass Finches (2 species).

Coturniculus, The Yellow-winged and Henslow Sparrows or Buntings (4 species).

Ammodramus, The Sea-side and Sharp-tailed Finches (4 species).

Melospiza, The Song and Swamp Sparrows (9 species).

Peucœe, The Summer Finches, (7 species).

Amphispiza, The Sage Sparrows (3 species).

Junco, The Snow-birds ( 8 species).

Spizella, The Chipping Sparrows and allies (7 species).

Zonotrichia, The White-throated Sparrow and allies (6 species).

Chondestes, The Lark Finches (2 species).

Passerella, The Fox Sparrows (4 species).

Calamospiza, The Lark Bunting.

Spiza, The Black-throated Bunting and ally.

Zamelodia. The Rose-colored Grosbeak and ally.

Guiraca, The Blue Grosbeak.

Passerina, The Nonpariels or Painted Finches (5 species).

Pyrrhuloxia, The Texas Cardinal.

Cardinalis, The Cardinal Red-bird and ally.

Pipilo, The Towhee Buntings (12 species).

Embernagra, The Texas Sparrow.

A comparison of the most recent writers, in fact of a majority of writers, for the past fifty years, fails to show any very great deviation from the above generic names - as to the form and spelling of the name. Many of the species assigned to these genera are rare, and either Alascan, Texan, or Mexican forms. Again, a few of them may be somewhat questionable. A large number of them are, really, mere geo- 
graphical varieties of some given type form. Taking all these facts into account, we can easily imagine, and in reality prove, that nearly every genera possesses a typical representative of that genera. The shifting of species from one genera to another, though strictly in accordance with a commendable spirit sometimes unwisely persistently manifested however to arrange the species thus typically under their appropriate genera, must be studied under the direction of some competent authority or looked for in the various tables of SYNONYMS which are given by so many of our ornithological writers.

It were not a part of our plan to characterize the genera of our North American birds. To simply mention them in what we consider their best systematic position, for the present at any rate, were enough for our purpose here.

\section{FAMILY XVII ICTERIDAE THE BLACKBIRDS STARLINGS ORIOLES and GRACKLES}

Latin icterus, "a yellow bird." Greek ikteros.

This is one of the most familiar and attractive of the families of North American birds. Old and young turin to it with pleasure and delight. The number of species is not great; but they are distributed everywhere, and their well-known forms are looked for with eager expectations, each year, throughout the length and breadth of our land. It is also a very satisfactory family with which to deal scientifically, as it is well defined and definitely grouped. Its likeness to the Fringillidce is, however, in many important respects, very close; yet a glance at the general form of the birds, the bill, and the general coarseness of the plumage, will at once show a difference, between the two - notwithstanding the fact that both retain the 9 wing primaries and the angulated commissure to the bill. The bill conforms to the Corvido, and is in general nearly or quite as long as the head; it is long with sharp edges rather than short with dull edges, and is unnotched at the tip; rictus without bristles. Legs strong and stout. As a rule the tail and wings are rather long in propor- 
tion to the body of the bird, yet the difference between them and the Corvidee is a permanent one and quite well defined. There are four sub-families, all perfectly natural ones.

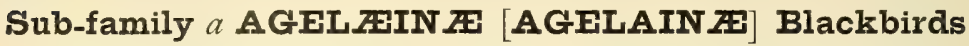

This sub-family is known as the Blackbirds, in distinction from that of the Grackles which ase also called blackbirds but wrongly so - strictly speaking. The distinction might perhaps be better preserved by calling the present sub-family the Swamp Blackbirds, as the name much better illustrates the characteristics of its various members. These birds are among our most familiar early Spring arrivals, and in later Spring and late Autumn swarm in thousands and one might almost say tens of thousands, doing immense damage to the grain fields of the farmer. The type, the Red-winged Blackbird, is familiar to every one at all acquainted with the blackbirds. It is hard to give characters that will determine absolutely, from a scientific standpoint, either with or without the specimen before one, the peculiar features of the group. We are obliged therefore, with this as with so many other families, to select a typical specimen, describe it, and compare with it, and the student will soon form his own distinguishing characteristics. Bill, feet, and general plumage, however, have an appearance not easily mistaken. The main sure feature is that the bill is not longer than the head. The genera are separable from each other with great distinctness. There are four genera, all quite constant. The predominant color is black.

Genera, Dolichomyx, The Bobolink.

Molothrus, The Cowbirds (3 species).

Agelceus [or Agelaius], The Swamp or Marsh Blackbirds (3 species).

Xanthocephalus, The Yellow-headed Blachbird.

These genera are without sub-genera or synonyms of any importance, as are also most of the other genera of the family.

Sub-family $b$ STURNELLIN / Starlings

The well-known single representative of this sub-family 
(with its few varieties) is called indiscriminately the Starling and the Meadow Lark; but by whichever name it goes it is always distinguishable by its yellow breast and streaked back, and by its bill which is always equal to or much longer than its head, coupled with the peculiar stiffness of its tail feathers. These birds are well-known features of our meadows all the Spring, Summer, and Autumn.

Genus, Sturnella, The Meadow Larks (3 species).

\section{Sub-family $c$ ICTERIN $巴$ Orioles}

This is another sub-family created for a single genus, yet of sufficient prominence and distinction to be so treated. The Orioles are not, however, with a single exception, as familiar universally as many others of the family. The Orchard Oriole, for instance, will often escape most careful search even in localities where it is a common summer resident, and must be searched for carefully to be detected at all. While the Blackbirds and the Grackles are eminently gregarious, the Orioles and the Starlings are not so strictly speaking. Again, in the two former groups the bill and the legs are both stout and strong; in the two latter (especially in the Orioles) they are weak and slender. In the Orioles the bill is not longer than the head, and the claws are strongly curved as is not the case in the other three sub-families. The plumage, also, serves to distinguish them.

Genes, Icterus, The Orioles (8 species).

Oriolus might, by some, be regarded as a sub-genus, by others a distinct genus, but we see no reason to use the name at all at present, it is misleading and involves species in other sub-families. We simply note it to answer an otherwise pertinent inquiry.

\section{Sub-family $d$ QUISCALIN $\nRightarrow \quad$ Grackles}

The Grackles strongly resemble the true Blackbirds, and their predominant color is black. The peculiar gloss of the 
plumage and blackbird-like bill and claws are present, yet there is a distinction. The bill is as long as or longer than the head, the legs are long, the tail is long, and, comparatively, the wings are short; were there no other characteristics these alone would be sufficient to distinguish the group. The careful study of the bill will show other well-defined differences. The two genera are constant.

Genera, Scolecophagus, The Rusty Blackbirds or Grackles (2 species). Quiscalus, The Crow Blackbirds or Grackles (6 species).

\section{FAMILY XVIII CORVIDAE THE CROWS AND JAYS}

Latin corvus, the raven.

Few persons would mistake a Crow for any other bird, yet, strange to say, when we come to consider the family to which it belongs, and all the members of that family, we are again baulked, as in many other instances, for a precise definition of it. This only shows, more conclusively than ever, how truly defective a great deal of our classification really is. The number of families which individuals of the Crow family closely resemble is very great, and we have not space to enter largely into this subject. If you define the Titmice you describe a miniature Crow or Jay; if, on the other hand, you judge merely by resemblance, at a little distance, your Crow becomes a gigantic Grackle; yet, technically even, nobody would ever think seriously of combining any of the individuals of either family with those of the other.

The general characters of the Corridce are: Bill stout, regularly tapering to its acute point and not longer than the head, and altogether a very typical bill; nostrils more or less concealed by tufts of stiff bristly feathers which are directed forwards towards the tip of the bill; tarsus scutellate in front and grooved; wings of ten primaries, with the first about half the second in length; tail of twelve feathers and, though varying greatly in shape, is generally rather long and always rounded or graded. Aside from these characters, the general 
appearance of the group is not easily to be mistaken. There are two sub-families, though it is rather difficult to positively define either of them. The shifting of the species has been noticeable in both genera.

\section{Sub-family a CORVIN 7 True Crows.}

Bill long and equal to head; tail barely rounded and much shorter than in sub-family $b$; wings rather long and flattened, longer than the tail.

Genera, Corvus, The True Crows and Ravens (6 species).

Picicorvus, The Nutcracker Crow.

Gymnocitta, The Blue Jay-Crow.

It is a source of great satisfaction that modern writers have not tangled up the good old name of Corvus, at present, however, we go no farther than genera; Gymnocitta is also spelled Gymnokitta.

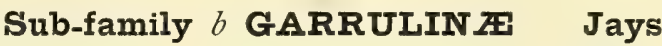

Bill shorter than head; tail long and much rounded or more or less graduated; wings shortened and outwardly somewhat convex, equal to or shorter than the tail.

Genera, Psilorhinus, The Brown Jay.

Pica, The Magpies (2 species).

Cyanocitta, The Blue Jays (5 species).

Amphelocoma, The Crested Jays (5 species).

Xanthura, The Green Jay.

Perisoreus, The Canada Jay and allies (5 species).

Cyanurus (or Cyanura) and Garrulus are, in the main, simply srsoNYMS for the JAY family in general, exclusive of the Magpies. The names, especially that of Cyanurus, is even now preferred by many writers.

There seems to be no well defined SUB-GENERA.

The student must compare these two sub-families thoroughly, by means of specimens, and strive to find, if possible, more fixed characters than the present ones which will conform for all the members of each.

The European Starling has been reported as having "Straggled to Greenland in one known instance." It belongs to a genus Sturnus, and some writers give it a position in our North 
American fauna ; but the probability of its having been an escaped specimen, or brought over to this country in some ship, or otherwise "straggled" from its own peculiar habitat, literally, is at once suggested. It is not strictly then an American bird, and should not yet be recorded as such.

\section{FAMILY XIX TYRANNIDAE THE FLY- CATCHERS}

Latin tyrannus, a despot, a tyrant.

The Flycatchers form what is known as the group of songLEss, in distinction from the singING, Passerine Birds. Set off from the great mass of SINGING BiRds, in a group by themselves, one would naturally expect that the distinguishing characteristics of this single family would be so marked as to be instantly recognized. Here again we are brought face to face with the incompleteness and inconsistencies of our present classification. The fact that any specimen we may have before us is a "true flycatcher" alone settles our point indisputably.

Among the essential qualifications for being a member of the Clamatores, as given by most of our writers at present, is the number and state of development of the singing or. laryngeal muscles. It has been told us that the Oscines have four or five pair of distinct laryngeal muscles; and that the Clamatores are known by having less than four pair of laryngeal muscles: Yet no less an authority than Audubon tells us distinctly that the Nuthatches have "a single pair of large inferior laryngeal muscles," and includes his Ptilogonys (our Myiadestes) and his Culicivora (our Polioptila) in his group of Flycatchers under the distinct understanding of having no intrinsic muscles to speak of. We give these examples of " differences of opinion" to excite further investigation into our complex groups - not to perplex the student - and to show a few of the apparent inconsistencies with which even our present classification seems burdened.

The general appearance as well as the general habits of a 
Flycateher are familiar to any one. The general scientific characters are as follows: Bill length of head or shorter, flattened or compressed more or less for its whole length, broad at base, tip fine and sharp, abruptly hooked at end and notched, and with its edges nearly or quite straight; mouth, when open, large and wide; a few bristles at base of bill; nostrils round and situated at the end of the oblong fossæe, when present; the tarsus is peculiar, it is scutellate (scutellæ small) all around and with a deep grove where the plates join; feet small and, for the most part, weak when compared with the general activity of these birds; tarsus about equal to the middle toe and its claw ; wing of ten primaries, of which the first is often the longest, and never spurious or under size, - the outer quills subject to a greater or less degree of emargination on their inner webs towards their tips; tail of twelve feathers, deeply forked or nearly even.

Most of the Flycatchers are more or less crested, and this crest they can raise or lower at will. 'Being strictly insect feeders most if not all their food is captured while on the wing. They are excessively nervous and agile creatures, seldom remaining long in any one place but constantly darting about, now here and now there, and performing most surprising evolutions while on the wing in search of food. When at rest the peculiar and constant jerking of the tail, as if for the purpose of balancing itself, is very noticeable. The frequent and loud snapping noise produced by the quick closing of the mandibles, is also a prominent peculiarity of these birds.

The North American Flycatchers are, ordinarily, separated from the world-wide group of Flycatchers by a sub-family TYRANNINÆ. This may seem necessary to some; but we fail to see any reason why it should be thus forced upon us, without any explanations, as is done by so many or our ornithological writers of to-day. We shall dispense with the usual sub-family, and then the above family characteristics will answer equally well for our present purpose. The explanation that our classification is a universal one, while our fauna is North American, seems a very one-sided one. 
Genera, Myiozetetes, Giraud's Flycatcher.

Pitangus, The Derby Flycatcher.

Myiodynastes, Henshaw's Flycatcher.

Milvulus, The Swallow-tailed Flycatchers (2 species).

Tyrannus, The Tyrant Flycatchers (5 species).

Myiarchus, The Crested Flycatchers (5 species).

Sayornis, The Pewee Flycatchers (3 species).

Contopus, The Olive-sided Flycatcher and allies (4 species).

Empidonax, The Least Flycatcher group (10 to 12 species).

Ornithion, The Small-billed Flycatcher.

Pyrocephalus, The Vermilion Flycatcher.

Several other species, mostly rare or perhaps extra-limital, may yet be accorded a place in our North American fauna.

A number of synonyms for many of the above genera, and even individual species, are so far obsolete that we do not need to recall them at the present time. Neither do we recollect any well-founded sub-genera, or changes in generic signification, that need be further added here.

FAMILY XX CAPRIMULGIDAE

THE GOATSUCKERS

Latin caprimulgus, "a goatsucker. "

The name Goatsucker is more truly a tropical than a North American name. Our species are, for the most part, called Whippooruills, and Nighthauks, and written either as one name or with each syllable separated. There are but few species in the family, and these are not easily mistaken for members of any other family. The general appearance of any one individual represents very well all the others.

The general characters of the family are: Bill very small, depressed, triangular-shaped, somewhat curved, culmen very small but gape inmense; nostrils situated near the base of the bill, round, uncovered, and more or less tubular - that is, raised above the level of the surrounding parts and rounded. Tarsus short, rather weak, and partly feathered above, feet small and weak, very short, the middle toe rather long and all scutellate above, the anterior ones connected with a small web at their base; wings long and pointed, of ten primaries; tail rather broad and of ten feathers. Whole plumage soft, fluffy, and more or less greasy to the touch. The above characters 
are as near representing the typical species as can be well given in a short space, and will be found correct in the main. The species are almost nocturnal, preferring twilight to either day or night. Owing to the elasticity and lightness of their plumage their flight is swift and almost noiseless.

There are two sub-families, both well defined and valid, but only one of them belongs to our fauna, and thus the characters of the family answer equally well for us here. The genera are as follows:

Genera, Nyctidromus, The Parauque Goatsucker.

Phalcenoptilus, Nuttall's Poor-will.

Antrostomus, The True Whippoorwills (3 species).

Chordeiles, The Nighthawks (4 species).

Sub-Gends, Caprimulgus of Antrostomus.

Some writers make these both separate genera, but the species are so very similar that whichever one finally stands for the genus the other can only take $s u b$-generic rank.

\section{FAMILY XXI CYPSELIDAE THE SWIFTS}

Probably from the Greek kupsele, "a species of swallow."

The Swifts, at least some of them, were formerly regarded as true Swallows and included iu the genus Hirundo, but that was years ago ; to-day we see the difference, and a vast difference it is. The well-known Chimney Swift, or Swallow as it is often called, is typical of the family. So well known is this species that very little need be said in general regarding the members of the family. The group is akin to the one which precedes it, and can be placed naturally next to it. The bill is very small indeed and strongly resembles that of the Whippoorwills in miniature with a correspondingly large gape; but while there is an apparent notch at the end of the bill in the former, however, there is none in the Swifts and the bristles also are wanting; the nostrils also are exposed and barely reached by the feathers at the base of the bill, they are elongated not round; feet small and weak and skinny, toes nearly equal and without basal membranes - the hind toe more or less abnormal and versatile; wings of ten feathers, long, nar- 
row, and pointed, and when the bird is at rest overlapping each other behind; tail of ten feathers, which are more or less stiffened and with the mid-rib extending beyond the feathered portion in some species. There are 2 sub-families.

\section{Sub-family $a$ CYPSELIN $¥$ True Swifts}

The tarsus and toes being feathered.

Genus Panyptila (or Cypselus), The White-throated Swift.

\section{Sub-family $b$ CH开TURIN叛 Swallow Swifts}

The tarsus and toes unfeathered and naked.

Genera Nephoecetes (or Cypseloides), The Black Swift.

Chotura, The Chimney Swifts (2 species).

\section{FAMILY XXII TROCHILIDAE THE HUM- MING BIRDS}

Probably Latin trochilus, "a very small bird, perhaps the Golden-crested

Wren" ; Greek trochilos a name used for the "wren."

This is another group easily distinguishable from any other family, at least of North American birds, and, except to follow out our plan, it would not be necessary to minutely define it here. Though similar to the Swifts in many respects they are, in reality, unlike any other family with which we shall have to deal. The family, however, presents a variety of features which are similar to those in other families - individual features, that is - for instance: the wings resemble those of the Suifts; the base of the tongue curves back behind the skull, as in the Woodpeckers; with other peculiarities of structure corresponding more or less closely to those of still other families.

Humming Birds are peculiar to the continents of North and South America. Though mostly tropical, their variation in shapes of bill, wings, tail, plumage, as well as in general coloration, is something extraordinary and remarkable. Their food consists in great measure of insects, with a strong admixture of the honeved sweets of the flowers about which they so continually horer. The exclusively North American species are few and much similar in appearance. 
In general : the bill is usually long, curved in a variety of directions or straight, slender, pointed, and generally from one-third to one-half the length of the whole bird; nostril slits with a scale covering them and generally more or less feathered, without rictal bristles; wing like that of a miniature Swift, of ten feathers (1st generally the longest), small, scythe-shaped, and very powerful for so small a bird; tail variable, of ten feathers ; feet small, weak, and, with the tarsus, altogether peculiar. Our species are, for the most part, four inches or under in length, which shows their comparative smallness. Many species of the insect tribe surpass them in size. The student will find great pleasure in making special study of this delightful family, and it will afford him unexpected enjoyment. We have no sub-families to present.

Genera Eugenes, The Refulgent Humming-bird.

Trochilus, The Ruby-throat and ally.

Selasphorus, The Rufous Humming-birds (3 species).

Calypte, The Anna Humming-bird and ally.

Atthis, The Heloise Humming-bird.

Stellula, The Calliope Humming-bird.

Calothorax, The Lucifer Humming-bird.

Amazilia, The Dusky-tailed Humming-bird and ally.

Basilinna, The Xantus Humming-bird.

Iache, The Circe or Broad-tailed Humming-bird.

[Calypte amce was formerly Atthis Anna, and C. costce A. costce].

Selasphorus formerly went under the genus Trochilus, but wrongly as the genera are quite distinct.

The shifting of species from one genus to another is rare in this family. The above are all stable genera and species, but no doubt others will be discovered in Southwestern North America.

\section{FAMILY XXIII TROGONIDAE THE TROGONS}

Greek trogo, "to grind with the teeth," "especially nuts and fruit."

The family of the Trogons is a tropical one and very characteristic. The best general impression of it may be taken from comparison with any single representative specimen. As its name implies its bill is well suited to ' grind nuts and fruit with the teeth, being very powerful and with a toothed edge. 
The general appearance of both bird and plumage is peculiar and unmistakable. There is but a single individual included in our North American fauna, yet this is enough to characterize fully the family. It has the, Bill broad, stout, short, and with the tip hooked and dentate; the antrose feathers at base extending over the nostrils; tarsus broadly plated and concealed by the feathers; feet small, weak, and with the inner anterior toe reversible; wings short, convexed, and more or less falcate-shaped; tail of twelve feathers, long, and broad. Genus Trogon, The Copper-tailed Trogon. One species without synonym.

Some authorities give the Momotus (or Motmot) a position in the fauna of North America. It is known instantly by the long, slightly curved, serrated-edged mandibles, and the long central tail feathers; the feet are "syndactyle." (These birds have been also associated with the Alcedinidce, which they resemble strongly).

\section{FAMILY XXIV ALCEDINIDAE THE KING- FISHERS}

Latin alcedo [alcyon], Greek alkuon [HALcrox] "the kingfisher."

This is another family easily distinguishable at sight. It is one, also, difficult to place with accuracy ; yet the same general similarity of many of its important features with other birds of the ORDER associates them, and we cannot reject the likeness. They come naturally in their present position, although high authority has associated them with the Clamatores, as well as AFTER the Woodpeckers. They are a familiar feature of water scenes, and their harsh, rattling cry not easily mistakable. Their general characteristics are: Bill usually longer than head, strong, straight, tough and hard, and like a somewhat compressed cornucopia rery sharp at the tip and with immense gape; lower part of tibia bare, tarsus reticulate plainly in front and like the feet small and weak, the toes more or less united at their base, inner toe very short; wings of ten primaries, long compared to the rest of the body, with third quill generally the longest; tail of twelve feathers, short 
and broad but with feathers small and slender. The typical bird will supply many features at a glance that can be depended on for all the members of the family wherever they are to be met. The American sub-family is sufficiently characterized by the above family definition.

Genus Ceryle, (2 possibly 3 species).

Synonym Alcedo.

\section{FAMILY XXV CUCULIDAE THE CUCKOOS}

Latin cuculus, "a cuckoo."

The Cuckoos form another of those anomalous groups, of which we have so many, which are at once difficult to place with accuracy and hard to characterize satisfactorily. The forms usually placed in this family are strangely varied, and, but for certain technical characters, would hardly be supposed to belong to the same order even. There are about six American species, and yet they have been placed in THREE distinct sub-families.

The family of the Cuckoos agrees with that of the Woodpeckers and the Parrots in having the feet disposed in pairs, two being anterior and two posterior (zygodactyle), it being the "fourth" toe which in this case is reversable. In respect to other distinguishing marks we have: Bill about the leugth of the head, barely curved, and slightly compressed; toes short compared to the length of the tarsus. And here we must stop, as it is impossible to proceed any farther with satisfaction. The remaining external features are so different in the different sub-families which have been formed of the group, that we must let them speak for themselves. It was formerly attempted to treat these sub-families as genera, but in view of the peculiarities of form, the constancy of the characters, and the relation to the universal family of Cuculidoe, our best writers to-day have decided upon retaining the sub-family in each case. Upon comparing the species, the student will without doubt justify this decision. 


\section{Sub-family $a$ CROTOPHAGIN $¥$ Anis}

Tail of eight feathers; bill short, compressed, and high, and altogether marked and peculiar, once seen not easily forgotten ; nostrils near the centre of the base of the upper mandible, exposed, oblong, and upper mandible curved down over the under; wings about the length of the body and slightly concaved; tail long and graduated; face naked.

Genus Crotophaga, (2 species).

None of these birds are common, though the species are numerous, even in tropical countries where they mostly reside. They live on the ground.

\section{Sub-family $b$ SAUROTHERIN $\#$ Ground Cuckoos}

Tail of ten feathers; bill about equal to the head, still compressed and with the upper mandible curving over the under, stont though slender; rictus with bristles; tarsus long and toes strong though still small, scutellate (both toes and tarsus); nostrils much less rounded than in $a$; wings much as in $a$ though even shorter than the body or not longer, and more concaved; tail long, narrow, and graduated. This, like the former, is a rare group as well as a peculiar one. Face feathered.

Genus Geococcyx.

\section{Sub-family c COCCYGIN I True Cuckoos}

Tail of ten feathers; bill a little shorter than the head, stout growing more slender towards the acute tip, curved noticeably, and compressed; nostrils as in $a$ and $b$ but oblong; face feathered; tarsus and feet fitted for living among the trees and not on the ground as with $a$ and $b$, and weak; wings longer and more pointed than in the other groups (relatively to the size of the body, that is); tail long, broad, graduated.

Genus Coccygus.

Syxosтm Cuculus.

Two species of this family, only, are everywhere distributed in Torth America, at least in the United States, and common; they are the Black-billed and Yellow-billed Cuckoo. 


\section{FAMILY XXVI PICIDAE THE WOODPECKERS}

Latin picus, a woodpecker.

The Woodpeckers constitute the last, really the first and characteristic, family of this ORDER. Familiar, as well as peculiar, and universal, this group possesses especial interest to all lovers and observers of our birds. Few have received more or more careful study and attention, or are more interesting, than the Woodpeckers. Various as have been the classifications of these writers the simplest, as is often the case, have proved the best and we have come back to them. One family and a few genera serve well our purpose. Should we enter into a careful review and revision of the field of past and present systematists, it would occupy far too much space. - And every one knows what a Woodpecker is. They are found in all parts of the world (with one or two rare exceptions). Their food is largely insect life - principally larva, or what the farmers often calls "worms." The tappings made in garden trees by these birds are usually made to secure some concealed grub, which would otherwise damage the tree much more if let alone. They appear to seldom touch or injure a sound tree. The prejudice against them which some, even very intelligent, farmers possess to-day is wrong and almost wholly unfounded. They are eminently beneficial.

In general the features of the family are: feet disposed in pairs, two being anterior and two posterior (zygodactyle) the "fourth toe" being reversed; tail feathers acuminate with the shafts elastic and very stout, of twelve feathers, outer pair very small; wings of ten primary quills, the first being almost spurious; tarsus and toes with scutellæ in front, more or less reticulate behind - both tarsus and feet are, comparatively speaking, short, small, and weak, yet possessing remarkable strength and tenacity, the toes also are remarkably pliant, the claws strong, sharp, much curved, and very tough; the bill is peculiar, being straight, stout, somewhat compressed, with an awl-like, truncate tip, and is a veritable chisel. The special study of this feature alone would be productive of much in- 
terest. The tongue of most of these species sends terminal shoots around the base of the skull by means of which it can throw that member out to a very great length, and with its horny, rasp-like tip secure grubs and insects from far within the interior of the tree upon which it is in search of food. One genus has but three feet. The student will do well to make a careful and separate study of this family, and he will find his interest in it increase as he progresses.

The family is generally divided into three sub-families, but only one of them is exclusively American. In consequence the family characteristics will stand for those of the sub-family Picina.

Genera Campephilus, The Ivory-billed Woodpecker.

Hylotomus, The Pileated Woodpecker.

Picus, The Hairy Woodpecker and 9 to 12 allies.

Xenopicus, The White-headed Woodpecker.

Picoides, The Three-toed Woodpeckers (3 species).

Sphyrapicus, The Yellow-bellied Woodpecker (and 3 allies).

Centurus, The Red-bellied Woodpecker (and 3 allies).

Melanerpes, The Red-headed Woodpecker (and 4 allies),

Colaptes, The Flickers (5 species).

As these genera are all stable, and, at present, no sUB-GENERA or sYNovYMY seems to be desirable, we shall not try to puzzle the student by attempting to account for old generic forms. The family does very well as it is. Picoides, alone, seems to depart from the family characterization. A study of its embryonic forms would be highly interesting.

\section{FAMILY XXVII PSITTACIDAE THE PARROTS}

Latin psittacus, Greek psittake, a parrot; probably from their hissing or chattering (sizo to hiss).

As there is but a single family of these curious birds, and a single American sub-farnily, moreover but a single genus, in referring back to the characterization of the ORDER, the student will find plenty of marks by which to determine the real position of the group. Lntil recently there were accorded us but a single species, now we can innumerate two genera and three species. They all conform to the same general type.

The curious bill, hawk-like and yet not hawk-like; the peculiar disposition and shape of the feet, being disposed in 
pairs, two anterior and two posterinr, the "fourth toe" being reversed (zygodactyle), as in the Woodpeckers and the Cuckoos, and few if any other birds, we can determine the specimens referable to this family with absolute accuracy. The general form of the Parrot is a familiar one. That parrots should be so rare now in North America, when formerly so abundant at least in the Sonthern United States, is remarkable. The ORDER has anatomical peculiarities, also, which are fully as remarkable as their general appearance. It is one upon which a great deal of time may be satisfactorily used in study. We have two genera:

Genera Rhynchopsitta, The Thick-billed Parrot.

Conurus, The Carolina Parakeet and ally.

The above two genera and three species, owing to the paucity of forms in this ORDER, are included here, - one genera and two species occur South of the limits of the United States proper. Conurus carolinensis, The Carolina Parakeet, alone represents the species common north of Mexico.

\section{FAMILY XXVIII ALUCONIDAE THE BARN OWLS}

"Italian alocho, some kind of owl," probably akin to Latin alucinor.

Strange as the arrangement may appear, at least to the uninitiated, we find that the majority of writers of to-day agree, almost unanimously, in separating this curious Owl-anomaly from the great mass of Nocternal Birds of Prey by a separate and distinct family. Writers have for a long while been aware that its peculiarities showed it to be different from the other Strigides. Until recently writers were in the habit of placing it last instead of first on the owL list. Its present place is not, as might at first seem to appear, from any desire to place all the owl species in a reverse order from the usual one. This new position results more from the fact that this species is more typical of the Universal Order of STRIGIDES, perbaps, than any other of our North American species. Be this as it may, the general position as first seems now almost universally acknowledged. The single family, genera, and species, referring directly to our common American Barn Owl, is instantly recognizable. 
Although we have styled our family Aluconid s, and our genus Aluco, it is the same as Professor Baird has styled,

"Sub-family STRIGINE. - TyPICAL OWLS.

Size medium, never very large. Head large; facial disc perfect; bill rather long; eyes rather small for this family; [STRIGID e, The Owle] legs rather long, fully feathered to the toes. Strix, Linn.

Head large, without ear tufts; eyes rather small; facial dise perfect, and very conspicuotis; wings long; tarsi long; tail rather short; toes and claws rather long. This genus contains about twelve species from all parts of the world.

\section{Strix pratincola, Bonaparte}

The Barn Owl."

Our present writers agree in making Aluco the name of the genera.

\section{FAMILY XXIX STRIGIDAE OWLS IN GEN- ERAL}

Latin strix, Greek strigx, "a screech owl."

This family has been characterized very fully under the $\mathrm{Or}$ der and Sub-order RAptones. It is a family not easily mistaken under any circumstances. The main difference between the Strigidce and the Aluconidee is principally an anatomical one: The universal characteristics of the OwLS remain the same, outwardly, with very little difference. I have given Professor Baird's characters for Aluco, but as he has treated it as a sub-family under a general heading of "Family STRIGID.E," his family characters must necessarily include characters which will answer equally well for both our Aluconidæ and our Strigidæ. This might prevent our using his Family Strigidæ characters for our Family Strigidæ characters. And yet, as may be seen from above, the real difference is very slight and chiefly an anatomical one. So, as a purely technical matter, we find ourselves in a real quandry for a proper diagnosis for our present Family. Many writers make no sub- 
families of our American Owls, but treat only with generic differences.

Professor Baird's admirable classifications, however, are not old, and are still authority. As we have adopted one part of them we cannot do better than adopt the remainder, for the Owls at least. We shall quote the parts we borrow.

\section{Sub-family $a$ "BUBONIN 2 Horned Owls}

Head large, with erectile and prominent ear-tufts. Eyes large ; facial disc not complete above the eyes and bill; legs, feet, and claws usually very strong."

Genera Bubo, The Horned Owls (4 species).

Scops, The Little Screech Owls (8 species).

Asio, The Eared Owls (2 species).

The present Asio stands for the recent Otus and Brachyotus, while both of these latter generic names formerly received the generic equivalent of Strix. Neither of the three latter names seem to be used now either as a SUB-GENUS or in the sense of our present genus Strix.

\section{Sub-family $b$ "SYRNIN $\#$ Gray Owls}

Head large, with very small and concealed ear-tufts, or entirely without. Facial dise nearly perfect; eyes small for the family of Owls; wings rather short, or not so long as in the preceding; tarsi and toes generally fully feathered."

There are both large and small Owls here as in $(a)$.

Genera Strix, (5 species).

Nyctale, (2 species).

It is now pretty generally conceded that at present the name Strix appears appropriate as the genus for the five species which formerly went by other generic names. Some of these are still in good standing as generic, but whether they could any of them be called even sub-generic, or should simply remain as generic equivalents = sYNonyms, is a matter very much of individual opinion. We should doubt very much the propriety of using any of them in a $s u b$-generic sense. Professor Baird used the name Surnium for both the Great Gray and the Barred Owls; Professor Ridgeway used Strix for the Barred Owl and its varieties only. He used Vlula for the Great Gray Owl and its varieties. 


\section{Sub-family $c$ "ATHENIN I Bird Owls}

Size small ; facial dise very imperfect, or nearly obsolete; tarsi generally partially or but thinly covered with feathers; head without ear-tufts." These are all small Owls.

Genera Glaucidium, The Pigmy Owls (2 species).

Micrathene, The Elf Owl.

Speotyto (Spheotyto [wrongly]), The Burrowing Owls (2 species).

As originally constituted this sub-family contained only Athene, (a sYNoNYM for Speotyto ; ) and one species of Glaucidium. If we admit Micrathene as a sUB-GENERA of Glaucidium, which seems to us perfectly justifiable, we still come within the preseribed limits of the $s u b$-family.

\section{Sub-family $d$ "NYCTEININ $\nexists \quad$ Day Owls}

General form compact and robust. Head moderate, without ear-tufts ; wings and tail rather long ; tarsi strong, which, with the toes, are more densely covered than in any other division of this family." These are large and medium-sized Owls. (Surnia agrees well with Asio in point of size).

Genera Nyctea, The Snowy Owl.

Surnia, The Hawk Owls (2 species).

We see no reason why, with the above separating distinctions, the Family STRIGIDE should very greatly perplex the student. It surely gives him all the elementary facts for a working elassification, at once correct and up to date. Upon this basis he will find it comparatively easy to enlarge his knowledge of the classification of the family, and to add much thereto from his own investigations.

\section{FAMILY XXX FALCONIDAE THE FALCONS HAWKS AND EAGLES}

Latin falco, Greek phalkes; a falcon.

The main distinguishing characters of this family are much the same as in the Sub-order of the RAPTORES on page 29. We shall point out the differences in the Sub-families here so fully that there will be little need to enlarge upon the family. It would be a matter of some difficulty, indeed, to do otherwise. As some families are known best by the individuals 
placed in them (as evinced in the Order PICARI E, ) so others, like the Owls, Hawks, etc., are best known by their sub-families. (And they, likewise, by the individuals placed in them). Many writers are now making a separate family of the Fish Hawk or Osprey ; perhaps the wisdom of this is as evident as that of constituting a separate family for the Barn Owl. As we treat the one we will so treat the other. In general : a Hawk, a Falcon, or an Eagle, are easily to be told at sight or with but very little difficulty. The general appearance is not easily to be mistaken. The hooked bill, the fierce eye, the head, wings, tail, and general appearance of the body, are all characteristic, and striking the eye at once give an unmistakable impression. Even the dead bird and the dried skin bear with them the form, appearance, and general air of a dead warrier. The flight is powerful, "and bears out well the general character of the bird. The foot of a Hawk is also a notable characteristic - the sharp, curved, and strong claws could not easily be mistaken for those of birds of any other family.

The Sub-families of the FALCONIDE are as persistent and as well defined as in the STRIGID \&. The are as follows:

\section{Sub-family $a$ CIRCIN 叛 Harriers}

The Marsh Hawk, our only representative of this sub-family so far, is a familiar and well-known bird. It differs materially from any other of the hawks, and yet approaches the Kites from which, on a first inspection, it would seem to be the farthest removed of any of the lesser hawks. It has the bill less powerful than the other species with which it was formerly associated, and it is neither notehed or toothed at the tip; the tarsus is long and slender, and the feet and claws comparatively weak as well as slender ; cere prominent; nostrils large and oblong; rictal bristles many, curving, and long; head large; face with a partial disc much as in the Owls ; ears prominent ; wings long and pointed ; tail long and broadening towards the tip. The difference in the plumage of the male and the female often confuses a novice into the sup- 
position that he has discovered a new species - the male being bluish in color and the female and young brownish - all have the RUMP WHITE, this alone would characterize the subfamily and distinguish it from any other.

Genus, Circus, The Marsh Hawk.

The old generic equivalent was Falco.

\section{Sub-family $b$ MILVIN 死 Kites}

In most instances the Kites would be known at once by their long and often deeply forked tail, though a few species do not have the tail abnormally long. The tail and wings would alone characterize the sub-family. Compared with the Circise: bill rather slender, weak, and not toothed at the tip ; no facial dise ; bristles few or wanting altogether ; upper mandible sometimes barely notched the under one never; wings long and pointed; length of tail varied; tarsus not very long and feet small, claws slender - the whole foot weak. The student will find that the genera vary considerably among themselves, yet all conform to the general Kite-like outline. He will do well to compare his specimens and form his own diagnosis of the group in that way.

Genera, Rostrhamus, The Everglade Kite.

Ictinia, The Mississippi Kite.

Elanus, The White-tailed Kite.

Elanoides, The Swallow-tailed Kite.

Srnonyms, (the most important ones): Milvus of ELANus, and Nauclerus of ELANOIDES. Several synonyms, hardly worth mentioning in the present connection, will doubtless occur to students of synonymology; especially that of Falco, which occars for all four species.

\section{Sub-family c ACCIPITRIN 7 True Hawks}

We call the Accipitrix玉 the True Harks in distinction from the Buteosix are really "True Hawks," though why the latter family is so almost universally styled the "Buzzards" would be hard to say. To call them "Buzzard Hawks" might indeed be eminently proper, as they partake of the characteristics of both 
True Buzzards and True Hawks. The former are more proj= erly "Partridge or Chicken Hawks." The Accipitrin are slender built hawks, though in courage equal to Eagles themselves. Their flight is swift and sure ; and they pursue their prey with a heedlessness and blind obstinacy, regardless of obstacles, that is often their own ruin. They often secure their prey only to dash themselves to pieces against some building, window, or other obstruction which lies in their path. In general they have: Bill short, stout, untoothed though curved and of irregular outline (edges); nostrils oval, slightly oblonged, without central tubercle; legs long and rather slender, scutellate, and rarely feathered; wings short, concaved, and powerful, first quill short, third to fifth longest ; tail long, feathers broad, end of tail square, rounded, or often emarginated. The general appearance of being long and slender rather than short and stout distinguishes them at once.

Genera, Accipiter, The "Sharp-shinned" Hawk (2 species). Astur, The Goshawks (2 species).

Accipiter and Astur were both formerly classed with Falco, a moment's glance, however, will show the different appearance of the two families; but, to look at the synonymy of our Hawks and Eagles, one would think that there was formerly but one family for all, $i$. e., FALco.

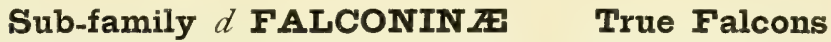

The Falcons proper are historic birds, and their appearance is striking and unmistakable. They are found in all parts of the world, have been referred to by writers as far back nearly as the art of writing itself is known, and gives a character to the whole family which is partaken of to a greater or less degree by every individual in it. Yet they differ in appearance from the members of all the other sub-families. They have the bill supplied with both tooth and notch, (the bill alone would characterize the sub-family and furnish a study in itself, a single glance will give a better impression of it than pages of descriptive matter); cere prominent; nostril circles with central tubercle and placed near the crown of the cere; tarsus and toes rather short but very stout, and more or less 
fully reticulate, tarsus feathered, middle toe noticeably longer than any of the others, claws all stout, tough, and are sharp, typical talons; wings long, strong, pointed, and very powerful, well fitted for an arrow-like, cutting flight, first four quills long and often emarginate on the inner webs; tail short, fanlike, and rather powerful and strong. The whole bird gives one the general idea of its being the embodiment of concentrated power, and it is fierce and relentless in its pursuit of its prey. There is properly but a single

Genus, Falco.

Sub-genera, Hierofalco, The Gryfalcons (5 species).

[Falco, The Falcons proper (3 species)].

Esalon, The Merlins (4 species).

Tinnunculus, The Sparrow Hawks (5 species).

[T. fusci-carulescens is frequently called Rhynchofalco fusci-ccerulescens.] These sub-genera are often given the rand of genera.

\section{Sub-family $c$ POLYBORIN $\nRightarrow$}

Caracara Eagles

The genus Polyborus, for which this sub-family has been framed, is a curious mixture of the Vulture and the Eagle, and through the latter of the "Buzzard Hawks"; anatomically, also, it is related to the Falcons proper. We do well, therefore, to give it a decided individual character. In Professor Baird's Report he has classed them as following the Fish Hawk (genus Pundion) which follows the Bald Eagle (genus Halicetu*i); both of these, with Polyborus, are classed under the sub-family containing the Eagles. In describing Polyborus, he says: "Smaller than in either of the preceding genera of Eagles. (Pondion and Halicetus.) Bill rather long, compressed; cere large ; wings long, pointed; tail moderate or rather long; tarsi long, rather slender; claws long, rather weak, and but slightly curved; space in front of and the eye naked." These birds are evidently restricted to Southern North America, and may differ somewhat from the common South American species.

Genus, Polyborus (2 species). 


\section{Sub-family $f$ BUTEONIN \& Buzzards or Buzzard Hawks}

Some of our writers make a distinction between the Buzzards or Buzzard Hawks, (placing them in different sub-families,) and the Eagles, while others do not. While it is true that there are certain forms in either group that grade toward each other, the main body of each differ in so many particulars that we shall regard them as separate sub-families and treat them as we herewith do.

The Buzzard Hawks are easily and naturally grouped together, though having peculiarities of several of the other sub-families of the family. Their stout, robust, and heavy form and appearance stands out prominent against the longer and more slender form of nearly every rival. They differ from the FALCONIN $x$, in that the nostrils are not circular and have no central tubercle; from the Accipitrin 2 , in that the tip of the wings is formed by the third or fourth or fifth quill or any two or all of them, and that the tail is uniformly at least one-third smaller than the wings (in Accipitrin 2 the sixth quill enters into the tip of the wings and the tail is equal in length to the wings), and the tarsus being short and stout and usually more or less feathered; from the PoLyborine, by their general size and shape; and from the Eagles by their shape, size, and generally subdued figure and less fierce aspect, and from the fact that the extrenities - bill, legs, feet, and claws, long-pointed wings and the tail - seem more in keeping with the birds here enumerated than to be out of proportion [long, sharp, slender, and pointed] with the body, as in that group. An Eagle, however much it may resemble in certain features the BuTEONInÆ, would never, at second glance, be mistaken for one of them. There are few members of the group that would not be immediately recognized as belonging to this sub-family.

Genera, Antenor, Harris's Hawk.

Buteo, The "Buzzard or Hen Hawks," (14 species).

Archibuteo, The Rough-legged Hawks (2 species).

Asturina, The Mexican Goshawk. 
Urubitinga, The Mexican Black Hawk.

Onychotes, Gruber's Hawk.

Antenor is merged in Buteo by some writers, we confess that we cannot see why in view of its record as a new genus.

\section{Sub-family $g$ AQUILIN $\boldsymbol{A} \quad$ Eagles}

The Eagles would be sufficiently distinguishable from the sub-family preceding them (the ButEonINÆ) by their mere size alone, provided size were a proper character for so high a division as that of a sub-family. When we add the long, slender, falconine shape of the body, and extremities even; the strongly curved and sharp-pointed bill and talons; the compressed basal half of the upper mandible - in distinction from the rather short, stubby, and slightly inclined to depressed base in the ButEonine-; and the difference in shape of the feet in the two groups when spread out and the bird is standing upon them - in the Eagles the ends of the toes raising themselves considerably above the base of the tarsus; we are satisfied that these sub-families are and should be made distinct. The North American families are few, and easily determined.

Genera, Aquila, The Golden Eagle.

Haliaetus, The Bald Eagle and ally.

Thrasaétus (or Thrasyaetus), The Harpy Eagle.

\section{FAMILY XXXI PANDIONIDAE THE OSPREYS}

Latin Pandion, a king of Athens.

The Ospreys or Fish Hauks are made a separate family from the FALCONIDE, (they are usually made a genus under the Eagles, which they very closely resemble in many particulars,) chiefly through the reversibility of the outer toe, (which is not reversible in the FALCONID.£, ) and the curious plumage or rather state of plumage which these birds are known to possess. They resemble, in various ways, several groups: The bill is much like the Eagles, but shorter; the wings like the Falcons, but rather heavier about the shoulder's ; the body like the Buzzard Haurs, but more slender; and yet all of its 
characters are so individual as to place it justly by itself, and and yet none of them seem to exactly resemble those of the other groups above alluded to. It is a family hard to define precisely, and yet a glimpse of the bird is sufficient to fix it at once in the memory. There is but a single genus and a single species common, at least in North America.

Genos, Pandion, The Fish Hawk or Osprey.

Though placed between the Falconid 2 on the one hand and Cathartide on the other, they can in no way be called a link between the two, as Pandion differs materially from any form of either.

\section{FAMILY XXXII CATHARTIDAE THE VULTURES}

Greek kathartes, "one who purifies."

The American representatives of this family are not difficult to determine or to characterize. Their peculiar form and shape makes them at once conspicuous and easy of recognition. There being no necessity in America for sub-family divisions, and but a limited number of genera and species, the family characters will be the same as those enumerated under the SUB-ORDER heading on page 29. The fact that they feed exclusively, or nearly so, upon carrion, however, would not of itself prevent a strictly scientific or technical difference; it would be rather a peculiarity of the species. The bare space on the head and neck; the curiously-shaped bill - long and weak and hooked at tip ; large nostrils ; and strong, long, and wide wings; are enough to determine the family wherever it may be found.

Genera, Pseudogryphus, The California Condor.

Cathartes, The Turkey Buzzard.

Catharista, The Black Vulture, Carrion Crow.

Vultur was formerly a generic equivalent for all of the above names, but it is now seldom employed.

It is strange if these three species of Vultures, without varieties, be all that occur within our borders. One or two additional species (or varieties) may yet be found on our Southwestern borders, but they are still unrecognized. 


\section{FAMILY XXXIII COLUMBIDAE THE PIGEONS}

Latin columba, a dove or pigeon.

This is another family whose characteristies would be the same as those of the SUB-ORDER; but as there is but one suborder, to obriate the necessity of falling back upon the ORDER we will represent the family characters as of, primarily, a general domestic pigeon- or dove-like appearance; the bill is not easy to describe, but the inspection of the bill of a domestic pigeon will give at once the main noticeable characteristic of the family ; the head is small, the body plump and comparatively large (or full); the tarsus differs essentially in the different sub-families, as will be shown below; wings long and pointed, broad and somewhat concaved at the shoulder (almost poverful and capable of long-continued flight); tail varying - rounded or almost square - and often with graduated feathers (showing most plainly from beneath); the plumage remarkably soft and somewhat greasy to the touch. In fact, they are simply pigeons - wild pigeons, and dores - wild doves; and conform in apperience much more satisfactorily than in exact definition. There are three sub-families :

\section{Sub-family $a$ COLUMBIN 9 True Pigeons}

Tarsus feathered and scutellate; feet small ; tarsus short; wings rather long, flat, and pointed.

Genera, Columba, (3-species).

Ectopistes, The Passenger (Common Wild) Pigeon.

\section{Sub-family $b$ ZENAIDIN P True or Ground Doves}

Tarsus not feathered but scutellate; feet medium in size; tarsus alsu medium; wings rather short, concaved, and barely pointed.

Gexera, Engyptila, The White-fronted Dove.

Zenaidura, The Carolina Mourning Dove and ally.

Zenaida, The Zenaida Dove.

Melopelia, The White-winged Dove.

Chamapelia, The Ground Dove (2 species).

Scardafella, The Scaled Dove.

Geotrygon, The Key West Dove. 


\section{Sub-family $c$ STARNGNADIN 死}

Tarsus not feathered and reticulate; feet large; tarsus long; bill short and stubbed; wings much concaved at shoulder.

Genus, Starnonas, The Blue-headed Dove.

The above genera are, at present, almost uniformly stable and without synonyms. Zenaidura was not formerly used exclusively for the Carolina Dove. Turtur was formerly used for several of the Doves. Columba was an old generic name for nearly all of the above genera.

The wings and tail vary so as characters that they can hardly be relied on except for generic distinctions.

\section{FAMILY XXXIV CRACIDAE THE CURASSOW GUAN}

Derivation uncertain.

The Texas Guan or Curassow is a bird most curious and individual in its character. The single species recognized at present is made the type of a genus and a family, as well as of a SUB-ORDER, among the North American birds. Its position is, however, somewhat uncertain - being placed in the Order Columbe by some writers, and in Galline by others. The student should be careful not to fall into the error, on this account, of regarding it as a "link" between these two orders as it has no such relation and could therefore occupy no such supposable place. The curiously " naked narrow streaks," Baird (Gray) - of the throat (wattles absent); the naked tarsus (scutellate), and short hind toe; the slender bill; the crested head; the curious shade of olivaceous of its plumage; and the short wings for the length of the bird [wing $8 \frac{1}{2}$ inches and length 23 inches]; furnish sufficient characters to more than determine the family as well as its present single member. More species may doubtless yet be discovered probably in the South-western part of North America.

Genus, Ortalis, The Texan Guan or Curassow.

(Ortalida $=$ also Ortalis). 


\section{FAMILY XXXV MELEAGRIDAE THE "WILD" TURKEYS}

Latin Meleagris (Greek similar) "a Guinea hen."

This family needs no special technical definition in order that the young student may identify its members. In the present instance the family, sub-family, and specific diagnosis would be the same. The curiously naked head and neck with its warty outgrowths (caruncles), the fleshy "dew-lap" [or laps], the breast "tassel," the spurs of the male, and the general appearance of the plumage, all bear indisputable testimony to the characteristics of the Turkeys. We have at present but one genus, and two possibly three species.

Genus, Meleagris, The Wild Turkey and ally.

$($ Gallopavo $=$ also Meleagris $)$.

\section{FAMILY XXXVI TETRAONIDAE THE PAR- TRIDGE GROUSE AND QUAIL}

Latin tetrao, Greek tetraon, a heatheock, moorfowl.

This family is one of such especial interest throughout the length and breadth of our land that it is worthy of more than passing mention. Probably to no family, at least among the LAND BiRds, is more geueral attention drawn than to this one. The distinctions between the Grouse, the Partridges, and the Quail, are "fine points" in ornithological science; and it is sufficient here to say, that the scientific and the popular significations for the individuals in question are often greatly at variance. We shall endeavor to give the student only the correct technical scientific equivalent for each species - and then people may call them what they please to suit their owu convenience. This family constitutes the great majority of the Land Game Birds of North America - and its species are found North, South, East, and West: everywhere in this our grand old continent. The woods, the plains, the mountain regions, and the prairies, are alike inhabited by members of this family. Formerly, the Grouse and the Quail were made separate families; but this does not seem necessary, for the 
difference between them is apparently greater than it really is. To make them sub-families under one family, seems more in keeping with the general scientific character of the separate individuals in question. As a family, however, they are very hard to characterize. The peculiar "plumage," or rather state of plumage, being its most constant character. The feathers are, for the most part, short, broad, elastic, soft, fine, yet remarkably strong and stout - this renders the plumage soft, close-fitting, water-proof, barely greasy to the touch, dove-like, and of a neat, trim appearance not possessed by any others, in the same degree, whether Land or Water Birds. We shall separate the members of this family into two subfamilies, as follows :

\section{Sub-family a TETRAONIN I Grouse}

Tarsus wholly or in part feathered; feathers extending also into the groove of the nostrils. The Grouse are of a much larger size than the Quail; here size alone being another constant character.

Genera, Canace, The Canada Grouse and 4 others.

Centrocercus, The Sage Cock.

Pediocetes, The Sharp-tailed Grouse (2 species).

Cupidonia, The Pinnated Grouse and ally.

Bonasa, The Ruffed Grouse (3 species).

Lagopus, The Ptarmigans (3 species).

Some of the species of Grouse have interchanged their genera, frequently, especially in former years; the old genus Tetrao stood then for almost any of the species. It is not at present used at all in America, but is confined to its proper European representatives.

\section{Sub-family $b$ ODONTOPHORIN平 Quail}

Tarsus naked and scutellate; nostrils unfeathered; toes also naked ; size compared with the Grouse small.

Genera, Ortyx, The Common Quail and 2 allies.

Oreortyx, The California Mountain Quail and ally.

Lophortyx, The California Valley Quail and ally.

Callipepla, The Scaled Quail.

Cyrtonyx, The Massena Quail. 
The genus (European) Coturnyx, The Messina or Common European Quail, is not a true native of North America but an introduced species, and very different from Cyrtonyx as above which is a native of the Southwestern United States.

Regarding the family in general: The individuals among the Quail also have changed genera somewhat, in former years, but not to the same extent as the Grouse. Tetrao also included some of the Quails. Perdix seemed to be the old favorite, however, but it is seldom referred to now.

The above characters for these two sub-families are to be fully relied on ; the individuals themselves will furnish other points of difference. The genera can be tetter characterized than the sub-families even, as each genera presents peculiarities in itself which do not, as is so often the case, combine to perplex the student with their similarity to each other in so many of their essential feetures. The above genera of both sub-families are stable and all we have at present. The generic names of the sub-families have changed but little in the past,fifty years, and are all probably good and stable.

\section{WATER BIRDS.}

The excellent diagnosis of the Limicolæ given by Professor Baird is so very useful in separating the different groupings of this division of the ORDER - this SUB-ORDER, in fact - that we copy it for the student, who can use it fearlessly and freely to give him a comparative view of the families contained therein and of their connection with each other. He divides the SUB-ORDER into two portions, each of which contains their respective families of which a brief outline is given :

"A.-Nostrils reaching usually to the end of the basal third or half of the commissure; oral, short. Bill contracted about 
the nostrils, where the culmen is more or less indented. Nasal groove closed obtusely and abruptly, or shallowing out broadly to the end. Hind toe generally wanting; neck short and thick.

Charadrid a.-Bill rather cylindrical, as long as the head, or shorter; the culmen much indented opposite the nostrils, the vaulted apex more or less swollen and rising, quite distinct from the membranous portion. Legs elevated; hind toe rarely present, and then rudimentary ; the outer and middle toes more or less united by membrane.

НжмАтоРоDIDж.-Bill as long as the head, or twice as long, compressed; culmen but little indented, and the bill not vaulted beyond the nostrils, which are quite basal.

B.-Nostrils narrow and fissured, not reaching beyond the basal fourth of the commissure. The bill attenuated and linear beyond the nostrils, not compressed nor indented around them. The nasal groove running out into a narrow, acute channel to or beyond the middle of the jaw, just above the edge of the bill; the forehead narrowed and depressed to the bill.

RECURVIROSTRIDA.-Legs covered with hexagonal plates, becoming smaller behind. Anterior toes all connected more or less by membrane. Bill much lengthened and attenuated the groove along the side of the upper mandible not extending beyond the middle. Gums denticulated only at the base.

Phalaropodid e.-Feathers of breast compact, ducklike. Legs with transverse scutellæ before and behind. Toes to the tips with a lateral margin, more or less indented at the joints, the hinder with a feeble lobe. Bill equal to or longer than the head, the lateral groove extending nearly to the tip.

SCOLOPACIDÆ.-Legs with transverse scutellæ before and behind, as in the last family, (except in Numeniece.) Toes not margined broadly to the tips, with or without 
basal membrane; hind toe generally present. Bill generally longer than the head, the groove extending beyond the middle."

The above characters will aid the young student. He will do well, however, not to confine himself too strictly to them, without looking for other determining characteristics for his family problems in this most perplexing group of interesting forms.

\section{FAMILY XXXVII CHARADRIIDAE THE PLOVERS}

Greek charadrios, Latin charadrius, a plover.

The vast extent, both as to territory and as to numbers, of the "Shore Brrds," as they are called, renders them at once a difficult and an interesting group of individuals to study. The varieties of classification to which they have been subjected, and the diversity of forms presented, are well calculated to perplex the student, though they present a most excellent field for research and careful investigation. We have, hitherto, been treating of the LAxD BIRDs exclusively: We now enter what is known as the province of WATER BIRDS. In the former case we found that the characters of the bill, the tarsus (rarely the toes and the wings to a small extent), and the tail, presented us with the main features of our classification; in the latter or present case, the feet - and toes and the wings, added to the bill and often peculiar shape of the head, will furnish perhaps the most prominent and striking determining characteristics. The bill varies about equally in both divisions.

Our first family, then, will be that of the Plovers. As our American representatives are included in a single sub-family, our characterization of them will answer equally well for subfamily or family diagnosis: Bill equal to or shorter than the head, somerthat Columbine in appearance at base, but more like a true bill at the terminal portion; nostrils a long slit 
deep in the soft membranous fossæ, which are oblong and very prominent - nostrils at the extremity of the fossæ - and gape very small; tarsus reticulated; hind toe very small or absent, middle toe much shorter than the tarsus, web at base cleft or not large ; wings long and narrowed, and reaching to or beyond the tail; tail rather short and nearly or quite even. General form rather plump and full. The genus Aphriza differs somewhat from the other genera by combining with its four toes, which have no basal web, a tarsus scutellate instead or reticulate in front.

The Charadridd are not exclusively "Sea Shore" birds. they are found inland as well where many of them breed.

Genera, Squatarola, The Black-bellied Plover.

Charadrius, The Golden Plover (3 species).

Egialites, The Ring-neck Plovers (8 species).

Podasocys, The Mountain Plover.

Vanellus, The Lapwing.

Aphriza, The Surf Bird.

SUb-Genera, [?] Oxyechus for the Killdeer, and Ochthodromus for the Wilson's Plover, might easily be regarded as sub-GENerA of Egialites. We should prefer such an arrangement rather than placing them as distinct genera in a group whose members show such apparently natural affinities. We see no reason why other and older synonymy, which is now for all practical purposes discarded, need trouble us.

\section{FAMILY XXXVIII HAEMATOPODIDAE THE OYSTER-CATCHERS AND TURNSTONES}

Greek aimasso, "to be bloody or blood-red," and pous, the foot; $=$ red-footed.

This second family of our Water Birds, though by no means so difficult to characterize as the former, is none the less interesting. They are exclusively "Shore" birds, and wade to the depth of their rather long, slender legs for shell-fish (bivalves) which they open with their stout bills. The family features are well set forth in the table at the beginning of this portion of cur work. It seems strange, perhaps, to set off the few species here into $s u b$-families, but they are sufficiently individual to admit of it. 
Sub-family $a$ HAEMATOPODINAE OysterCatchers

Tarsus less than bill, reticulate in front, outer toes with a barely apparent membrane, no hind toe; bill long, flattened, and prominent. Length over 12 inches.

Gexus, Hcomatopus, (3 species).

\section{Sub-family $b$ STREPSILAINAE Turnstones}

Tarsus longer than bill, scutellate in front, outer toes without membrane, hind toe present; bill short and pointed and not prominent. Length under 12 inches.

Genus, Strepsilas, (2 species).

These genera are all stable and without synonyms that need annoy us.

\section{FAMILY XXXIX RECURVIROSTRIDAE THE AVOCETS AND STILTS}

Latin recurvus, recurved; rostrum, a bill.

This is still another family whose peculiarities of structure at once determine its members with very little difficulty. It is not, like the former family, divided into sub-families; although the genera are very decidedly different from each other. The family, as a family, is at once known by the long, slender, and often extraordinarily recurred bill; the long, small neck; and the immense long, bare legs (tarsus and nearly the entire length of the tibia bare). Recurvirostre has four toes with complete webs and long and strongly recurved bill, while $H i$ mantopus has three toes almost wholly unwebhed and with bill much shorter and almost straight. The previous table will give further characters. Although "Shore" birds they are more abundant inland by fresh water.

Genera, Recurvirostra, The American Avocet. Himantopus, The Black-necked Stilt.

These two genera were formerly merged in one, Recurvirostra. Their position in the scale may at any time be changed, but the genera are stable. 


\section{FAMILY XL PHALAROPODIDAE THE PHALAROPES}

Greek phalaris the "coot," pous a foot; coot-footed.

This small family is sometimes placed near the end of the Shore Birds rather than near the beginning. The position we give to it, near its larger allies, seems to us more natural, and leaves nothing between the Snipes and the following ORDER. The family contains three genera of one species each. The main characters of the family have been given in the previous table, the other points of peculiarity are: feet lobate, toes with narrow membranes - with either plain or lobed edges; tarsus thin but wide. The general appearance of these birds is much like that of a small sandpiper, but the plumage is trim, close-fitting, and like birds that spend the greater part of their time in the water, as these do. The bill differs considerably in the different genera, as do also the feet. The birds are small, and are to be found, often in immense flocks, just off shore all along our coast and rarely in inland waters.

Genera, Steganopus, Wilson's Phalarope.

Lobipes, The Northern Phalarope.

Phalaropus, The Red Phalarope.

These genera are all quite stable, even hardly interchangeable, though all went formerly under the one name Phalaropus.

\section{FAMILY XLI SCOLOPACIDAE AND SANDPIPERS \\ THE SNIPES}

Greek skolopax, Latin scolopax, a woodcock or snipe.

This family is, without doubt, the most numerous and the most difficult with which the young student will have to contend among all the WATER Birds. It is, in fact, at least third if not second in importance in the whole Class. The general resemblance of the species will at once show that they belong to this family, but there are a good many individuals that will cause very great trouble to the beginner. The table placed at the beginning of this division will, in a great measure, help to remove the difficulties of identification; yet much will remain to be done, even with that aid, in guiding the stu- 
dent in right directions. The members of the family are easily distinguished from members of any of the families which have gone before; and the Rails, which are often wrongly made a $s u b$-family of this family, have decided peculiarities of their own at once prominent and stable. Perhaps the most important character of this and allied families is the bill. It is eminently adapted to the means employed by each individual species for the procuring of its food, and the legs and feet as well as the bill vary accordingly.

The members of this fanily are, in a very great measure, gregarious and migratory. Nearly every locality, along both the Atlantic and the Pacific coasts, has its restricted summer or breeding fauna of these individuals. They are of almost universal distribution: some being found along the sea-coast, some inland, and many in intermediate areas. People unacquainted with the habits of our birds are often surprised to find sea-coast birds far inland; but it is a well-known fact that many of our sea-birds, especially the snipes and sandpipers and gulls, follow up the course of our larger and even some of our smaller rivers and, at certain times of the year, are abundant along the meadows and river banks hundreds of miles away from the Ocean. The True Snipes (and also the Woodcocks) are found, in fact, more often in the bogs and the ditches inland than directly along the coast.

The more carefully the student studies the habits of this family, (as of all especially of migratory birds, in fact,) the more thoroughly will he become convinced that its members are influenced in their movements by well-defined laws, rather than chance as many seem to suppose. The laws which compel birds to seek food - giring us either extensive or limited migration - are entirely different from those which influence the domestic, seasonable, or daily economy of those same birds when inhabiting peacefully a region where food is abundant, and where they can act out the natural impulses of instinct. It was formerly supposed that, in a very great measure, this peculiarity of this species " happened," that peculiarity of that 
species "chanced." As we become daily more and more acquainted with the habits of our birds, we find that very little " happened" by " chance "; fixed laws govern everything, we might say, but lack of food. When the food gives out, the bird breaks loose from all apparent rule to seek food; when this is found its regular habits reduce it again to rule. The True Snipes and the Woodcock have been found, after a long study of their habits, to be creatures of fixed laws and habits. We are finding out, slowly, that these laws apply to other species as well. The more reason why the habits of birds should be studied more than ever before, and with an intensity of interest that may discover to us more of these laws. We venture to predict, that each species will be found eventually to possess an individuality of habit not before suspected. Thus we see that each species seems adapted to its mode of life, and a little study soon brings order out of confusion. Each genera groups itself according to similarity of habit as well as to similarity of structure. In the SCOLOPACID $\mathbb{E}$ is this especially true. It is for the young student to discover for himself what these habits may be.

Before entering upon an enumeration of the genera of the Scolopacide, it may be well to present to the student, for careful study, comparison, and general reference, the tables prepared by Professor Baird for this family. Though it presents but a partial review of the family, and was, like the previous ones, prepared some thirty-five years ago, its main features are still sufficiently useful to serve our present purpose in preparing for more extended tables if the student wishes.

\section{"Family SCOLOPACID ж.}

According to Bonaparte's arrangement, the ScolopaCid $\mathrm{E}$ are divisible into two sub-families - SCOLOPACIN $\mathrm{E}$ and Tringine; the former with one tribe, Scolopace 2 ; the latter with four, Tringine, Totanem, Limosine, and $\mathrm{NU}_{-}$ MENIN . The arrangement of Keyserling and Blasius and of 
Burmeister, however, seems more natural in associating TRINGex with Scolopacex under Scolopacine. On this basis the two sub-families may be characterized as follows:

SCOLOPACINæ.-Bill covered with soft skin to the sensitive, vascular, thickened, or laterally expanded tip. Uncovered portion of tibia short, stout. Body and legs rather stout. Neck rather short and stout. Toes generally cleft to the base, (not in Macrorhamphus and Micropalama, \&c.) Gape of mouth very small, not extending beyond the base of culmen.

TOTANIN ж.-Bill covered with soft skin towards the base; the terminal portion hard, horny, and more or less attenuated. Body more slender. Legs and neck slender and lengthened. Toes generally with a basal web. Gape of mouth larger, always extending beyond base of culmen (except in Limosa.)

\section{Sub-family Scolopactne.}

Bill swollen at the end, and covered almost to the tip with a soft skin, the edges only of the rather valted tip horny. The end of the upper bill generally bent a little over the tip of lower. The jaw bone in typical genera finely porous, and perforated by vessels and nerves, imparting a high degree of sensibility to the bill, enabling it to find food in the mud. After death the end of the bill is usually pitted. Legs rather stout; the naked portion of the tibia much abbreviated. The hind toe well developed and generally present; the toes usually without basal membrane, (except in Macrorhamphus, etc.)

Under the head of SCOLOPACIxж, as at present defined, I range two tribes with the following brief diagnosis:

A. Scolopace..-Bill much longer than the head or than the naked leg; the end of the upper jaw thickened and bent over beyond the tip of lower. Roof of mouth not excavated to the tip. A longitudinal furrow along the culmen towards the end. External ear placed beneath or anterior to the eye. Tail banded?

B. Trixge..-Bill shorter than the naked leg, widened 
or rather spoon-shaped at the end, with the edges not bent over. Roof of mouth excavated to the tip. No groove along the eulmen. Eye behrind the ear. Tail without bands?"

Under "Tribe SCOLOPACEæ," he enumerates the genera Philohela, Gallinago, and Macrorhamphus, which are practically the same as our present genera.

Under "Tribe Tringex," he enumerates the genera Tringa, Calidris, Ereunetes, and Mieropalama; and his genus Tringa contains Tringa, Arquatella, Erolia [our Ancylochilus], Schoeniclus [our Pelidna], and Actodromus, which also are very nearly the same as our present genera.

\section{"Sub-family Totaninæ.}

Bill as long as the head, or longer ; the basal portion covered with soft skin; the terminal portion (generally at least half) horny, and more or less attenuated and pointed in ToTANE正. The lateral grooves of bill extending to the horny terminal portion. The gape of mouth extending behind the base of culmen. Toes generally connected by a basal membrane. The tail always with distinct transverse bars in North American species, except in Heteroscelus.

This sub-family appear's to differ from most SCOLOPACIN 2 in the less degree of sensitiveness in the tip of the bill, which is more horny, and not covered by soft skin well supplied with nerves. The toes are almost always connected at the base by a membrane, this being the rule and not the exception, as in Scolopacine.

A. Tarsi covered anteriorly and posteriorly by transverse scutellæ, except in Heteroscelus; finely reticulated laterally. Bill nearly straight, or bent a little upwards.

Totaneж.-Bill nearly straight, about as long as the tarsus, attenuated. Bill not grooved for the terminal fourth. Gape of mouth extending beyond base of culmen. 
Lmose无.-Bill longer than the tarsus, curving slightly upwards towards the end, where it is thickened. Both mandibles grooved for nearly their whole length. Gape of mouth very short, not extending beyond the base of culmen.

B. Tarsi covered anteriorly only by transverse scutellæ, reticulated laterally and behind. Bill curving considerably downwards from near the middle.

Numenie.e.-Lateral grooves not extending beyond the middle. Bill thickened at the tip; longer than the tarsus."

Under "Section [Tribe] Totaneæ," he enumerates the genera Symphemia, Glottis, Gambetta, Rhyacophilus, Heteroscelus, Tringoides, Philomachus, Actiturus, and Tryngites, all substantially the same as they are at present.

Glottis = part of Totanus [Florida Greenshanks].

His "Section [Tribe] Lrmose.e," and "Section [Tribe] Numexiem," are the same as our present representation.

The arrangement as to the order of succession of the above genera are changed somewhat it our present diagnosis.

Genera, Scolopax, The European Woodcock.

Philohela, The American Woodcock.

Gallinago, The True Snipes (2 species).

Macrorhamphus, The Red-breasted Snipe and ally.

Micropalama, The Stilt Sandpiper.

Ereunetes, The Semipalmated Sandpiper and ally.

Actodromas, The True Sandpipers (6 species).

Arguatella, The Purple Sandpiper and 2 allies.

Pelidna, The Dunlins (2 species).

Ancylochilus, The- Curlew Sandpiper.

Tringa, The Knot.

Calidris, The Sanderling.

Eurynorhynchus, The Spoon-billed Sandpiper.

Limosa, The Godwits (4 species).

Symphemia, The Willet.

Totanus, Two species of "Yellow-Legs" and ally.

Rhyacophitus, The Solitary Sandpiper and ally.

Tringoides, The Spotted Sandpiper. 
Machetes, The Ruff.

Bartramia, Bartram's Sandpiper.

Tryngites, The Buff-breasted Sandpiper.

Heteroscelus, The Wandering Tattler.

Numenius, The Curlews (5 species).

The above genera are almost uniformly constant. The old synonymy, and the transferring of species from one genera to another - in past years has but little part in our present advanced ideas about this family.

\section{FAMILY XLII IBIDIDAE THE TRUE IBISES}

Latin and Greek, Ibis, the Ibis.

The Ibises, the Spoonbills, and the Storks, are all intimately related. Their relation is close also to the "Shore Birds" and the Herons and their allies. Writers differ somewhat as to the exact positions of all of these birds, their order of succession amougst themselves is also somewhat open to question. We will follow here an order which, at least, will lead us through the difficulty if it does not present to us the most exact form of relationships between them, and make a different family for each ; more than one writer has given us an example in this direction, and we are bound to follow where others lead when we propose nothing which seems to suit the occasion any better. The True Ibises present the following characteristics : Bill long and slender, curved, compressed, grooved to tip which is blunt not pointed, and with the mandibles meeting quite evenly; tarsus to or a trifle longer than the middle toe and claw, reticulate but scutellate in front; toes barely webbed at base; claws compressed, sharp, and more curved in Eudocimus than in Plegadis; wings rather long, but broad and concaved; tail short; head with bare spaces more or less covering it; bodies small, necks long and thin. The birds look much like immense Rails, yet differing materially from the Herons. They are more or less tropical; and, although found along the Southern borders of North America, perhaps prefer rather the inland river and lake regions to the immediate sea-shore. There are two genera :

Genera, Plegadis, The Glossy Ibis and one ally.

Eudocimus, The White and Scarlet Ibises. 
A variety of synonyms are known for these species, old now, the most important of which are Tantalus, Ibis, Falcinellus, etc.; but Tantalus is better restricted to the Wood Ibis and is, even now, preferred by many for that species.

\section{FAMILY XLIII PLATALEIDAE THE SPOON- BILLS}

Latin platalea, the spoonbill.

The Spoonbill resembles the Ibises in very many respects; but its long, flattened, spoon-shaped bill instantly distinguishes it from anything else in the bird kingdom. The beginning of a gula pouch is also strongly characteristic. Its habitat is much the same as that of the Ibises.

Genus, Ajaja, The Roseate Spoonbill.

The Latin equivalents for Ajaja, still somewhat in use, are Platalea and Platea.

\section{FAMILY XLIV CICONIIDAE THE STORKS}

\section{Latin ciconia, a stork.}

What we call the Stork family differs from the Ibises in that the bill is stouter, is not grooved to tip, tip pointed, nostrils prominent, tarsus long and articulated. Habitat much similar to that of the two preceding families. It has two subfamilies, each of a single genus and a single species.

\section{Sub-family $a$ TANTALIN $2 \quad$ Wood Ibises}

Bill of moderate length with decurved tip. Genus, Tantalus, [or Tantalops,] The Wood Ibis.

Formerly called Ibis.

\section{Sub-family $b$ CICONIIN $\mathbb{E} \quad$ True Storks}

Bill very long, tip recurved.

Genos, Mycteria, The American Jabiru.

Seldom occurs north of Mexico or Texas.

\section{FAMILY XLV ARDEIDAE THE HERONS}

Latin ardea. Greek erodas or erodios, a heron.

The Herons constitute a very easily determined and inter- 
esting group, also a very ancient one. Its members are distributed all over North America, though preferring the warm tropical regions of the continent. They are equally abundant along the seashores and inland about the rivers and ponds. They feed upon fishes and small reptiles, and nest generally in trees. They are familiar objects in nearly every part of North America. Though differing somewhat form the Herons proper, the Bitterns are still true Herons and entitled to a subfamily by themselves. The family has: Bill much longer than the head, very nearly or quite straight, compressed, grooved, and with a sharp-pointed tip; nostril slits near the upper base of the bill; head flattened, loral spaces naked; tarsus naked, reticulated (but scutellate in front), long and slender, toes fitted for wading and with a small, evident basal web - claw of the middle toe like the teeth of a comb beneath; wings and tail much as in the previous families - the feather plumes of the tail are characteristic of many species of this family. Feather plumes often occur also on the hind head and front breast of many species. Neck long and small. The tracts of what are termed "powder-down" are numerous and extensive, and in some species largely developed. The character of these downy tracts needs special study — but the student will not want for characters to define the family, which has two sub-families, The general appearance of shape and plumage alone would almost distinguish them.

\section{Sub-family a ARDEIN 2 True Herons.}

Tail with twelve feathers; the outer toe is not shorter than the inner one.

The True Herons are, generally, more abundant at or near the sea-coast. They build in trees, and their eggs are blue. They generally seek escape by immediate flight when alarmed.

Genera, Ardea, The Great Blue Heron and 2 allies.

Herodias, The Great White Egret.

Garzetta, The Snowy Heron.

Dichromanassa, Peale's Egret.

Hydranassa, The Louisiana Heron. 
Florida, The Little Blue Heron.

Butorides, The Green Heron.

Nyctiardea, The Black-crowned Night Heron.

Nyctherodius, The Yellow-crowned Night Heron.

The changes among the above genera have been something frightful, within very recent years even, and the names Ardea, Egretta, Herodias, have applied successively to nearly every species of the entire family.

Garzetta has been tolerably constant to the SNowy Heron; and Audubonia to the Great White Heron (not the Great White Egret).

\section{Sub-family $b$ BOTAURIN 2 Bitterns}

Tail with only ten feathers; the outer toe is shorter than the iuner one.

The Bitterns are found inland at immense distances from the sea, as well as far North and South on our continent. They build on the ground, and their eggs are brown or white barely tinged. They generally seek escape when alarmed by skulking and remaining quiet until the intruder has gone.

Genera, Botaurus, The American Bittern.

Ardetta, The Least Bittern.

Both the abore species hare appeared under the names of $A r d e a$ and $B \boldsymbol{u}$ tor, but not recently; Ardetta has also been known as Ardeola.

\section{FAMILY XLVI GRUIDAE THE CRANES}

Latin grus, a crane.

The Cranes are usually supposed to occupy a position between the Herons and the Rails. As a family, their size alone would distinguish them. They inhabit the interior of North America. The head is more or less naked, or ornamented with curious appendages peculiar to birds having that curious appearance about the above-named region; the neck and legs are extremely long; bill generally longer than the head, very strong yet slender, straight, and compressed; nostrils large, open, and situated near the centre of the bill ; tarsus with anterior scutellæ, front toes short and partly webbed, and hind toe elerated; head without crest; wings large and broad; tail short, of twelve feathers. There is but a single genus.

Gexus, Grus, (3 species).

The Cranes once passed current as Ardea, but not recently. 


\section{FAMILY XLVII ARAMIDAE THE COURLANS}

Greek arasso, aratto, "a clanging, ringing, rattling noise" implied.

A very noisy bird.

'This curious form is at once known by its peculiarities. Professor Baird thus describes the genus "Aramus" which will do us equally well for a family diagnosis.

"Bill elongated, much compressed, both mandibles decurved at tip. Gonys very long. Bill of equal width nearly from base to tip; nostrils pervious, in the basal fourth of the bill. Head feathered to bill; eyelids only naked. Legs lengthened; tibia half bare; tarsus longer than middle toe; toes without basal membrane; outer lateral rather longer than inner ; middle claws not pectinated. The tarsi are broadly scutellate anteriorly.

The wings are broad and rounded; the tertials equal to the primaries. The first quill is scarcely longer than the tenth, and sub-falcate. The tail is composed of twelve feathers."

Size immense, length 2 feet or over.

The affinity of this bird is curiously shown, by the fact that its South American kindred have received the generic name of Ardea, and both the South and the North American species have been styled Rallus. (It has also been called Notherodius.)

It is a bird of tropical America, and once seen it is not easily forgotten.

Genus, Aramus, The Courlan or Crying-Bird.

\section{FAMILY XLVIII PARRIDAE THE JACANA}

Probably Latin parra, "a bird of ill-omen," from its resemblance to the "lapwing."

Another curious bird, for which a family has been formed, is the Jacanc. This bird also is distinguishable at first sight. It resembles so many different families that its true position may well be a subject for further investigation. It resembles the Rails very closely in many respects. It has not until recently been classed with the North American birds. Its curious bill and face shield ; its wing spurs; its long, naked legs 
and feet; long claws - nearly straight and pointed; determine the species at a glance. Its feet and light weight allow it of walking about on the pads of lillies and of other water plants, so that it looks as if it had the power of walking upon the water. Its body is small. It is really a South American species, but found occasionally along the tropical shores of North America.

Genus, Parra, The Mexican Jaçana.

\section{FAMILY XLIX RALLIDAE THE RAILS GALLINULES AND COOTS}

Probably French râle, "a rattling" noise, "rail, crake," referring to the rattling of their continued notes.

We come now, once again, to a familiar and well-known family representatives of which occur over nearly the entire portion of North America, though principally shore-ward. They are dispersed to some extent throughout the interior of the continent. Nearly every shore-marsh and a great many fresh-water marshes hundreds of miles inland along our seaboard has its Rail fauna. The members of the family are easily known at sight, and a single representative characterizes well the whole group; although its special peculiarities easily separate it into three well marked and stable sub-families. The family characteristics are rather difficult to formulate, in spite of the unmistakable appearance of the birds. Professor Baird's diagnosis of his "Tribe PaLudicolæ" gives us well the features of our family, and is as follows:

"Species living in marshes, with elevated bodies, much compressed laterally; usually with longer necks than most snipe, with moderately long, strong, and stout bills also much compressed aud covered at the tip by a horny investment; the remaining portion membranous, with elongated nasal furrows, and narrow, more or less perforated, nostrils. The lores are feathered uniformly as in the LIMICOL $\mathbb{E}$; the rest of the plumage without the spotting of the snipes. Wings rather short, more rounded than pointed, and when folded do not 
reach beyond the short, soft, and feeble tail ; in fact, seldom to its tail. The outer two or three primaries generally abbreviated. The toes are very long, eleft to the base, thin, and generally with very long claws; the same is the case with the hind toe, which is not only much longer than in the LrmicoLæ, but is generally inserted more nearly on the same level with the anterior ones, touching the ground for most of its extent. The species pick up their fond on the surface, and do not probe the soft mud in search of it."

The Rails are a curious family to study. They are peculiar. Their cry or scream is peculiar. Their shape, general appearance, method of life, food, nesting, and times of appearance and of disappearance in any given region is peculiar. They do not resemble any other family - except casually ; and they might well be made, even, into a distinct SUB-ORDER, so individual are they. The Rails are divided into 3 sub-families:

\section{Sub-family $a$ RALLIN 2 True Rails}

This sub-family is easily determined by having no so-called frontal shield at base of bill. The toes simple and without membranes. The compressed shape of the body is also noted in this sub-family.

Genera, Rallus, The Marsh Rails (5 species).

Porzana, The "Crakes" (5 species).

Crex, The "Corn Crake," [Land Rail].

Rallus and Porzana are, really, both Marsh Rails in distinction from Crex which is eminently a Land Rail. The distinction between the two former is not so evident. Various synonyms have appeared at times for all these species, but they are pretty generally discarded now for those given above. Gallinuta seemed to hold its own for the whole family formerly, as did also Rallus. Creciscus and Coturnicops still occur occasionally. Perdix is old; and Ortygometra, recently discarded, had the support of many good authorities.

\section{Sub-family $b$ GALLINULIN軖 Gallinules}

Frontal shield present; toes with narrow membranous margins in Gallinula, toes simple in Ionornis. The Gallinules do differ from the Raiks in other respects, but it is hard to say 
just how without a careful comparison of the birds. They appear to set higher upon their legs, have rounder bodies, and to be stouter (more robust) everyway.

Genera, Gallinula, The Florida Gallinule. Ionornis, The Purple Gallinule.

Both genera were formerly Gallinula, Ionornis was also Porphyrio.

\section{Sub-family $c$ FULICIN $\$$ Coots}

Frontal shield present, and toes with scalloped membranes. The body has none of that compressed shape so noticeable in $a$ and barely seen in $b$, but is rather the reverse as to pressure (depressed rather than compressed). This is an inland bird, and common all over the continent. It has a single genus and a single species.

Genos, Fulica, The Coot or Mud Hen.

\section{FAMILY L PHOENICOPTERIDAE THE FLAMINGOES}

Greek phoinikopteros (Latin similar), red-winged.

The extraordinary bird for which this family is formulated has been placed by some writers with the Storks, the Cranes, etc., and by others with the Geese and Ducks. By placing it between the two, yet not making it a subordinate portion of either, we overcome the difficulty as much as it seems to us to le possible. The Flamingo is a bird that could not be mistaken for any other known species. Its immensely long neck and legs, its curiously formed bill, and its size, place it at once. The adult plumage is scarlet with black ends to the wings. There are but few species and they occur in the tropical portions of the globe. Our species inhabit the Southern portion of North America, and build immense mud piles for nests - a curious study in themselves. We have but one genus and a single species.

Gexus, Phomicopterus, The American Flamingo. 


\section{FAMILY II ANATIDAE THE SWANS GEESE AND DUCKS}

Latin anatinus, "pertaining to a duck," duck-like.

It may seem strange, to one not well acquainted with the species, that all of our North American Swans, Geese, and Ducks should be classed together in a single family. A little careful study, however, will show how constant certain characters are throughout all these birds, and that the deviation from the typical structure could not well command a higher recognition than that of sub-family. Accordingly we separate the family into several groups or sub-families, and find that they fit in with a nicety that shows how well they merit such relative positions. Wherever one goes upon our continent, north, south, east, or west, - along the seacoast or in the interior - they find members of this family common and even abundant. Again, the number of species are so comparatively few that one would scarcely look for very extensive special faunas for special localities; this would render the great majority of these species of almost universal distribution - at least throughout North America. The few of specially localized occurrence are, usually, the rarer forms only.

This family, as a family, is somewhat difficult of definition. Its main features are: Bill with series of plates (lamellæ) extending around the edges of both mandibles and fitting into each other, when the bill is closed, like teeth - general shape of bill, high and feathered (more or less) laterally at the base, tapering to a flattened and wide thin tip - tough, strong, and yet of somewhat elastic material, the end terminating with a horny shield or NAIL of various sizes and shapes in the different species; nostrils variously shaped and placed in the different sub-families and genera ; the short legs are feathered usually quite to the tarsus, which is variously scutellate or reticulated, toes fully webbed, sometimes somewhat incised, and hind toe simple or barely membranous; wings moderate or long, pointed, narrow, strong, and elastic ; tail short, usually rounded; body compressed, neck long, head large - comparatively. Their anatomical characters are of special interest, 
and should be studied separately. Their digestive organs are also worthy of special investigation and comparison.

Professor Baird gives the following table which will greatly aid in the study of the higher divisions of the family :

"A.-The teeth of the bill directed downwards, the lamellæ composing one series only on the edge of the upper jaw. The rami of the lower jaw separated. Bill broad; depressed at the end.

A.- Tarsi reticulated, covered anteriorly with small hexagonal plates, gradually becoming smaller and rhomboidal laterally. Hind toe without free lobe.

Cygnine.-Neck very long. Bill high at the base; longer than the head; of equal width to the rounded tip, with its narrow nail. Soft skin of bill generally extending to the eye. Tarsi shorter than the middle toe without claw.

AxSERINe.-Neck rather long. Bill high at base; as long as or shorter than the head, narrowing to the tip, which is chiefly formed by the large nail. Region in front of the eye feathered. Tarsi longer than middle toe without claw.

B.-Legs with transverse plates or scutellæ anteriorly, these becoming much smaller and more hexagonal laterally and behind. Tarsi generally shorter than middle toe without claw.

Aratrix.-Hind toe without a broad membranous lobe attached. Tarsi not longer than the middle toe; feet moderate.

Fuligulixæ.-Hind toe with a broad membranous lobe depending from its under surface. Feet large. Nail of bill superior, gently decurved. Tail rather soft; the coverts well developed.

Erismaterix.e.-Toes and feet as in the last. Nail of bill abruptly bent back from tip of bill, showing but little on upper surface of the latter. Tail feathers 
rigid, spinous, and almost entirely exposed; the coverts much abbreviated.

B.-Bill high at the base, much compressed. The lamellæ directed backwards as serrations. The upper jaw with two series of teeth on each side; the lower with one which fits between the others. The nail of the bill compressed, much curved, forming the tip of the bill. Edges of bill nearly parallel. Legs with transverse plates anteriorly.

Mergrn Æ.-Characters as above."

Most writers do not make the Erismaturinde a separate sub-family from the Fuligulix., otherwise the above table answers perfectly for our present classification. We shall unite the two into one sub-family, and call it the FuLIGULIN ж. The family divides itself naturally into the following sub-families :

\section{Sub-family $a$ CYGNIN 7 Swans}

The difference between the Swans and the Geese is easily recognizable. The size of the former, alone, would separate them; add to this the naked loral spaces and there will be very little difficulty in telling them apart. Swans are still rare in North America, and our species are now reduced to four well-marked and constant forms. There is but a single genus, though writers differ in names; some calling it Cygmus and some Olor. Whichever form we admit, we must recognize the other as an equivalent sYNONYM and not a sub-genus. Swans appear to resort more to inland and fresh waters than to the sea coasts, and to the extremes of the continent in arctic or sub-arctic rather than ordinary temperate regions.

Gents, Cygnus or Olor, (4 species).

\section{Sub-family $b$ ANSERIN $\$$ Geese}

The Geese are much better known throughout North America than the Swans. They inhabit all portions of the continent - inland and seaward, north, south, east, and west. The 
species are not many, yet they congregate in immense numbers in favorable and favorite localities. Though, like the Ducks, they have the feathered loral spaces they are easily distinguished by the reticulations of the tarsus - neither are the legs placed so far backwards which gives them a firmer waddle when they walk. The habits, in general, of Geese seem to be more periodic and regular than of the Ducks. The habits of the different species are not so well known as they should be, and here is a fine field for the working ornithologist. The different genera are well marked, and all of our species now pretty fairly characterized, notwithstanding their former confused state.

Genera, Chen, The Snow Geese (4 species).

Anser, The White-fronted Geese (2 species).

Philacte, The Emperor Goose.

Bernicla, The Canada Geese or Brants (7 species).

Dendrocycna [or Dendrocygna] The Tree Ducks (2 species).

We shall not enter upon the old synonymy of this sub-family, yet a few points may be necessary. Anser was often used for both ANSER and CHEN; Anser and Bernicla were used interchangeably for BERNICLA; and Dendronessa for DENDRocrcia : this latter was formerly classed with the Ducks as Anas.

\section{Sub-family $c$ ANATIN $\$$ River Ducks}

The majority of this sub-family are easily recognized It is not so easy to draw the line between them and some of the duck-like geese and the Sea Ducks ; yet the arbitrary distinguishing characters - for such they are in reality - are near enough to give us a fairly accurate diagnosis. The small size, the short neck [and legs], and the flattened, rather than rounded or compressed, shape of the bill uniting with the feathered loral spaces and scutellate, rather than reticulate, tarsus and simple hind toe (hallux), will greatly assist in the separation from the other sub-families. It were less difficult to define the difference between the Cieese and River Ducks, than that between the latter and the Sea Ducks. The River Ducks are, emivently, RIVER Ducks. They frequent rivers, pouds, lakes, and inland waters generally. They seldom oc- 
cur seaward to any very great extent, and prefer the shallow waters of marshy or overflowed lands where they can procure a more delicate assortment of fine fresh plant and other food, suited to their taste, than their neighbors the Sea Ducks, who secure their food almost exclusively by diving for it. The flight of River Ducks is generally high, light, and rapid; while it is, on the contrary, low and heavy - though more often long-sustained than remarkably rapid - with the Sea Ducks. River Ducks are, therefore, very different from Sea Ducks. They might well be styled the more refined and aristocratic birds of the family. The genera are :

Genera, Anas, The Mallard or Black Ducks (3 species).

Dafila, The Pintail Duck.

Chaulelasmus, The Gadwall Duck.

Mareca, The Widgeons (2 species).

Querquedula, The Blue-winged Teal and ally.

Nettion, The Green-winged Teal and ally.

Spatula, The Shoveller Duck.

Aix, The Wood Duck.

Mallard hybrids (with other ducks) are not rare, some of these offspring prove fertile, contrary to the generally accepted rule.

The above generic names seem to have come safely out of the former synonymic confusion. A few suggestions are still of interest. Anas formerly stood for almost anything and everything in the Duck family. The student will avoid a great deal of confusion by paying little attention to former uses of Nettion and Querquedula other than as given above. Various names ending in nessa, such as Dendronessa, Lampronessa, etc., have been used for the Woop Duck; this will only show its formerly supposed kinship with the "Tree" Ducks (our present Goose form) Dendrocygna.

\section{Sub-family $d$ FULIGULIN $\$$ Sea Ducks}

The Sea Ducks are eminently diving ducks. While the River Ducks do not seem to glide into the Sea Ducks, yet the Sea Ducks do seem to glide into the River Ducks, and then to glide out again as serenely as if they had never seemed to approach them. We see, in this family especially, the absurdity of what I call the LINEAR THEORY, or trying to arrange each species according to its likeness to the one before and the one following it. Sea Ducks love the Sea; and are generally found 
singly or in large flocks far from land (one to three miles), where they sport in the water and feed at their pleasure at regular intervals of the day and in the evening. They often go about in immense flocks, feed together, and even breed in colonies. They fly long distances, but usually their flight is heavy. Their habits vary with the species throughout the sub-family: Some prefer the sea far out, some in shore, some the bays and inland parts of the estuaries, and a few are abundant in wholly inland and even fresh waters. The lobate form of the hind toe at once distinguishes the group, while both feet and bill are usually larger and stronger than in the River Ducks. The strong and compact "build" and size of this subfamily are in striking contrast to the light, swift "build" of the River Ducks.

Genera, Fulix, The Blackhead or Scaup Ducks (3 allied species).

Ethyia, The Canvas-back and Red-head Duck.

Clangula, The Golden-eyed Ducks (3 allied species).

Harelda, The Long-tailed Duck.

Histrionicus, The Harlequin Duck.

Camptoloemus, The Labrador Duck.

Somateria, The Eider Ducks (6 species).

Edemia, The Scoter or Surf Ducks (4 or 5 species).

Erismatura, The Ruddy Duck.

Nomonyx, The St. Domingo Duck.

Polysticta and Lampronetta seem to be fairly scB-GENERA of Somateria proper; the former being applied to Steller's Eider and the latter to the Spectacled Eider.

Melanetta for two varieties of Velvet Scoter, and Pelionetta for two varieties of true SurF Ducks (species $P$. perspicillata and $P$. Trowbridgii), stand for true SUB-GENERA.

Erismatura seems tolerably constant. [There may be two species]. It has been made a separate SUB-FAMLY, and may be still entitled to such consideration.

Ethyia is not a sub-genera of Fulix, as some would seem to lead us to suppose (also spelled Aythya), and Fuligula seems to be an old name for most everything, [as was also Anas,] in the duck family. The CanvasBACK has sometimes received the name of Aristonetta, as "Aristonetta vallisneria, Baird," in Professor Baird's "Birds of North America," (Ninth volume of the Pacific Railroad Report, p. 794). This name is a genuine relic - a curiosity. On the previous page (793) Professor Baird says, "should it be considered expedient [for reasons stated] to establish 
for the Canvas-back a new genus, the name of Aristonetta would be very appropriate, on account of the great superiority of its flesh as an article of food." It is significant, however, that the Professor himself does not use the name (save as a synonym perhaps), but uses Aythya.

Clangula and Bucephala appear to be used about equally for the GoLDEN EYE, though preference seems to favor the former, at present. [Histrionicus was formerly a ClangULA, - but did not remain so long].

The Eider Ducks seem to be curiously synonymed. Somateria is really the standby for all of them: yet the Steller's Eider has received, respectively, the names of Eniconetta, [Heniconetta?], and Polysticta, as well as Somateria; The Spectacled Eider, the names of Lampronetta and Arctonetta, besides Somateria; four others have been classed as Somateria proper - yet even here we are not allowed to rest in peace, as the name of Erionetta is fnrther suggested for the King Eider. All of these names appear to have been used as of GENERIC RANK formerly. The hosts of old synonyms, besides these, now of no sort of practical use save as a matter of reference merely, is legion.

The SurF Ducks have been styled both Edemia and Oidemia; the synonym Melanetta is distinct from Melanitta used by BoIE for perspicillata.

\section{Sub-family $e$ MERGIN 㞋 Mergansers}

The Mergansers are evidently distinct from either the Sea Ducks or the River Ducks; but whether they combine the characteristics of the former with the habits of the latter, or VICE VERSA, is not at first so apparent. A careful examination of these birds leads us to believe that they are more Sea Ducks with the habits of inland Water Ducks. As a subfamily they are at once distinguished from their neighbors by the shape and character of the bill; the saw-like rows of sharp-pointed teeth at once proclaiming the position of the bird. They are carnivorous ducks. They live upon fish, it is true; yet they are rather scavengers than birds refined in their tastes and food. They were formerly classed with the Sea Ducks. The Mergansers, with their toothed bills, bear a not distant resemblance to recently discovered toothed fossil forms. There is but a single genus.

Gends, Mergus, The Mergansers (3 species).

Sub-genera. Lophodytes is a sub-genera of Mergus, and is used for the Hooded Merganser - it is often accorded generic rank even.

Merganser was an old-fashioned generic name, but it is seldom met with in modern writers. 


\section{FAMILY LII SULIDAE THE GANNETS}

The derivation of this word is very questionable. Latin sol, Welch sûl,?

This is a small family and is not difficult to distinguish from all others. Though at a distance it might easily be mistaker by a novice for a true Goose, near to it bears no sort of resemblance. They are large, cumbersome-lonking bodies with very little that is graceful or agile about them or their movements. They are, on the contrary, fine swimmers; and are, to a very great extent, gregarious - living and breeding in large numbers in special and favorite localities. Size large length from 30 to 40 inches and extent of wings 50 to 70 (the average of both species); bill long, as long as or longer than the head, straight and slightly compressed, rery stout at base and tapering to awl-shaped point which is a trifle decurved; nostrils and groove very small; gular sac present, but this also very small; tarsus short and stout, toes long and slended and fully webbed; wings long, pointed, and rather clumsy; tail short and cuneiform.

Genus, Sula, 4 species.

Sub-genera, Sula, The Common Gannet and 1 ally.

Dysporus. The Booby Gannet and 1 ally.

The Gannets are still all classed under Sula by many writers; they formerly received the generic equivalent of Pelecanus. Though Dysporus was also used at one time for the Common Gaxnet, it was discontinued when it was found that that bird was really a typical Sula.

\section{FAMILY LIII PELECANIDAE THE PELICANS}

Latin pelecanus, Greek pelekinos, a pelican.

The Pelicans require very little description for their determination and identification. Their peculiar shape and size are familiar to us, at least through pictures, from our childhood. The enormous development of the gula sac, a membranous attachment to the lower mandible, alone would fix the species - and the family - indelibly in our minds. In size they vary from four and a half to five feet in length, and from six and a half to eight and a half in extent. The bill is very long, and rery peculiar in shape and size - as to both upper 
and under mandible; nostrils very insignificant; wings very long; tail very short; tarsus short, stout, and reticulated, toes long and fully webbed. In general, excepting the bill and its accompanying sac, they greatly resemble immense and sluggish Gannets. The Pelicans are largely gregarious, preferring tropical and sub-tropical regions; yet there are few species known to science.

Genus, Pelecanus. 3 species.

Professor Baird appears to have given us two suB-Genera: Cyrtopelicanus (White Pelican) and Onocrotalus (Brown Pelican). At least, if considering only the American species they might rank as such. In a classification of Universal ornithology they might take GENERIC rank.

FAMILY LIV PHALACROCORACIDAE CORMORANTS

Latin phalacro | corax (Greek similar) a sea-raven, a cormorant.

Unlike the Pelicans the Cormorcents are not so easily identified, at first sight, to a novice, as might be supposed ; and yet when once known they are easily remembered. They average about the size of the Gannets, yet some are much smaller and others much larger. The general color of the plumage is more or less metallic and black. Their general characteristics are rather difficult of easy definition. A single careful glance at a specimen will serve to $f(x$ it in the mind better than a fuller and more careful diagnosis of the family or than any mere description. I shall quote Professor Baird's description of the family characteristics :

"Bill rather moderate, culmen concave, tip much hooked and acute; nostrils not perceptible; wings moderate and pointed; tail rather short and rounded ; tarsi short ; toes long and all joined by full webs; gular sac capable of considerable expansion."

This, in general, will give a very fair idea of the Cormorants, yet is far from satisfactory. The long neck and the shape of the head and bill are marked peculiarities. The legs also are situated so far in the rear of the body as to give these 
birds the same general appearance, when on land and in an upright posture, as in the auks and puffins, with which they often associate. They are fish feeders, expert divers, gregarious, and found all over the world.

Gends, Phatacrocorax, (10 to 11 species).

Graculus is a GenerIC synonym, and Prof. Baird gives us what appears to be three sub-Genera: Phalacrocorax, Graculus, and Trile. The old generic appellations of Pelecanus and Carbo are now seldom heard of. Carbo alone is still occasionally adhered to for its simplicity.

\section{FAMILY LV PLOTIDAE THE DARTERS}

Greek plotos, "a powerful swimmer.

A more extraordiny bird than the Daiter, or Snake Bird as it is frequently called, could hardly be imagined. It is one of Nature's curiosities. It is also known as the Anhinga or II ater Turkey, is a native of tropical waters, and has but few representatives in any country. The common American species is a resideut along the Gulf States, and a familiar object in places where it abounds. At a distance, it might be mistaken for a member of the Goose family but for its long, slender, straight yet pointed bill; and for a large Heron or Egret, but for its short legs which are situated so far back upon its body. It has a slight pelican-like pouch which is naked, and very small nostrils. The wings are long and pointed; and the tail, of moderate length, is broad and stiffened and composed of twelve feathers. The Durter might resemble a longnecked Cormorant, but it is of a more slight, neat, and trim appearance. They are swamp-dwellers, feeding upon reptiles and fishes for which they dive and swim with remarkable dexterity. The habit of swimming with only the head above the water has procured for it the name of surkic Bird, as it then greatly resembles that reptile.

Gexus, Plotus, The Anhinga or Snake Bird.

\section{FAMILY LVI TACHYPETIDAE THE FRI- GATE BIRD}

Greek tachupetes, swift-flying.

This is still another bird that could not, by auy possibility, 
be mistaken for any other species. The characterization of the Genus Tachypetes, by Vieillot, as given by Professor Baird, is so apt that we quote it entire :

"Bill long, broad at the base, the culmen concave, the unguis much hooked and very acute, the sides grooved and compressed ; nostrils basal, linear, and hardly visible ; wings very long and pointed, first two primaries longest; tail lengthened and deeply forked; tarsi very short, strong, compressed, and feathered for half their length; toes long and all united by webs; claws curved and rather small; gular sac extending nearly to the end of the lower mandible aud admitting of considerable expansion."

Thus, in a word, the general appearance is of an immense kite-like bird with long, narrow, pointed wings; long, forked tail ; rather long bill and neck ; short legs; and a lean, attenuated body. They are tropical birds and lonely wanderers about the ocean, far from land and high in air. 'Their power of wing - of flight - is scarcely surpassed by any other bird known. They breed, as do the Tropic Birds, in large numbers together, on or near the ground along the coast. They are poor swimmers and divers and walk badly, but wing the strongest tempests far to sea and high in air. It might well be called the Water Eagle or Robber. There is one species.

Genus, Tachypetes, The Frigate Pelican, The Man-of-War Bird.

Has been classed as Pelecanus, [also Fregata and Attagen].

\section{FAMILY LVII PHAETONIDAE THE TROPIC BIRD}

Greek phethon, - See the legend of Phaëtbon in Mythology.

This is the last of these "Freaks of Nature," as one might almost call them, for which the Order STEGANOPODEs is so noted. It is associated with the $M a n-o f-W^{\top} a r$ Bird, and very much resembles it in many particulars. Their habits are much the same, as are also their habitats : yet the one represents the Lion Bird-King and the other the Dove-Lamb. The one the fierce, untamed, powerful-and skillful-winged scorner and 
lover of the tempest; the other the calm, gentle, - yet no less master of the air - Dove-like Commander of the Sky, who views all below him with unmoved eye and unruffled breast, yet conscious of a power that guides him even in the fury of the storm. Thus the two birds picture themselves to my mind. The description of the Genus РнÆтох, of Linnæus, as given by Professor Baird, is :

"Bill about the length of the head, strong, broad at the base, compressed, the culmen curved to the tip, which is pointed; nostrils lateral, basal, and pervious, situated in a short groove near the ridge; wings long and pointed, the first primary longest; tail graduated, the two middle feathers extremely lengthened and narrow; tarsi short and stout; toes rather long, all counected together by full webs; claws small, curved and rather acute."

At a little distance the Tropic Bird does not look very unlike an immense Dove or Pigeon with two immensely long, streaming tail-feathers. A very little stretch of the imagination would picture it as an object of veneration and worship throughout the splendid dominions, on festal occasions, of the Montezuman dynasty - this Gull-LIKE SuN Bird.

Genus, Phathon or Phaton, The Tropie Bird (2 species).

(Formerly called Lepturus.)

\section{FAMILY LVIII LARIDAE THE GULLS AND TERNS}

Latin larus, Greek laros, "a ravenous sea-bird the Mew."

This is the last large family with which we have to deal; it is a large family, yet the singular regularity or conformity of structure which runs through all of its members renders it an exceedingly easy one of which to treat. With the exception of one or two species, the Gulls and Terns can usually be told at sight. They have, generally speaking, long and powerful though rather slender wings, and are capable of long-continned flight and surprising agility. Their bodies are long and slender rather than short and robust. There is very little 
difference in the general gull-like appearance of the different members of the different sub-families, though some of them display more agility of wing than others. The larger birds have an apparently slower and steadier motion while on the wing than the smaller species, yet this may not be strictly true - their larger size may only make it seem true. All the members of the family are remarkable for their habit of diving, from high in the air, for their prey, and will often remain entirely submerged for several seconds at a time; yet, as a rule, they are not diving birds. Their bodies are extremely bouyant while they rest upon the water, and they swim with ease, grace, and facility. They are more or less gregarious, often flying together in flocks of many hundreds or even thousands. All their motions are full of grace, and even their walk has a sort of daintiness about it that makes it appear not altogether awkward. Although the sea and seacoast are their places of greatest resort they are not confined there altogether, and many species follow up the larger streams and even occur far inland about lakes and ponds and other large bodies of water. They are distinguished from their near allies the Petrels by the absence of the tubular nostrils, for which the former are noted. There is no gular sac. The bill is long and dart like. The toes well webbed; hind toe short, elevated, and free. The general color white or pearl-gray (bluish). In general appearance not unlike a Sea Dove.

Professor Baird gives the following brief diagnosis of the four Sub-families of this FAMILY :

"Lestridin «.-Basal half of upper jaw with a horny covering, distinct from the tip, and under which the nostrils open considerably beyond the middle of the bill. Bill abruptly and much decurved at the tip. Tail cuneate. Body full, stout.

LARINA.-Covering of the bill continuous. Anterior extremity of nostrils generally reaching to the middle of the bill. Culmen generally decurved towards the tip. Body robust. Tail generally even. 
STERninж.-Covering of bill continuous. Nostrils opening in the basal third of the bill. Culmen gently curved to the tip of the lengthened and attenuated bill. Body rather slender. Wing lengthened. Tail usually deeply forked.

RHYxchopixæ-Bill excessively compressed, like the blade of a knife. Lower jaw much longer than the upper ; the point obtuse. Body slender ; tail forked."

\section{Sub-family a LESTRIDIN A}

Skua or Jager Gull

The shun or Jager Gulls are most extraordinary birds. At first sight they resembl the smaller species of Hawks; a second view of them makes them appear dark-colored Terns. The immense cered mandibles strengthen the former idea, and their graceful, powerful, and wonderful agility of wing and power of flight the latter. When riewed near to they apparently turn out to be neither, and the young student cries out excitedly, "What can it be?' The stimas have been the subject of a great deal of study and speculation. They have been variously classed by different writers and have received a large number of generic appellations, but have now been reduced to a single well-established genus. They are arctic-temperate rather than tropical-temperate species. The ciexts is thus characterized in Professor Baird's Report (p. 8.38): "Stercorarius, Bristox. Bill rather strong; culmen straight and covered at the base with a smooth cere, the end curved. Nostrils linear and more open anteriorly. Wings pointed; first quill longest. Tail of moderate length; the two middle feathers elongated. Tarsi strong, and curved with prominent scales; claws sharp and much curved. Feet fully webbed; hind toe short and but little elevated."

Gevus, Stercorarius, 4 species.

There are, properly speaking. no sCB-GENera. unless the name Megalestris for the SKUA GuLL (in distinction from the other three which are true Jagers) be such. The names Lestris, Catarracta, and Buphagus are only srvoxims for Stercorarius. 


\section{Sub-family $b$ LARIN $\mathbb{2} \quad$ True Gulls}

The True Gulls are too well known to need any extended introduction. Though some of the species are giants and others dwarfs, they all possess a similarity of appearance and of habit which at once characterizes them and binds them together. They have little of the agile flash-like flight of the Skua's, and still less of the methodical scissor-like flight of the Terns. They are, rather, bold, powerful, slow-moving brigands, whose wild screaches send terror into the hearts of all smaller species, whom they seem to laugh at as if they considered them much inferior beings. The sexes are alike as to plumage in the Gulls as well as in the Terns. The young are of different degrees of brownish or greyish-brown, and distinctly noticeable even among the flying birds. They are two to three years in maturing, the plumage from very dark brown becoming lighter and lighter at each succeeding moult. A full and thorough study of the Gulls has never been made. We shall not attempt to characterize it further.

Genera, Larus, The Gulls Proper (14 or 15 species).

Chrö̈cocephalus, The Laughing and Rosy Gulls (3 species).

Pagophila, The Ivory Gull.

Rissa, The Kittiwakes (3 species).

Rhodostethia, Ross's Gull.

Xema, Sabine's Gull.

Creagrus, The Swallow-tailed Gull.

Some writers do not recognize Chrö̈cocephalus as differing from Larusunless, perhaps, as a SUB-GENUs; and, though the distinction is more nearly generic, yet really Rhodostethia is certainly a sUB-GENUs of Rissa.

In the same way, if not really a distinct genus, Creagrus is a sob-GENus of Xema.

The synonymy of this sub-family had better not be attempted by the young student, as he will find a strange tangle of Larus, Laroides, Leucus, Atricilla, etc., and other vexing suggestions.

\section{Sub-family $c$ STERININ Terns}

The difference between the True Gulls and the Terns is not technically so great as would at first seem. The general appearance, however, is much more evident. The long, pointed wing, the strongly marked bend of the wing, and the length- 
ened body, are all characteristics of the Terns. They secure their food - usually fish - by darting upon it, from high in air, with the velocity and the true aim of an arrow from the bow of an expert archer. Most Terns have a forked tail, so that one can generally tell them, even while yet in the air, from Gulls. They often occur a short distance inland, but seldom stray far from the seacoast or its immediate vicinity. Teins are social birds and fond of each others company; throw a dead tern even up high into the air and, if there be any living terns near, even if not in sight at the time, numbers will swoop down upon you in a moment. In general: Bill usually hard, horny, even at the point, and sharp tipped; the nostrils are always prominent and opening from one side of the mandible to the other and are oblong slits - more or less basal. Toes usually long compared to the short and weak tarsus; webs not quite full, and concave rather than straight edged. Eren the roung student, after a moment's examination, will hardly mistake the Terns for the Gulls.

Genera, Sterna, The True Terns (14 species).

Hydrochelidon, The Black Tern and ally.

Anous, The Noddy Tern.

Sub-GenerA, Gelochelidon for The Gull-billed Tern; Thalasseus for the Caspian, Cajenne, Elegant, and Sandwich Terns; Sterna [proper] for the Wilson's, Forster's, Arctic, Roseate, Trudeau's, Least, Aleutian, Sooty and Bridled Terns. The Sooty Tern is sometimes named Haliplana.

The srNonYus are hardly worth mentioning, being almost invariably Sterna, (Sternula [little Sterna] for The Least Tern,) and Thallasseus.

\section{Sub-family d RHYNCHOPIN \& Skimmers}

The bill of this bird alone distinguishes it from anything else in the bird kingdom. It is like a long, blunt pair of shears, with part of the top (the upper mandible) broken off part way from the tip which is then filed to a rounded point as it lays upon its fellow. Otherwise it is a true Tern. Only three species are, I believe, knotrn to science; one alone inhabiting North America,

Gexus, Rhynchops, The Black Skimmer. 


\section{FAMILY LIX PROCELLARIDAE THE PETRELS}

Latin procella, connected with a storm, something stormy, a storm bird.

The Petrels, at least the True Petrels, may best be compared to the familiar common Dove or Pigeon: They are, in fact, Sea Pigeons to all appearances when viewed from a little distance. Near to, the technical difference is much greater. Taken as a family, they vary greatly as to size. Professor Baird thus characterizes the family as a whole:

"Bill much or less lengthened, compressed, and deeply grooved, appearing to be formed of several distinct parts; the tip is strong, much hooked, and acute; the nostrils open from distinct tubes, either single or double, and are situated at the base of the upper mandible."

While the above is, probably, as accurate as the circumstances will permit, we must look at the two sub-families, which differ very materially from each other, for a better knowledge of the group. The hind toe is very small, and more or less elevated, even sometimes altogether wanting at least for all practical purposes. They are strong swimmers, and their flight is easy, not ungraceful, and capable of long continuance. They pick their food up from the top of the water, and are not divers. Their long wings and short tails, together with their curious habits of flying close to the water - probably most of the time - render them conspicuous objects at sea. We know so little of the general habits of this family that anything really new about them would be a boon to science; they are worthy of a very special and careful study. We have two sub-families:

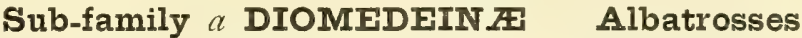

The technical difference between the Albatrosses and the True Petrels is very evident, the shape and position of the nostrils alone would distinguish them regardless of size. As a matter of fact, the Albatrosses are immense creatures: the Giant Fulmer alone approaching it partially as to size. The 
nostrils are entirely separate and disconnected, and situate one on either side the mandible. They are found usually far from land, and would seem to be sea-birds in the truest sense of the word, seldom approaching land save for breeding purposes. Two genera are known to North America.

Genera, Diomedea, 2 species.

Phobetria, 1 species.

Phobetria seems to be a proper genus, rather than a sub-genus, though often occurring under the generic name of Diomedea. I know of no synonyms: [Unless Thalassarche, which is a sort of sub-genus of Diomedea, be one. It is used by Professor Baird as is the name Phobastia-both are used, however, rather as expressive of GENERIC peculiarities than in a sub-generic sense].

\section{Sub-family $b$ PROCELLARIN $\mathbb{\text { F }}$ Petrels}

The True Petrels are known at once by the curious shape of the nostrils, which have the appearance of a very short double-barreled gun saddled to the base of the upper mandible. The general features of the Petrels are best studied, as are many other of the bird groups, by means of a "typical" specimen. Nearly all of the members of the group conform, with slight variations in each genus, to this typical specimen - and almost any one of the SCB-ORDER will serve as typical. Many families do not require this mode of study, a few do. The shrupes of the nostrils, of the wings and tail as modified by the number of their feathers and the forked, even, or wedge-like appearance of the latter, size of both wings and tail, and even the coloration of the rarious parts, all vary in the different species and genera.

Generi, Ossifraga, The Giant Fulmar.

Fulmarus, The True Fulmar (3 species).

Priocella, The Slender-billed Fulmar.

Priofinus, The Black-tailed Shearwater.

Puffinus, The True Shearwaters (10 species).

Estrelata, The Black-capped Petrel and ally.

Daption, The Cape Pigeon.

Halocyptena, The Least Petrel.

Procellaria, The Stormy Petrel.

Oceanites, Wilson's Petrel.

Cymochorea, Leach's Petrel and 2 allies.

Oceanodroma, The Forked-tailed Petrel (2 species).

Fregetta, The White-bellied Petrel. 
The synonymy of the Petrels, all things considered, is one apparently of strange inconsistency, and I would not advise the young student to bother much over it. Professor Baird added Daption and Fregette to the family, and he gives a $\mathrm{SL}^{\circ} \mathrm{B}-$ GENUs for nearly every individual species besides. The names Procellaria, Fulmarus, Thalassidromas, and Puffinus, were used by old writers as synonyus, generally for the whole sub-family and in their present restricted sense.

\section{FAMILY LX COLYMBIDAE THE LOONS}

Greek kolumbos, Latin colymbus, "a kind of water fowl."

The Loons might at first be somewhat puzzling to a novice, were he not familiar with both the name and the general form from his childhood's picture books. When flying high in the air, they are easily mistaken for the Canada Goose unless one is quite familiar with the appearance of both birds. It is on the water that the Loon is in his native element. They swim with ease and grace; dive at the flash of the gun ; and swim long distances under the water, apparently without very great exertion. They only take wing when compelled to, preferring to escape their pursuers by diving. They are easily distinguishable when examined closely: The long, stout, eompressed, straight, and sharp-tipped bill; long, narrow, and lobed nostrils; strong and long-pointed wings; short, thick tail ; legs situated very far back making it difficult for them to walk on land; toes all present, webbed; these features tell the Loons at once. They are usually spotted black and white above, and pure white beneath. Their curiously harsh and fiendish cry has struck terror into the heart of many a camperout quietly taking his first outing by the side of some cool inland lake or stream. There is but a single genus.

Genus, Colymbus, 5 species.

The old-time Eudytes or Eudites are not now in use except for references.

\section{FAMILY LXI PODICIPIDAE THE GREBES}

Latin podex buttox, and pes foot; buttox-footed.

The Grebes, though strongly resembling the Loons in very 
many respects, are yet easily told from them at a glance. They were formerly classed as a sub-family of the divers, although now made a distinct family. Their habits are, in the main, almost identical. The technical difference between the two families is easily seen by the appearance of the feet-webs. The feet of the Loons being what are known as palmate, that is the membrane connecting them is smooth and entire (incised, cut into, or not); while those of the Grebes are lobate, scalloped or lobed, and running down each side of each toe nearly or quite to its base. Aside from this they are usually much smaller; the bill blunter; the wings more rudimentary; the body feathers greasy or oily to the touch; and the plumage not black and white spotted above and pure white beneath, but more or less brownish dusky all over.

Genera, Achmophorus, 2 species.

Podiceps, The American Red-necked Grebe.

Dytes, 3 species.

Tachybaptes, St. Domingo Grebe.

Podilymbus, The Pied-billed Grebe.

Formerly Podiceps was used for all the Grebes; later Podilymbus became a stable genera. Colymbus was also used for nearly if not quite all species of both Grebes and Loons. Other synonyms, now somewhat out of date, need not be mentioned here. The Podiceps cristatus, or Crested Grebe, so frequently cited by former writers, is not now recognized even as being a North American species.

\section{FAMILY LXII ALCIDAE THE AUKS AND PUFFINS}

Derivation uncertain, perhaps like alcedo or halcion, pertaining to the sea.

The Aulix and the Puftin: constitute the last family of which we treat, and they are, without doubt, one of the most interesting. To study them carefully and fully one must visit them in their home, the Arctic regions of both coasts of both continents; for there they make their home. The Auks are the lowest specimens of the bird kingdom the Penguins excepted, and are placed naturally at the end of the bird kingdom ; why writers should be at such pains to reverse this apparently natrral order and put the lowest water birds FIRst, thereby ren- 
dering it necessary to put in a reverse order every specimen and every group in the sub-kingdom, in order to conform to what I call the LINEAR THEORY, we confess we are at a loss to imagine. The Auks are the least developed of the birds. Their legs are situated so far back that they walk and even stand with difficulty; their wings are rudimentary; and their habits primitive. They seem to have little vitality save that of mere existence. They lay generally a single egg - seldom more, and often leave the sun to hatch that. They are eminently social, often assembling together in regular colonies; and, though stragglers are sometimes found a great way from home, they seldom stray far away from the main body of their associates.

As a family they are easily told from their neigbbors in the same ORDER by having but three toes to their feet, all fully webbed. The tail is short and of few feathers. The bill is variable in shape and often subject to seasonable, periodical, or sexual ehanges. They are confined to the sea-board, though severe gales often blow them many miles inland. When once on wing they fly well, but prefer the water where they are perfectly at home, swimming and diving with great facility. Their notes are harsh and few. There are two well-defined sub-families, though they are scarcely distinguishable so very closely do they run into each other. Many authors make no sub-families, I believe. There is a great deal yet to learn of these sub-families, whose extremes are so dissimilar the ends that approach eacho ther so similar.

\section{Sub-family $a$ PHALERIDIN $\$$}

Puffins and allies

Genera, Fratercula, The True Puffins (3 species).

Lunda, The Tufted Puffin.

Ceratorhina, The Horn-billed Puffin.

Simorhinchus, The Crested and Whiskered Auks.

Phaleris, The Parrot Auk.

Ciceronia, The Least Auk.

Ptycorhamphus, The Aleutian Auk. 


\section{Sub-family $b$ ALCIN王 True Auks}

Nostrils naked and not reached by the feathering at the base of the bill.

Gexera, Alle, Sea Dove, Dovekie.

? Synthliborhamphus, 2 species.

Brachyrhamphus, 5 species.

Uria, The True Guillemots (3 species).

Lomvia, The True Murres (4 species).

Utamania, The Razor-billed Auk.

Alca, The Great Auk.

The above generic equivalents for the Auks and Puffins is correct, as the family is now treated by our best ornithologists. It would be unwise to enter into a discussion of old relations and old synonyms. A very few of them may be mentioned only, such as Alca, Phalaris, Utamania, and Uria, as being general names for the Auks; Normon for the PurFiss; Ceppus and Colymbus for the Black Guillemot and its allies: Colymbus was also used for many of the other species of Guillemots.

WE have omitted, in the above pages, the discussion of a large number of Debatable Questions, especially concerning Individual Species and the admission of genera based upon them. We hope, however, that no essential genus has been left out.

\section{Subjects for Essays.}

Let the pupil Write ax Essay upon any of the following Subjects :

1. The Migrations of Birds.

2. North American Birds found in Europe and other Foreign Countries. 
3. European Birds found in North America.

4. North American Birds found in South America.

5. South American Birds found in North America.

6. Where shall we draw the Line between the North and the South American Avi-fauna?

7. The Avi-fauna of Central America and its Boundaries North and South.

8. The Birds of the West Indies.

9. The Winter Residence of our North American Birds.

10. In the Nests of what Birds does the Cow Bird, Molothrus ater, lay her eggs and how many?

11. Double-yolked Eggs.

12. The Colors of Birds Eggs and how produced? Is there a Law regulating them?

13. Changes of Habits amongst Birds.

14. A Theory of Albinism. Enumeration of Species.

15. A Theory of Melanism. Enumeration of Species.

16. A Theory of Bird Growth. (Size in Old and Young, in Male and Female.)

17. Pneumacity in Birds. [This could be made a very interesting subject for Original investigation].

18. Coloration and Ornamentation in Birds.

19. The Theory of Flight in Birds.

20. Birds that Sing in the Night.

21. Birds that Sing on the Nest.

22. Curiosities of Bird Architecture.

23. Causes of Decrease (or Increase, if observed) in the Abundance of Certain Species of Birds in different Years in the same Area.

24. Extinet Birds.

25. Faunal Areas.

26. Early and Late Arrival and Departure of Birds (in any given Locality) and probable Causes.

27. Variation in Size in Eggs of the same Species.

28. Derivation of Names from Foreign Languages.

Any or all of these Topies can be enlarged indefinitely. 
Most of them can be restricted to North American Birds, or applied to Birds in General. The number of Topies might be increased, also, upon careful consideration. The above, however, will be found to contain most of the leading Questions of the Day, as applied to Ornithological problems.

\section{An Enumeration of the ORDERS and FAMILIES of the BIRDS OF THE WORLD.}

The present list of the Families of THE BIRDs of THE WORLD, following their respective Orders, is the result of over twenty-five years of careful study and reflection. The latest works upon the subject, in both the European and the English Languages are in my Library and have been faithfully examined.

Besides the actual specimens in the Central Park and Vassar College Museums (in 1873), Amherst College, and the Boston Society of Natural History; the magnificent collection of birds, both stuffed and in the skin, of Prof. H. A. Ward of Rochester, N. Y. ; a valuable collection of about 2000 skins of birds from the East Indies, belonging to my brother the late William F. Stearns, Esq. of Orange, N. J. ; a collection of 800 skins from the same source, the property of the Rev. William $\bigcirc$. Ballantine of Ahmednagar, India; besides many smaller collections from various parts of the world which have been opened to me and have been no less interesting.

A discussion of why each family has been placed as it has, would occupy more space than can at present 
be allowed in these pages. A hasty glance at the classification of an eminent English writer, in a recent work just come to my notice, strengthens my conviction that the linear theory of classification is no longer tenable. The idea of direct relationship, from the beginning to the end of the series, through similarity of common features - say of bill, wing, tarsus, etc., which has occupied the mind of ornithologists for over two hundred years, has, by our latest and most eminent authorities, given place to what I will call, to coin a word of my own, The Cubical Theory of relationship and inter-relationship from a central point Aves. Groups of birds, more or less complete in themselves, are so far removed from each other that no recent or fossil forms supply the deficiency. Our ornithological ensemble is, therefore, not a LINEAR one: As a very simple illustration: We have LAND BIRDS and WATER Birds, we have also Game Land Birds and Game Water Birds. We have Fowl among both Land and Water Birds. Then we have a host of PECULIAR FORMS that conform to nothing but themselves. In many ways does this CUBICAL theory of distinct phases of Bird life peculiar in themselves and resembling nothing else, except in being a Bird, show itself throughout the whole Class.

In the following list, the English equivalent for the Latin or Greek name has been faithfully translated; though they do not seem always to fully apply, they are at present the best that we have to offer, and often too familiar to be changed without good reasons. The student would find a great deal of advantage, also, in studying the derivation and meanings of names in Ornithological nomenclature. A few names. brackited 
but not included in the regular families or numbered, are yet made families by some authors. They may in time be given full Family rank, but not now.

It has not been thought necessary to cumber these pages with Sub-Orders or Sub-Families. They are, to a very great extent, useless divisions in Ornithology in any event and seldom stable.

The accompanying Table will serve as a diagnosis of Orders and explain itself. These Orders are given in their order upon the back of the Table. Order 3 should read Macrochires. We may, at a later date, elaborate a diagnosis for the Families.

Order 1. PASSAREs-Sparrow-like Birds.

1 Turdidæ True Thrushes.

2 Troglodytidæe Wrens.

3 Paridæ Titmice.

4 Chamæida Wren-tits.

5 Nectariniidae Sun-Birds.

6 Meliphagida Honey-eaters.

7 Cœrebida Honey-creepers.

8 Certhiida Creeping Warblers.

9 Sylvicolidæ True Warblers.

10 Muscicapidæe Old World Flycatchers.

11 Ampelidae Waxwings.

12 Motacillidæe Wagtails and Pipits.

13 Alaudidze Larks.

14 Hirundinidæ Swallows.

15 Laniidæe True Shrikes.

16 Dicrurida Drongo Shrikes.

17 Vireonidæe Vireos.

18 Oriolidie Orioles.

19 Icterida American Starlings.

20 Sturnidæ Old World Starlings.

21 Corvidae Crows.

22 Ptilonorhynchidæ Bower Biràs. 


\section{A Clas}

Jaw bone provide

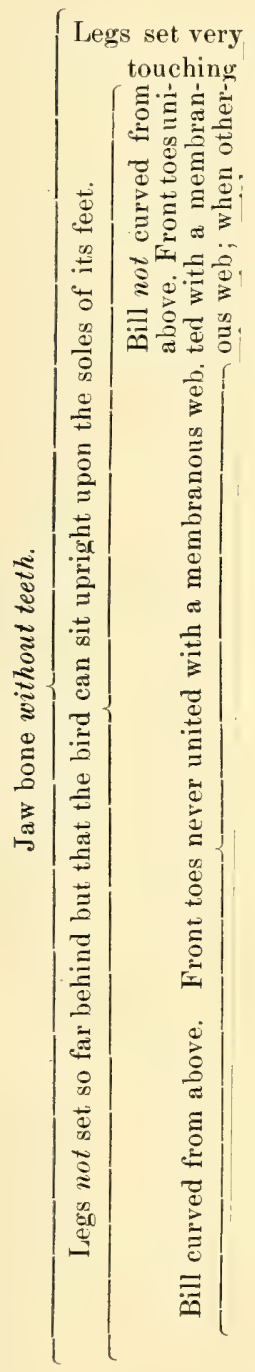

${ }^{1}$ Some auth 


$$
1
$$




\section{A Classification for the Orders of the Birds of the World.}

Jaw bone provided with teeth

16. ODONTORNI'IHES

Toothed Birds.

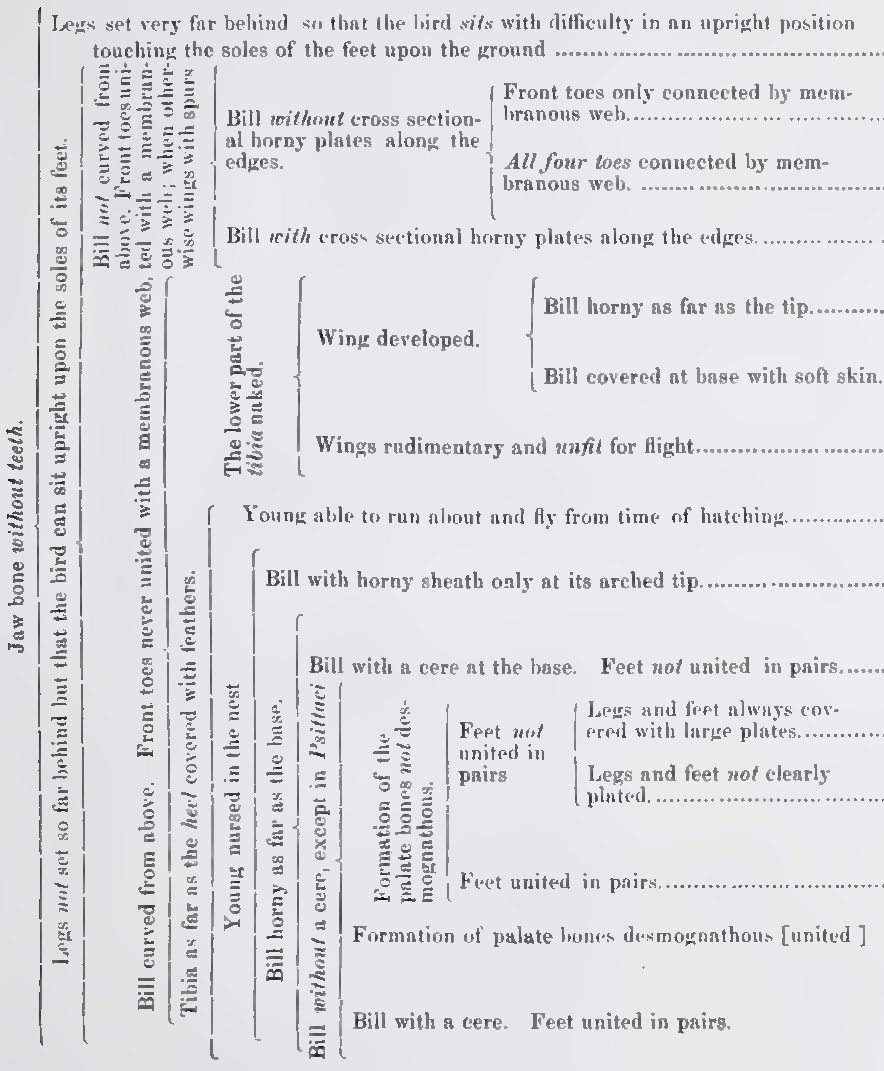

15. PYGOPODHS'

Rump-footed.

13. LONGIPENNES

Long-winged.

12. STEGANOPODES.

Web-footed.

11. LAMELLIROSTRES

Plated-billed.

10. CICONIA.

Storks.

11. GRALLA.

Stilt-walkers.

7. BREVIPENNES

Small-winged,

8. RASORES.

Scratchers.

9. COLLCMBA.

Pigeon-like.

4. RAPTURES.

Birds of Prey.

1. PASSARES.

Sparrow-like.

3 MACROCRIRES.

Long-handed.

6. PICI.

Woodpecters.

2. COCCYGES.

Cuckoos.

5. PSITTACI

Parrots.

1 Some anthors use the nnme Urisatuks for this Order as Pygoyns is the name of a Reptile. 


\section{PASSARES.}

Sparrow-like.

\section{COCCYGES.}

Cuckoos.

3. MACROCRIRES.

Long-handed.

4. RAPTORES.

Birds of Prey.

\section{PSITTACI. Parrots.}

6. PICI. Woodpeckers.

\section{BREVIPENNES.}

Small-winged.

\section{RASORES}

Scratchers.

9. COLUMBE. Pigeon-like.

10. CICONIA. Storks.

11. GRALLÆ. Stilt-walkers.

12. STEGANOPODES.

Web-footed.

13. LONGIPENNES.

Long-winged.

14. LAMELLIROSTRES Plated-billed.

15. PYGOPODES. ${ }^{1}$

Rump-footed.

16. ODONTORNITHES.

Toothed Birds. 
23 Paradiseidæ Paradise Birds.

24 Tanagridæ Tanagers.

25 Fringillidæ Finches.

26 Ploceidæe Weaver Birds.

27 Menuridæe Lyre Bird.

28 Tyrannidæ Tyrant Flycatchers.

29 Cotingidæe Chatterers.

30 Dendrocolaptidæe [SitTA] Tree Creepers.

31 Formicariidze Ant Eaters.

32 Pittidæe Pittas.

Order 2. Coccyges-Cuckoos.

33 Cuculidæe Cuckoos.

34 Alcedinidæe Kingfishers.

35 Coraciadze Rollers.

36 Meropidæ Bee-eaters.

37 Momotidæ Motmots.

38 Upupidæe Hoopoes.

39 Galbulidæ Jacamas.

40 Bucconida Barbets.

41 Rhamphastidæ Toucans.

42 Musophagidæ Plantain Eaters.

43 Bucerotidæ Hornbills.

44 Trogonidæe Trogons.

45 Coliidæ Colies.

Order 3. MACROCHIRES-Long-handed Birds

46 Trochilidæ Hummingbirds.

47 Cypselidæ Swifts,

48 Caprimulgidæ Goatsuckers.

Order 4. RaptoREs-Birds of Prey.

49 Vulturidæe Old World Vultures.

50 Cathartidæ American Vultures.

51 Serpentariidæe Secretary Birds.

52 Falconidæe Hawks and Eagles,

53 Pandionidæe Ospreys.

54 Strigidæe True Owls.

55 Aluconidze Barn Owls. 
Order 5. PsitTACi-Parrots.

56 Strigopidæ Owl Parrots.

57 Psittacidæ True Parrots.

Order 6. PICI-Woodpeckers.

[Picumnidæ.]

58 Picus Woodpeckers.

59 Yungidæe Wrynecks.

Order 7. BREvipennes-Small-winged Birds.

60 Apterygidæ Apteryx.

61 Dinornithidæ, etc. [Extinct.]

[Dromeadidæ Emus.]

[Casuaridæe Cassowaries.]

[Rheidæ Rhea.]

62 Struthionidæe Ostriches, etc.

Order 8. RASORES-Scratching Birds.

63 Tinamidx Tinamous.

64 Meleagridæe Turkeys.

65 Tetraonidze Grouse.

66 Phasianidæ Pheasants.

67 Perdicidæe Quail-like Birds.

68 Pteroclida Wild Hens.

69 Cracidæe Curassows.

Order 9. Columbae-Pigeon-like Birds.

70 Gouridæ Crowned Pigeons.

71 Columbidze True Pigeons.

72 Calœnodidæ Maned Pigeons.

73 Treronida Fruit Pigeons.

74 Didunculidæe Toothed Pigeons.

75 Dididæ Dodo.

Order 10. Ciconia-Storks.

76 Plataleidæ Spoonbills.

77 Ibididæe Ibises.

78 Ciconiidze Storks.

[Scopidz.]

79 Ardeidze Herons. 
Order 11. Grallae-Stilt-walkers.

80 Otididæe Bustards.

81 Gruiidæ Cranes.

82 Psophiidæe Trumpeters.

[Chionididæ.]

[Rhinochetidæ.]

83 Charadridæ Plovers.

84 Scolopacidæe Snipes.

85 Parridæ Jacanas.

86 Rallidæ Rails.

Order 12. Steganopodes-Web-footed Birds.

87 Pelecanidæ Pelicans.

88 Phalacrocoracidæe Cormorants.

89 Sulidæ Gannets.

90 Plotidæe Darters.

91 Tachypetidze Frigate Bird.

92 Phæthontidæ Tropic Birds,

Order 13. Longipennes-Long-winged Birds.

93 Laridæe Gulls.

94 Procellarida Petrels.

Order 14. Lamellirostres-Plated-billed Birds,

95 Palamedeidæ Horned Screamers.

96 Phœnicopteridæ Flamingoes.

97 Cygnidæ Swans.

98 Anseridæ Geese.

99 Plectropteridae Spur-wing.

$$
\text { [Tadornidæ.] }
$$

100 Anatidæe River Ducks.

101 Fuligulidæe Sea Ducks.

102 Erismaturidæe Ruddy Ducks.

103 Mergidæe Fish Ducks.

Order 15. Pygopodes-Diving Birds.

104 Colymbidæe Divers.

105 Alcidæ Auks.

106 Spheniscidæe Penguins. 
Order 16. Odontornithes-Toothed Birds Extinct.

\section{Hesperornithes}

108 Ichthyornithes Fish-like.

109 Saururæ Lizard-tails.

\section{Glossary of Scientific Terms.}

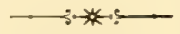

A.

Abdomen, the lower part of the belly.

Aberrant, a deviation from some typical form.

Abnormal, not normal or regular, irregular.

Abortive, not perfect or fully grown.

Abrupt, with the appearance of having been suddenly broken or cut off, ending suddenly.

Acicular, when the whole bill is of nearly the same width and thickness from the base to the tip, which is pointed abruptly ; differs from attenuated and acuminate, in that these latter begin large and dwindle gradually to a fine, sharp point.

Acuminate, short, slender, and tapering to a sharp point.

Acute, sharp-pointed.

Aerial, pertaining to the air.

Affinity, having a likeness to.

After-shaft, the supplemental part of the shaft of a feather, that which bears the web, or "feather web."

Albino, a white condition of some different colored plumage. Attenuate, long, slender, and tapering to a sharp point.

Altrices, birds which rear their young in the nest.

Alula, the little or "spurious" wing, the thumb.

Anal regions, the regions abont the anus.

Angulated, meeting at an angle. 
Ankle, the heel joint,

Anterior, in front.

Antrose, directed forward.

Anus, the lower opening of the body.

Apex, the point or upper end.

Aquatic, pertaining to or living in the water.

Arched, convexed.

Auricular, pertaining to the ear, the region just above the ear. Avi-fauna, bird fauna.

Axillary, belonging to the axilla or arm-pit. [The inner under wing-coverts are called the axillary coverts.]

B.

Barbs, the small branch- or hook-like portions of a feather.

Barbules, the small branch- or hook-like portions of the barbs.

Basal, when situated at the base.

Bastard wing, SeE Alula.

Bifid, having two divisions or parts, divided into two parts.

Bilobate, having two lobes.

Booted, showing a smooth, plain surface or single, large plate, - neither scutellate or reticulate.

Boreal, applied to species dwelling mostly in the far Northern latitudes.

\section{C.}

Caniculate, furnished with a groove or channel.

Carinate, keeled, like the inverted keel of a ship.

Carnivorous, flesh-eating.

Carpus, the wrist ; carpal, pertaining to the wrist.

Caruncles, - of fowl, etc., - fleshy outgrowths.

Caudal, pertaining to the tail.

Cere, the naked [wax-like] membrane at the base of the bill of many birds, especially of hawks, parrots, etc.

Cervix, SeE Neck; cervical, pertaining to the hind neck.

Cheeks, the sides of the head below the eye, (between the anricular patch and basal point of the upper mandible.)

Circular, round.

Clavate, elub-shaped. 
Cleft, cut into, (incised.)

Coalesce, to join together.

Coccyx, the last bone of the tail.

Combs, - of fowl, etc., - fleshy outgrowths, fleshy head crests. Commissure, the angle of the mouth behind (when the bill is open), often [wrongly] applied to the whole edge from tip of mandible to the angle.

Compressed, flattened in a perpendicular direction.

Concave, hollowed toward the centre.

Conical, cone-shaped.

Conirostres, birds in which the bill is conical (sparrow-like).

Contour, the shape, ontline, or outward form of anything.

Contracted, suddenly grown or made smaller in any direction.

Convex, swelled or bulged from the center ontward.

Coriaceous, tough like leather.

Corneous, hard and horny.

Corrugated, roughened, wrinkled.

Coterts, small feathers covering the base of some growths of larger feathers: there are the primary coverts, the secondary coverts, and the tertiary coverts; the greater coverts and the lesser coverts; the upper coverts and the under coverts, ete.

Crenulate, wavy edged.

Crest, a portion of the feathers of the body which are, (being somewhat elongated) or are capable of being, raised above the surface of the surrounding feathers. Crests properly belong to the head.

Crisum, the region between the amm and the base of the under tail coverts.

Crown, of the head, the central portion.

Crus, that portion of the leg represented by the tibia and the fibula taken together.

Culmen, the highest median line of the upper mandible.

Culminate, where the upper edges of any thing join each other. Cultirostres, birds in which the bill is of a cutting, knifeshaped shape (Heron-like). 
Cuneiform, wedge-shaped.

Cutanaceous, pertaining to the skin, skinny.

Cuticle, hardened portions of the skin.

Cylindrical, shaped like a cylinder.

D.

Decurved, curved downwards.

Dentate, toothed.

Dentirostres, birds in which the bill is lobed or toothed at the tip, (Flycatcher-like.)

Denuded, rendered nude or bare in any part.

Depressed, flattened in a horizontal direction.

Dermal, pertaining to the skin.

Dew-laps, fleshy or skinny outgrowths.

Diagnosis, a brief description of the marks which distinguish one Order, Family, Genus, Species, ete., from another.

Digit, any one of the phalanges (or fingers proper).

Digitigrade, - amongst birds - walking on the toes of the feet in distinction from plantigrade.

Dilated, enlarged, swelled or bulged out.

Disc, a more or less circular, plate-like arrangement of radiating feathers, - shown especially about the eyes of $\mathrm{Ow}_{\mathrm{w}}$ and other Birds of Prey.

Divaricate, spreading out (or fan-like) from some common stem or centre.

Dorsal, pertaining to the back.

\section{E.}

Elbow, the outer joint of the humerus.

Elliptical, an oval about twice as long as wide.

Emarginate, notched, cut into, as if a piece had been cut out.

Epidermis, the outer layer of the skin.

Epignathous, when the tip of the upper mandible is bent over that of the under.

Epiphysis, (pl. epiphyses), the caps to the limb bones.

Esophagus, the gullet, the channel leading into the stomach. Also spelled Esophagus.

Excoriaceous, a state in which the skin seems to come off in small scale-like particles. 
Exserted, projecting beyond the rest.

Exterior, upon the outside.

$\mathbf{F}$.

Facial, pertaining to the face.

Falcate, sharp and sythe-shaped.

Fasciculate, covered with little bunches or tufts of fine and often stiff hairs or feathers.

Fauna, the birds (or other animals) of any given region : (distinguished from the flora or plant life.)

Feather's, true feathers have a shaft (with an after-shaft) and a web: feathers may also be downy, thread-like, hairy, or bristly, (or real bristles). The so-called powder-down of some birds is really a kind of feather.

Femur, the thigh bone.

Fibula, the outer leg bone. SeE Tibia.

Filaments, small thread-like growths.

Fissirostres, birds in which the bill is short and has a very wide eleft or gape. (Swallow-like.)

Flanks, the sides of the rump.

Flaps, SEe Dew-laps, fleshy outgrowths.

Fluttened, made flat - longer than wide or wider than long given a flat surface anywhere [a word very common yet very indefinite.]

Flexible, bending easily.

Forficate, deeply forked.

Fosser, masal, the grooves in which the nostrils open, often called sulca (when very long).

Frontal regions, the forehead.

Fuliginous, sooty or smoke colored, smoky-brown.

Fulvous, a tawny yellow color, yellowish-brown.

Fuscous, a darkish or blackish-brown color.

Fused, two or more portions of anything firmly united.

G.

Crape, the line from the tip of bill to the angle of rommissure. Globular, round.

Cronys, the point where the rani of the under mandible join, 
the line of the gonys is often distinct to the very tip of the bill; (they are very variable in shape.)

Graduated, implying that the quills are graded or so arranged that each will be shorter than the one next to it.

Granivorous, grain-eating.

Granular, composed of small grains or granules.

Gregarious, living or assembling together in flocks.

Gula region, SEE.Throat.

Gullet, SEE Esophagus.

H.

Habitat, the place or region which any species peculiarly inabits.

Hallux, the hind toe.

Hamulate, hooked.

Heel, practically the elbow, the joint of the tibia and tarsus.

Horny, hard, tough, and flexible, like horn.

Humerus, the bone of the arm from the shoulder to the elbow. Hybrid," a cross between two different species.

Hypognathous, in which the lower mandible is longer than the upper mandible.

I.

Imbricate, furnished with scales or plates which overlap each other, similar to the shingles upon the roof of a house.

Immaculate, unspotted.

Impervious, not apparently pervious or open, shut up.

Incised, cut into.

Incumbent, where one portion lies upon another (when the whole surface of the toes or feet lie upon the ground when the bird is standing).

Inferior, when below any given line or point, as inferior to the median line.

Inflated, swelled out, distended.

Insistent, - of bird's feet, when only the toes lie upon the ground when the bird is standing (or of the hind toe when raised above a level of the others just so much that only the end of the toe can touch the ground).

Interior, within, inside of. 
$\mathbf{J}$.

Jugulum, SEE Throat.

K.

Keeled, having a raised, central ridge like the inverted keel of a ship.

Knee, practically the joint of the femur and the fibula.

L.

Lamelloe, thin plate- or scale-like processes.

Lamellirostres, birds in which the bill is furnished with lamellae

(Duck-like).

Lanceolate, shaped like the head of a lance.

Larynx, the upper part of the trachea or windpipe, from the lower part of which proceed the laryngeal or the singing muscles.

Lateral, pertaining to the side or sides.

Latitudinal, long, - in height.

Linear, like a line, long and narrow.

Lobate, furnished with a series of lobes or flaps along the sides of each toe.

Lobes, fleshy outgrowths (of membrane).

Longirostres, birds in which the bill is long but stout (Snipelike).

Longitudinal, long lengthwise.

Lores or Loral regions, the spaces between the eye and the base of the upper mandible, on either side of the head.

M.

Maculate, spotted.

Malar, pertaining to the cheek.

Mandibles, the upper and under sheaths of the bill.

Mantle, - in gulls, etc., the upper surface of the wings and back taken as a whole.

Maxillary line, the line at the base of the jaws or mandibles. [The word maxillary is seldom used in Ornithology, being interchangeable with mandible; it refers, really, to the secondary jaws of Insects.]

Median, middle. 
Melano, a black variation of some different colored plumage. Membranaceous - membrane - covered with or having a membrane or skinny covering.

Mentum, the chin.

Metacarpus, that portion which lies between the carpus and the phalanges.

Metagnathous, a state in which the points of both mandibles cross one another.

Metamorphosis, a change of form, shape, or structure.

Migrant, (Migration,) (Migratory,) the passing from one region to another at stated intervals, usually in both Spring and Autumn : cause - temperature, food, etc. Morphology, treats of the forms of any given animal structure. Moult, the shedding of the old and the acquiring of the new plumage (occurs once and often twice each year.)

Mucronate, abruptly pointed by a sharp, spiney shaft.

N.

Nasal, pertaining to the nostrils.

Nape, SeE Neck.

Neck, The, the neck of a bird is really divided into three regions : the occiput, just back of the crown of the head; the neuchal region, or nape; and the hind neck or cervix. The NAPE is often spoken of as the back of the neck, and it lies between the occiput and the cervix.

Neuchal region, SEE Neck.

Nidify, Nidification, to nest, to make a nest, the process of nesting.

Normal, regular, ordinary.

Nude, naked.

Oblique, stanting, inclined.

o.

Oblong, longer than wide.

Obtuse, not sharp-pointed (blunt).

Occiput, SeE Neck.

Omnivorous, the eating of all kinds of food indiscriminately.

Orbital region, the region about the eye. 


\section{MANUAL}

ed.

Ovate, rounder, but longer than wide.

Ovoid, shaped like an egg, egg-shaped.

$\mathbf{P}$.

Palmate, webbed (the web may be more or less incised, or cut into, but always reaches to the base of the claws).

Papillac, little raised knobs.

Paragnathous, birds in which both mandibles are of equal length.

Patella, the little bone at the cap of the knce, the "knee-cap." Pectal regions, regions of the breast.

Pectinate, furnished with teeth, like a comb.

Pectoral, pertaining to the bruast.

Pennce, Pennate, Pennaceous, refers to the small feathers of a bird, often called contour or down feathers, which constitute the main part of the plumage.

Perforated, open from one side to the other, pierced by one or more openings.

Pervious, provided with holes, opened.

Phalanges, the fingers, or that part of the wing which answers to the fingers.

Pinion, a feather, or quill, - thus often the whole wing.

Plantigrade, walking with the soles of the feet on the ground. Plume, a single feather, a small bunch of peculiar feathers.

Plumule, diminutive of Plume.

Podotheca, the naked part of the leg.

Posterior, behind, (back of.)

Postorbital, behind the eye.

Precoces, birds that run about and pick up their food from the time they are hatched.

Pessirostres, birds in which the bill is short and well compressed, (Plover-like.)

Primary quills, Primaries, the quill feathers of the last joint of a wing of a bird - often called the hand.

Pubescent, covered with down, downy:

Punctate, covered with punctures, pitted.

Pyramidal, pyramid-shaped. 


\section{OF ORNITHOLOGY}

$\mathbf{R}$.

Rachis, the shaft of a feather.

Radius, the inner of the two bones of the forearm.

Rami, the branches (upon the under side) of the under man dible.

Recurved, curved upward.

Remiges, the long, true quills of a bird's wing — and including the primaries, the secondaries, and the tertiaries.

Remote, said of the hind toe when it is situated so far above the others that its tip cannot reach the ground.

Reticulate, covered with very smal! plate-like scales which are of various (irregular) sizes and shapes, not imbricated.

Retrose, directed backwards.

Rictus, the line from the base of the bill to the point of the commissure, (inner angle of gape.)

Rigid, stiff, inflexible, or not easily bent.

Rostrum, the bill, the beak.

Rounded, round, but not necessarily completely so.

Ruff, a collection of feathers standing out at an angle from the rest of the surrounding plumage.

Rufous, a reddish-brown color.

Rugose, covered with irregular elevations - roughened irregularly, (having a surface resembling sandpaper but more irregular.)

Rump, the region just above the extremity of the backbone and near to the base of the tail.

S.

Sagittate, arrow-shaped.

Scabrous, roughened with scab-like scales.

Scapularies, the feathers springing from the shoulder-blade or Scapula, (the shoulder of the wing.)

Scurf, the dry external scales of the skin (or epidermis).

Scutellate, covered with plate-like scales or scutellæ, and generally so arranged that one overlaps the other like the shingles of a house roof.

Secondary quills, Secondaries, the quill feathers of the forearm of" a bird. 
Semipalmate, partly- or half-palmate or webbed.

Serrate, saw-shaped (having teeth like a saw).

Sessile, attached directly to anything, without a "foot-stalk."

Setce, small bristly tufts of fine hairs or feathers.

Shaft, the tough central stem of a feather, bence the whole feather often.

Sheath, the horny covering of each mandible.

Sinuate, waved or wavy in outline.

Spatulate, flattened and then widened at the end.

Speculum, the peculiar mirror-like appearance often noticed on the wings of many species of ducks and other birds.

Spinous, covered with stiff bristles, more or less spiney.

Spurious, false, or small compared to other things of the same kind and nature; imperfect, incomplete.

Sternum, the breast bone.

Strice, streaks, streaked, striated.

Sub-basal, halfway between the base and the middle of a thing. Subulate, awl-shaped.

Sub-terminal, halfway between the middle and the point or end of a thing.

Sulcate, grooved or furrowed.

Superciliary line, the line [or $a$ line] just above the eye.

Superior, when represented as being above any given line, usually the median line.

Synonym [synonymoux. literally THE SAME AS: when any two different names are applied to the same ORDER, FAMILY, GENUS, or sPECIES, or particular part of a bird, the one is called a synonym of the other, or the two are synonymous. It refers especially to the scientific names for each individual species.

\section{T.}

Tarsus, the bone from the heel to the base of the toes (really the meta-tarsus).

Temporal region, the region of the temples.

Tenuirostres, birds in which the bill is long, slender, and with short gape (Humming-bird-like). 
Terete, nearly cylindrical, having the transverse section nearly circular.

Terminal, at the end.

Terrestrial, pertaining to the ground.

Tertiary quills, Tertiaries, the quill feathers of the upper arm.

Thigh, the thigh of a bird is represented by the femur or thighbone.

Throat, the throat of a bird is, really, divided into 2 regions : the upper or gula region, and the lower or jugulum.

Thumb, the small outer bone of the wing, also called bastard wing or alula " little wing."

Tibia, the inner leg bone (both tibia and fibula are usually spoken of together as the tibia in describing birds).

Tomia, the cutting edges of the mandibles.

Totipalmate, fully or wholly webbed (not incised anywhere).

Trachea, the windpipe.

Transverse, crosswise, up and down.

Trifid, having three divisions or parts, divided into three parts.

Trilobate, tbree lobed.

Truncate, eut or broken off at the top.

Tubercles, small wart-like raised surfaces on the skin.

Tubular, having the shape of a tube.

Tumid, rough and uneved, swelled out, (with skin soft.)

Turgid, rough and uneven, swelled out, (with skin hard.)

Typical, a Type, a specimen best illustrating any given group or series, or series of groups.

\section{U.}

Ulna, the outer of the two bones of the forearm.

Unguiculate, claw-like.

Unguis, the nail (applied to the bill and sometimes the claw).

Upper tail coverts, upper wing coverts: the small feathers covering the base of the tail or wing above; under tail coverts, under wing coverts, the same below.

\section{$\mathrm{V}$.}

Vaulted, arched (like the roof of the mouth).

Vascular, furnished with little pits (like the extremity of a Snipe's bill). 
Vent, See Anus.

Ventral regions, the regions about the vent.

Versatile, capable of being turned either backward or forward.

Vexillum, the web or vein of a feather (each true feather has two of them).

Villose, covered with fine hairs, hairy.

W.

Wattles, of fowls, etc., - fleshy outgrowths.

$\mathrm{Web}$, - of a feather - the closely connected feathery ends of each vexillum (vein or side) of a feather; Web-footed, when the toes are connected, more or less, by a web or lobe (membrane).

Y.

Young-of-the-Year, this expression is often used to signify "a young bird not a year old and moulting."-MAYNARD.

$\mathbf{Z}$.

Zygodactyle, having two toes in front and two behind. 


\section{Systematic ArRangement.}

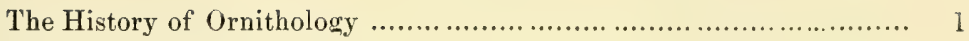

Group Aves or Birds.................................................... 23

Sub-group Aves Ratitce................................................... 23

Sub-group Aves Carinatce................................................. 23

Sub-Class Arial Birds or Insessores.................................... 24

Sub-Class Terrestrial Birds or Cursores................................. 24

Sub-Class Aquatic Birds or Natatores.................................. 24

Order 1 Passares..................................................... 25

Sab-Order 1 Oscines or Singing Birds............................ 25

Sub-Order 2 Clamatores or Screaming Birds..................... 25

Order 2 Picarice......................................................... 26

Sub-Order 1 Cypseli or Swift-like Birds......................... 26

Sub-Order 2 Cuculi or Cuckoo-like Birds......................... 26

Sub-Order 3 Pici or Woodpecker-like Birds. ...................... 27

Order 3 Psittaci..................................................... 27

Order 4 Raptores.................................................... 27

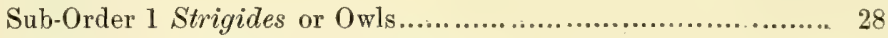

Sub-Order 2 Accipitres or Hawks............................. 29

Sub-Order 3 Cathartides or Vultures............................ 29

Order 5 Columba ........................................................... 29

Order 6 Gallina........................................................ 30

Order 7 Grallatores....................................................... 31

Sub-Order 1 Limicolae or Shore Birds........................... 31

Sub-Order 2 Heriodiones or Herons................................ 32

Sub-Order 3 Alectorides or Cranes.............................. 32

Order 8 Lamellirostres............................................... 33

Sub-Order 1 Phonicopterides or Flamingoes...................... 34

Sub-Order 2 Anseres or Ducks, Geese, ete........................ 34

Order 9 Steganopodes................................................. 34

Order 10 Longipennes............................................. 34

Sub-Order 1 Larides or Gulls and Terns......................... 35

Sub-Order 2 Procellarides or Petrels............................... 35

Order 11 Pygopodes.................................................. 35

Other Systems...................................................... 36

I. LAND BIRDS ................................................... 39

Family 1 Turdidce, The Thrushes..................................... 39

Sub-family a Turdince, True Thrushes........................... 40

b Mimince, Mocking Thrushes......................... 41

c Cinclince, Dippers.................................... $4 \mathrm{I}$ 
d Saxicolino, Chats

e Reyulince, Kinglets................................ 42

f Polioptilince, Gnat-catchers......................... 42

Family 2 Chamceidce, The Wren Tits.................................. 42

3 Paridce, The Titmice, Chickadees............................. 43

4 Sittidee, The Nuthatches..................................... 44

5 Certhiide, The Creepers....................................... 44

6 Troglodytidee, The Wrens..................................... 45

Sub-family a Campylorhynchino, Fan-tails...................... 45

b Troglodytince, True Wrens......................... 45

Family 7 Alaudidee, The Larks....................................... 46

8 Motacillide, The Wagtails, Titlarks......................... 47

Sub-family a Motacillince, True Meadow Wagtails.................. 48

b Anthina, Titlarks.................................. 48

Family 9 Sylvicolida, The Warblers................................... 49

Sub-family $a$ Sylvicolince, True Warblers......................... 52

$b$ Icteriina, Chats.................................. 54

c Setophaqince. Flycatching Warblers.................. 54

Family 10 Corebide, The Honey Creepers................................ 55

11 Tanagrida, The Tanagers............................... 56

12 Hirundinida, The Swallows............................. 56

13 Ampelide, The Waxwings.................................. 57

Sub-family a Ampelince, Waxwings.............................. 58

$b$ Ptiliogonidince..................................... 58

c Myiadestince.......................................... 58

Family 14 Laniida, The Shrikes...................................... 59

15 Vireonida, The Vireos or Greenlets......................... 59

16 Fringillida, The Finches and Sparrows..................... 60

17 Icteridce, The Blackbirds, etc................................ 67

Sib-family a Agelain $x$, Blackbirds............................. 68

b Sturnellina, Starlings............................. 68

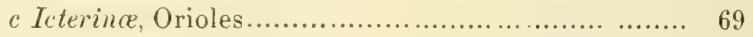

d Quiscalince, Grackles............................... 69

Family 18 Corvide, The Crows and Jays................................. 70

Sub-family a Corvince, True Crows............................... 71

$b$ Garrulina, Jass ................................... 71

Family 19 Tyrannidee, The Flycatehers ............................ 72

20 Caprimulgida, The Goatsuckers........................... 74

21 Cypselida, The Swifts...................................... 75

Sub-family a Cypselince, True Swifts........................... 76

b Choturince, Swallow Swifts ....................... 76

Family 22 Trochilida, The Humming Birds........................... 76

Family 23 Trogonidee, The Trogons................................. 77

24 Alcedinidae, The Kingfishers............................... 78

Cuculider, The Cuckoos......................................... $\quad 79$ 


\section{OF ORNITHOLOGY}

Sub-family a Crotophaginae, Anis....

$b$ Saurotherinae, Ground Cuckoos....................... 80

c Coccyginae, True Cuckoos........................... 80

Family 26 Picidae, The Woodpeckers................................. 8]

27 Psittacidae, The Parrots.................................. 82

28 Aluconidae, The Barn Owls.................................. 83

29 Strigidae, Owls in general................................. 84

Sub-family a Buboninae, Horned Owls............................. 85

b Syrninae, Gray Owls................................ 85

c Atheninae, Bird Owls ............................. 86

d Nycteininae, Day Owls.............................. 86

Family 30 Falconidae, The Falcons, Hawks, and Eagles................. 86

Sub-family a Circinae, Harriers.................................. 87

b Milvinae, Kites...................................... 88

c Accipitrinae, True Hawks.......................... 88

d Falconinae, True Falcons.......................... 89

e Polyborinae, Caracara Eagles......................... 90

$f$ Buteoninae, Buzzard Hawks........................ 91

$g$ Aguilinae, Eagles .................................. 92

Family 31 Pandionidae, The Ospreys.................................. 92

32 Cathartidae, The Vultures................................... 93

33 Columbidae, The Pigeons.................................... 94

Sub-family a Columbinae, True Pigeons.......................... 94

$b$ Zenaidinae, True or Ground Doves .................... 94

c Starnonidinae...................................... 95

Family 34 Cracidae, The Curassow or Guan........................... 95

35 Meleagridae, The Wild Turkeys............................ 96

36 Tetruonidae, The Partridge, Grouse, and Quail.............. 96

Sub-family a T'etraoninae, Grouse............................... 97

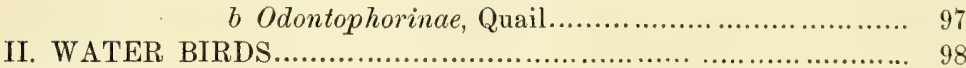

Family 37 Charadriidae, The Plovers................................... 100

38 Homatopodidae, The Oyster-catchers and Turnstones....... 101

Sub-family a Haematopodinae, Oyster-catchers..................... 102

b Strepsilainae, Turnstones........................... 102

Family 39 Recurvirostridae, The Arocets and Stilts..................... 102

40 Phalaropodidae, The Phalaropes............................. 103

41 Scolopacidae, The Snipes and Sandpipers................... 103

42 Ibididae, The True Ibises............................... 109

43 Plataleidae, The Spoonbills................................. 110

44 Ciconiidae, The Storks........................................ 110

Sub-family a Tantalinae, Wood Ibises.......................... 110

b Ciconiinae, True Storks.............................. 110

Family 45 Ardeidae, The Herons....................................... 110

Sub-family a Ardeinae, True Herons........................... 111 
b Botaurinue, Bitterns..................................... 112

Family 46 Gruidae, The Cranes.................................................. 112

47 Aramidae, The Courlans............................................. 113

48 Parridae, The Jaçana................................................ 113

49 Rallidae, The Rails, Gallinules, and Coots....................... 114

Sub-family a Rallinae, True Rails..................................... 115

$b$ Gallinulinae, Gallinules............................... 115

c Fulicinae, Coots........................................... 116

Family 50 Phoenicopteridae, The Flamingoes ............................... 116

Family 51 Anatidae, The Swans, Geese, and Ducks ....................... 117

Sub-family a Cygninae, Swans.......................................... 119

b Anatinae, River Ducks ................................. 120

c Fuligulinae, Sea Ducks................................... 121

d Merginae, Mergansers .................................... 123

Family 52 Sulidae, The Gannets............................................... 124

53 Pelecanidae, The Pelicans ...................................... 124

54 Phalacrocoracidae, The Cormorants............................ 125

55 Plotidae, The Darters ................................................ 126

56 Tachypetidae, The Frigate Bird................................... 126

57 Phcetonidae, The Tropic Bird ................................... 127

58 Laridae, The Gulls and Terns...................................... 128

Sub-family a Lestridinae, Skua or Jager Gull......................... 130

b Larinae, True Gulls.................................... 131

e Sterninae, Terns............................................ 131

d Rhynchopinae, Skimmers................................ 132

Family 59 Procellaridae, The Petrels...................................... 133

Sub-family a Diomedeinae, Albatrosses................................ 133

b Procellarinae, Petrels...................................... 134

Family 60 Colymbidae, The Loons........................................... 135

61 Podicipidae, The Grebes.......................................... 135

62 Alcidae, The Auks and Puffins................................. 136

Sub-family a Phaleridinae, Puffins and allies. ...................... 137

b Alcinae, True Auks.......................................... 138

Subjecs for Essays............................................................... 138

An Enumeration of the Orders and Families of the Birds of the

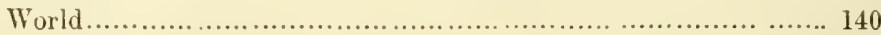

Glossary of Scientific Terms............................................... 146 


\section{INDEX TO GENERA.}

Accipiter ................. 88

Actiturus ..................... 108

Actodromas.................... 108

Actodromus ...............107

Echmophorus ................136

Agialites.................... 101

Egiothus ................63, 66

Aisalon ...................90

Athyia ...................... 122

Agelæus ..................6 68

Agelaius...................6 68

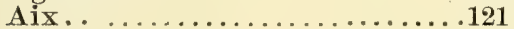

Ajaja.....................110

Alauda.................47, 48

Alca........................138

Alcedo................... 79

Alle.........................138

Aluco.................... 84

Amazilia.................. 77

Ampelis ................. 58

Ammodramus.............66 66

Ammodromas...............64

Amphelocoma............... 71

Amphispiza...............66 66

Anas.................120, 121, 122

Ancylochilus............107, 108

Anorthura .................. 46

Anous................... 132

Anser................... 120

Antenor .................91,92

Anthus .................. 48

Antrostomus............... 75

Aphriza ......................101

Aquila ................... 92

Aramus...................113

Archibuteo..................91

Ardea...............111, 112, 113

Ardeola ...................112

Ardetta ... . .....................

Aretonetta.................. 123

Aristonetta ................ 122

Arquatella..............107, 108

Asio ..................85, 86

Astragalinus ............... 66

Astur..... . . . . . . ........ 88

Asturina.................. 91

Athene ................... 86

Atricilla ................... 131

Attagen ................. 127

Atthis ................... 77

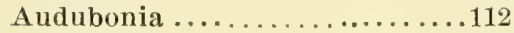

Auriparus................ 43

Aythya.................. 122, 123

Bartramia .................. 109

Basilinna ............... 77

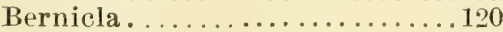

Bombycilla ............... 5s

Bonasa................. 97

Botaurus ..................... 112
Brachyotus ............... 85

Bubo .................... 85

Bucephala .................. 123

Budytes .................. 48

Buphagus .................. 130

Buteo..................91, 92

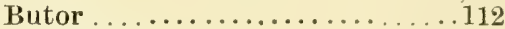

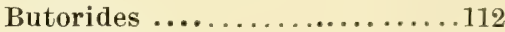

Calamospiza ..............65, 66

Calidris...............107, 108

Callipepla ................ 97

Calothorax............... 77

Calypte..................... 77

Campephilus ................ 82

Camptolæmus .................122

Campylorhynchus ............ 45

Canace................... 97

Caprimulgus............... 75

Carbo......................... 126

Cardinalis...............6. 65,66

Cardellina .................. 52, 55

Carpodacus . . .............63, 66

Catarracta............... 130

Catharista................... 93

Cathartes ................... 93

Catherpes ................. 45

Centrocercus................ 97

Centronyx ................6 64

Centrophanes .............. 66

Centurus..................... 82

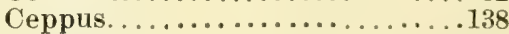

Ceratorhina................... 137

Certhia..................... 45

Certhiola ................. 55

Ceryle..................... 79

Chætura..................... 76

Chamxa .................. 43

Chamæpelia ............... 94

Charadrius .......................... 101

Chaulelasmus.................121

Chen ...................... 120

Chondestes ................64, 66

Chordeiles................ 75

Chroicocephalus ............... 131

Chrysomitris .............68, 66

Ciceronia ............................

Cichlopsis................ 58

Cinclus .................. 41

Circus ...................... s8

Cistothorus. . . . . . . . . . . 46

Claugula.............. 1292, 123

Coccygus.................... 80

Colaptes ................ 82

Collurio .................... ถุ

Collyrio.................... 59

Columba.................94, 95

Colymbus .............135, 136, 138

Contopus ................... 74

Conurus .................. 83 
INDEX TO GENERA.

Corvus.................. 71

Coturnicops ................... 115

Coturniculus.............64, 66

Coturnyx................... 98

Cotyle.................... 57

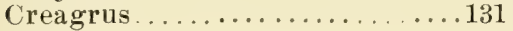

Creciscus......................115

Crex ....................115

Crotophaga ................ 80

Cuculus.................. 80

Culicivora ................. 72

Cupidonia.................. 97

Curvirostra.................. 63

Cyanecula .................. 42

Cyanocitta ................. 71

Cyanospiza...............6. 65

Cyanura ................... 71

Cyanurus ................. 71

Cygnus .................... 119

Cymochorea... . . . . . . . . . . . . 134

Cypseloides ................. 76

Cypselus.................... 76

Cyrtonyx ................. 97

Cyrtopelicanus ..............125

Dafila......................... 121

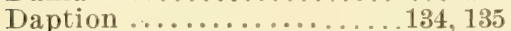

Dendrocycna ................120

Dendrocygna ...........120,121

Dendroeca ............... 52, 53

Dendroica ................... 53

Dendronessa ..............120, 121

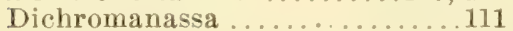

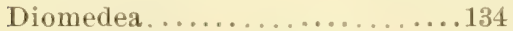

Dolychonyx ...............68

Dysporus .................. 1:t

Dytes ........................ 136

Ectopistes ................. 94

Egretta ................... 112

Elanoides.................. 88

Elanus ............... ss

Embernagra...............65, 66

Empidonax .............. $7 t$

Engyptila ................. 94

Eniconetta ................ . .

Eremophila ................ . 47

Ereunetes .............. 107, 108

Erionetta .................. . . . . . . . . . . . . .

Frismatura . . . . . . . . . . . 10.?

Erolia .................... 107

Eudocimus ................. 109

Eudites .................... 135

Eudytes .................... 135

Eugenes ....................

Euphonia ................. 56

Eurynorbynchus............ 108

Euspiza...................65

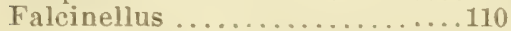

Falco ................ 88, 89, 90

Florida ..................112

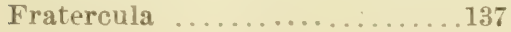

Fregata.................. 127
Fregetta ..............134, 135

Fulica ...................116

Fuligula ................... 122

Fulix ................... 122

Fulmarus...............134, 135

(ialeoscoptes...............44 41

Gallinago ..............107, 108

Gallinula .................. 115, 116

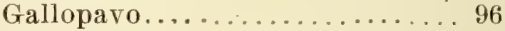

Giambetta .................... 108

Garrulus ..................... 71

Garzetta ................. 111, 112

Gelochelidon .............. 132

Geococcyx ................. 80

Geothlypis ...........52,53,54

Geotrygon................. . 94

Glaucidium ................ 86

Glottis ................. i08

Graculus...................126

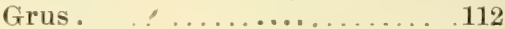

Guiraca ...............65, 66

Gymnocitta................ 71

Gymnokitta................71

Himatopus............... . . . . . . .

Haliætus ...............90, 92

Haliplana.................. 132

Halocy ptena . .............. 134

Harelda. .............. 122

Harporhynehus............. 41

Helmintherus ............. . 53

Helminthotherus ........... 53

Helminthophaga ............ 53

Helminthophila............. 53

Helmitherus............. 52, 53

Helonaa.................. 53

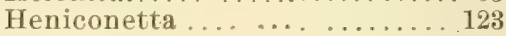

Herodias ..............111, 112

Hesperiphona ..............62, 65

Hesperocichla............... 40

Heteroscelus ..........107, 108, 109

Hierotalco. . . . . . . . . . . . . . . . 90 90

Himantopus. . . . . . . . . . . . . 102

Hirundo ..............57, 75

Histrionicus. . . . . . . . . . . 122, 123

Hydranassa................. 111

Hydrochelidon. ............. 132

Hylucichla ................ 40

Hylotomus ................ 82

Iache .................. 77

Ibis . . . . . . . . . . . . . . . . . . 110

Icteria ..............52, 54

Icterus. . . . . . . . . . . . . . . 69

Ietinia. ................ . . 88

Ionornis . . . . . . . . . . 115, 116

Iridoprocne............... 57

Jacana (SEE PARRA)......... 114

Junco.................64, 66

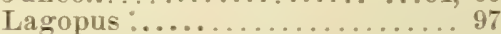

Lampronessa....................... 121

Lampronetta ............. 122, 123

Lanius. 
INDEX TO GENERA.

Lanivireo. . . . ........... \$9

Laroides ..............................

Larus........... . .............. . 131

Lepturus................... 128

Lestris. ...............130

Leucosticte................ 63, 66

Leucus ................. 131

Limosa.... . . . . . . . . . . 106, 108

Linota.................... 66

Lobipes....................... 103

Lomvia .................. 138

Lophodytes .............. 123

Lophophanes .............43

Lophortyx. ............. 97

Loxia.... . . . . . . . . . . . 66

Lunda ...........................

Machet s..................... 109

Macrorhamphus .... . 106, 107, 108

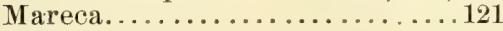

Megalestris . .................. 130

Melanerpes ................. 82

Melanetta ..............122, 123

Melanitta............................

Meleagris .................. 96

Melopelia.................. 94

Melospiza..............64, 66

Merganser..................123

Mergus ..............................

Merula..................... 40

Micrathene ................. 86

Micropalama ..........106, 107, 108

Milvulus ................. 74

Milvus.................. 88

Mimus.................40, 41

Mniotilta...............52,53

Molothrus.................6 68

Momotus ................. 78

Mormon ...........................

Motacilla ................. 48

Mycteria .................. 110

Myiadestes .........42,58,59, 72

Myiarchus.................. 74

Myiodioctes.............52, 55

Myiodynastes ...............74

Myiozetetes.............. 74

Nauclerus .................. 88

Neocorys .................... 48

Nephœeetes................ 76

Nettion....................121

Nomonyx................... 122

Notherodius.....................113

Numenius. . ................. 109

Nyctale................... 85

Nyctea .................. 86

Nyctherodias .................112

Nyetiardea .....................112

Nyetidromus............... 75

Oceanites................... 134

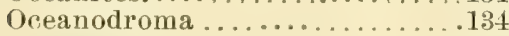

Ochthodromus ............... 101

Edemia................122, 123
Estrelata................... 134

Olor .............................

Onocrotalus .......................

Onychotes.....................

Oporornis ..............52,53

Oreortyx.................. 97

Oreoscoptes................41

Ornithion ................. 74

Ortalida .................. 95

Ortalis.................. 95

Ortygometra.................. .

Ortyx................... 97

Ossifraga .................. 134

Otus...................... 85

Oxyechus........................

Pagophila .........................

Pandion ...................90,93

Panyptila.................. 76

Parra (also Jacana)............114

Parula................... 52, 53

Parus..................... 63

Passer .................. . 61

Passerculus. .............64, 66

Passerella ..............6. 65, 66

Passerina ............... 66

Pediceetes. ............... 97

Pelecanus........124, 125, 126, 127

Pelidna ...............107, 108

Pelionetta .................. 1222

Perdix ................98, 115

Perisoreus .............. 71

Perissoglossa . . . . . . . . . . . 5.:

Petrochelidon.............. 57

Peucæa.................64, 66

Peucedramus................ 53

Phænopepla............... 5s

Phæthon .................. 128

Phæton.......................

Phainopepla ............42, 58

Phalænoptilus . ............ 5

Phalacrocorax .............. 126

Phalaropus.................. 103

Phaleris ..............137, 138

Philacte .................... 120

Philohela................107. 108

Philomachus................. 10s

Phobastia .................. 13t

Phøbetria . ............... 134

Phonicopterus............... 116

Phylloscopus .............. 42

Pica ...............

Picicorvus ................... 71

Picoides .................... 82

Picus .......................

Pinicola .................. 63

Pipilo................65,66

Pitangus................. it

Platalea...................... 110

Platea ...................... 110

Plectrophanes.........63, 66

Plegadis .................. 109 


\begin{tabular}{|c|c|}
\hline 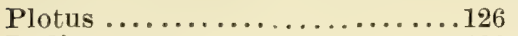 & Squatarola \\
\hline 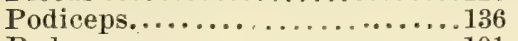 & Starnœenas ................ \\
\hline 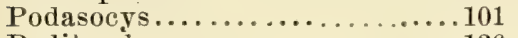 & Steganopus ................. 103 \\
\hline Podilymbus............. 136 & Stelgidopteryx $\ldots \ldots \ldots \ldots \ldots \ldots$ 57 \\
\hline Polioptila . . ........... 42, 72 & Stellula......... \\
\hline Porzana .................. 115 & Stercorarius ........... \\
\hline Polyborus ................ 90 & Sterna ................ \\
\hline Polysticta ..............122, 123 & Sternula ................... \\
\hline Poocætes .....................6.64 & Strepsilas..................... 102 \\
\hline Poocetes................... 66 & Strix $\ldots \ldots \ldots \ldots \ldots \ldots \ldots$ 84, 85 \\
\hline Poospiza.................. 64 & Sturnella $\ldots \ldots \ldots \ldots \ldots \ldots \ldots \ldots 69$ \\
\hline Porphyrio ................ 116 & Sturnus ................ 71 \\
\hline Priocella............... ..134 & Sula $\ldots \ldots \ldots \ldots \ldots \ldots \ldots$ \\
\hline Priofinus .................... 134 & 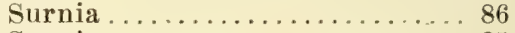 \\
\hline Procellaria ............. 134, 135 & Surnium \\
\hline Progne ... ................ 57 & Symphemia ............... \\
\hline Protonotaria .............52, 53 & Synthliborhamphus ......... \\
\hline Psaltriparus ................ 43 & Tachybaptes................. 136 \\
\hline Pseudogryphus. .............. 93 & Tachycineta ............... 57 \\
\hline Psilorhinus $\ldots \ldots \ldots \ldots \ldots \ldots \ldots 71$ & Tachypetes ............... \\
\hline Ptiliogonys ................. 58 & Tanagra $\ldots \ldots \ldots \ldots \ldots \ldots$ \\
\hline Ptilogonys .............58, 72 & Tantalops .................110 \\
\hline Ptycorhamphus...............137 & Tantalus .................... 110 \\
\hline Puffinus . . . . . . . . . . . . . . . . 134 & Telmatodytes ............. \\
\hline Pyranga................... & Tetrao ..................... \\
\hline Pyrocephalus ............... 74 & Thalassarche ............. \\
\hline Pyrrhula ............... 66 & Thalasseus................... \\
\hline Pyrrhuloxia $\ldots \ldots \ldots \ldots \ldots \ldots 65,66$ & Thalassidromas $\ldots \ldots \ldots \ldots \ldots \ldots 135$ \\
\hline Querquedula ...............121 & Thallasseus ................ 132 \\
\hline Quiscalus ...................70 & Thrasaëtus.................. 92 \\
\hline Rallus ..................113, 115 & Thrasyaëtus ................. 92 \\
\hline Recurvirostra............... 102 & Thryomanes ........................ 46 \\
\hline$\ldots \ldots \ldots, \ldots \ldots, 42$ & Thryothorus ............... 46 \\
\hline Rhodostethia ................ 131 & Tinnunculus $\ldots . . . \ldots \ldots \ldots \ldots . . . . .90$ \\
\hline Rhyacophilus . . . . . . . . . . . 108 & Totanus ........................... \\
\hline Rhynchofalco.............. 90 & Tringa $\ldots \ldots \ldots \ldots \ldots \ldots 10 \ldots$ \\
\hline Rhynchophanes............. 66 & Tringoides ..................... 108 \\
\hline Rhynchops ...............132 & Trochilus $\ldots \ldots \ldots \ldots \ldots$ \\
\hline Khynchopsitta............. 83 & Troglodytes ................. \\
\hline Rissa $\ldots \ldots \ldots \ldots \ldots \ldots \ldots \ldots \ldots \ldots . . .131$ & 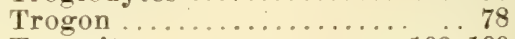 \\
\hline Rostrhamus . . . . . . . . . . . . 88 & Tryngites ............... 108, 109 \\
\hline Salpinctes ................ & Turdus...............40,41 \\
\hline 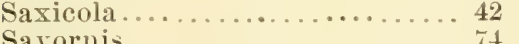 & Turtur............ \\
\hline Sayornis .................. & 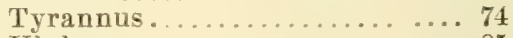 \\
\hline Scardafella ................ 94 & Ulula...$\ldots \ldots \ldots \ldots \ldots$ \\
\hline Schoeniclus ................ 107 & 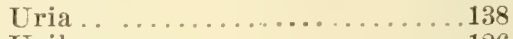 \\
\hline Scolecophagus .............. & Urile ........ \\
\hline colopax ................... & Urubitinga .............. \\
\hline Scops $\ldots \ldots \ldots \ldots \ldots \ldots \ldots \ldots \ldots \ldots$ & 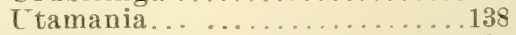 \\
\hline Seiurus ............... & 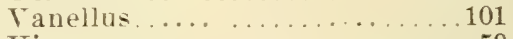 \\
\hline Selasphorus $\ldots \ldots \ldots \ldots \ldots \ldots$. . . & Tireo ........ \\
\hline $\begin{array}{l}\text { Setophaga. } \ldots \ldots \ldots \ldots \ldots \ldots .52,505 \\
\text { Sialia }\end{array}$ & Vireosylvia................ \\
\hline $\begin{array}{l}\text { Sialia } \\
\text { Sitta }\end{array}$ & Vultur .................... \\
\hline & Xanthocephalus. \\
\hline $\begin{array}{l}\text { Siurus ... } \\
\text { Somateria }\end{array}$ & 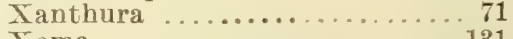 \\
\hline $\begin{array}{l}\text { Somateria } \\
\text { Spatula }\end{array}$ & Xema $\ldots . . . \ldots \ldots \ldots \ldots$ \\
\hline $\begin{array}{l}\text { Spatula ... } \\
\text { Speotyto }\end{array}$ & Xenopicus.. \\
\hline Speoty to .... & Zamelodia . \\
\hline $\begin{array}{l}\text { Epermophila } \\
\text { spheotyto... }\end{array}$ & Zenaida ... \\
\hline Spheotyto.... & Zenaidura.............. \\
\hline D & \\
\hline
\end{tabular}









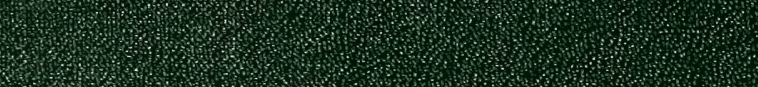

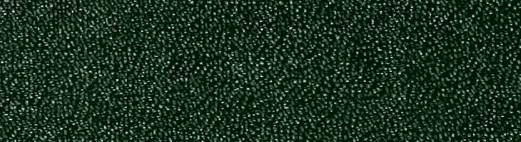

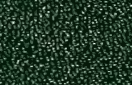

(x)

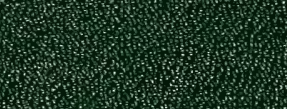

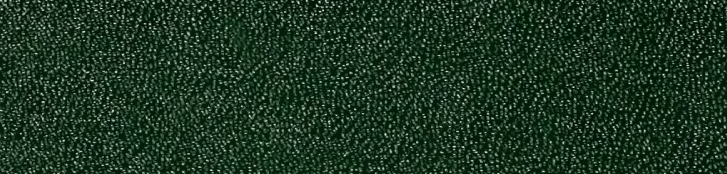

W

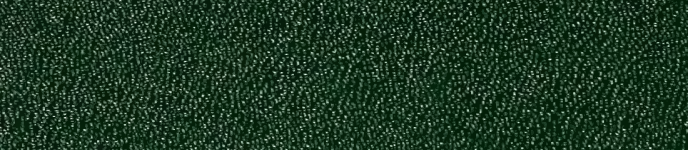

W(1)

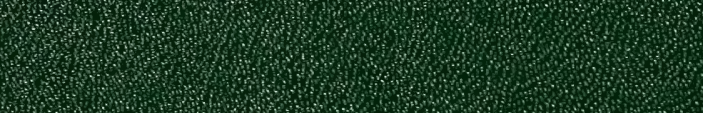

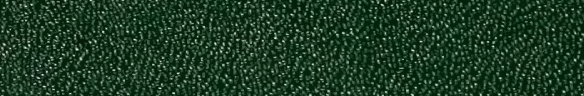

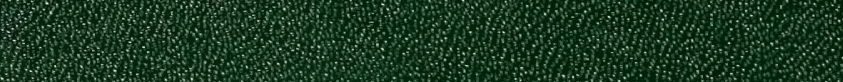

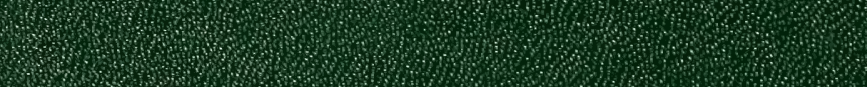
\begin{tabular}{|c|c|c|c|c|}
\hline & \\
\hline
\end{tabular}

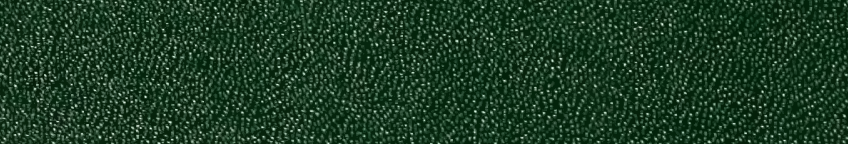

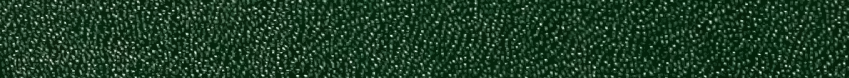
1.7.7. W.

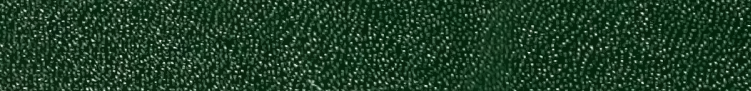
W.1.7. H. \begin{tabular}{|l|l|llll}
\hline & \\
\hline
\end{tabular}

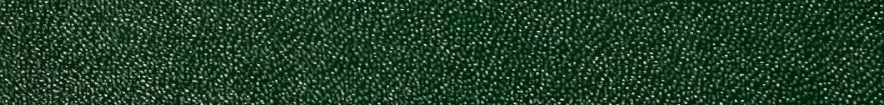
\begin{tabular}{|l}
\hline \\
\hline
\end{tabular} W

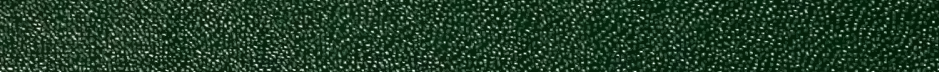

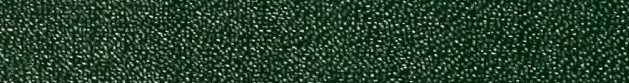

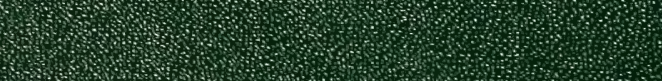

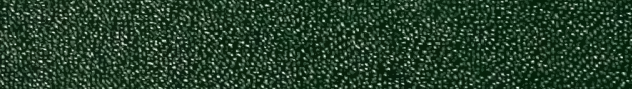

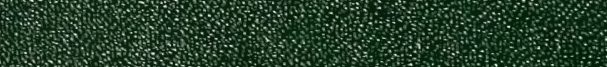
W W. 